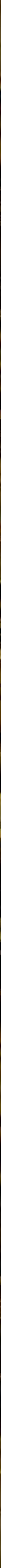




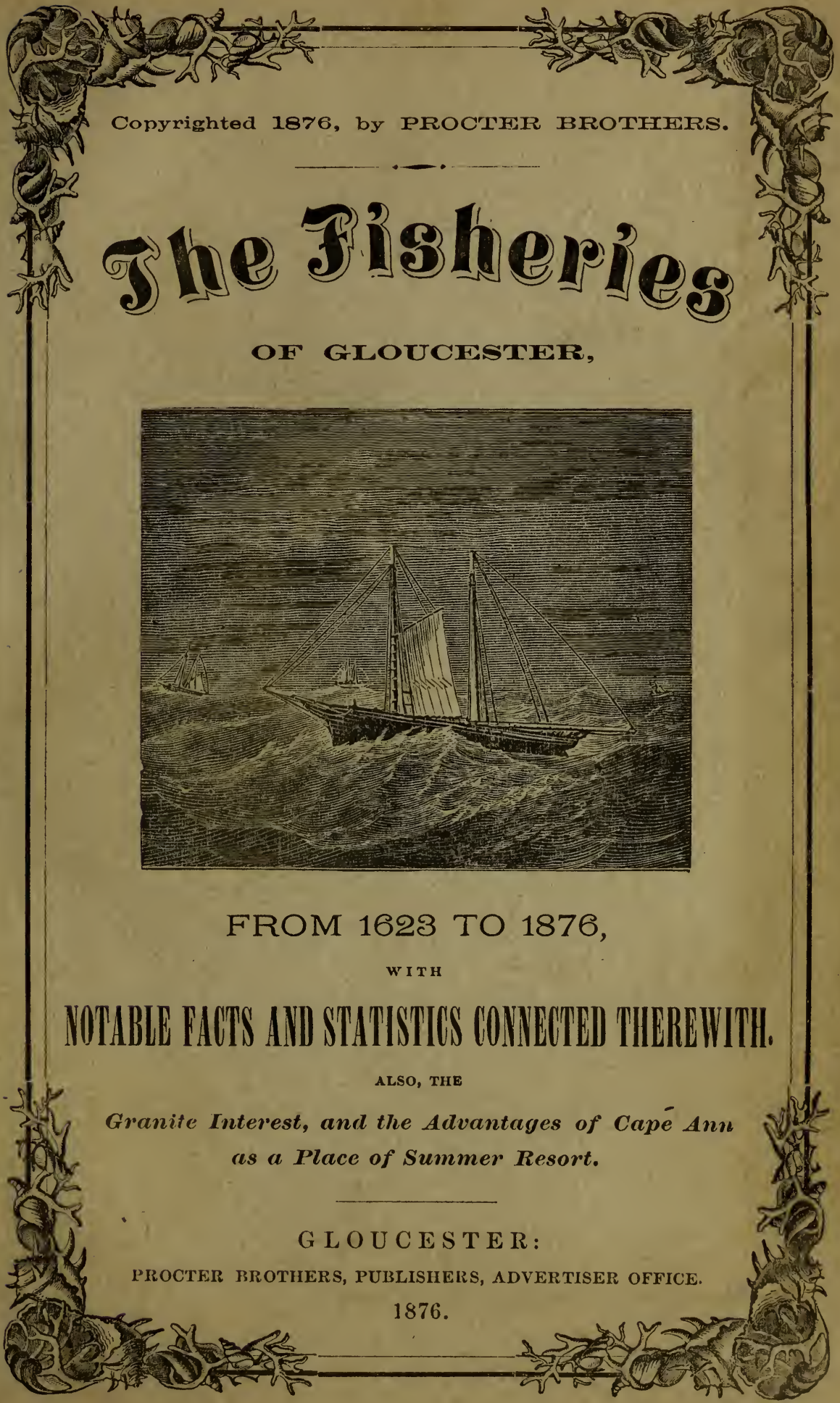





\section{THE}

\section{Fisheries of Gloucester}

FROM THE

\section{FIRST CATCH BY THE ENGLISH}

\section{N 1623}

To the Centennial Year, 1876.

GIVING AN ACCOUNT OF

THE SETTLEMENT OF THE TOWN ; DEVELOPMENT OF THE FISHING BUSINESS ; VARIOUS BRANCHES ; STATISTICS OF CATCH; MODELS OF VESSELS;

The Granite Interest; The Advantages of Cape Ann as a Place of Summer Resort, Etc., Etc.

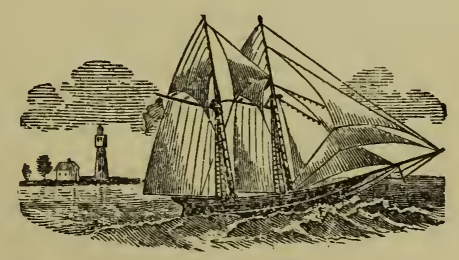

GLOUCESTER :

PROCTER BROTHERS, Publishers,

CAPE ANN ADVERTISER OFFICE. 
$\frac{Q}{207088}$

Dea.1.76 


\section{PREFACE.}

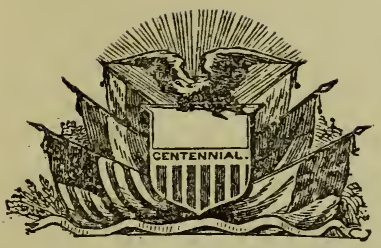

Is this centennial year of the nation, when all the world is to be represented at Philadelphia, our young city by the sea, through some of her leading citizens, felt a strong desire to add her tribute to the exhibition, and let the people know what she had been doing for a hundred years or more.

The Centennial fever was raging everywhere, and the symptoms were soon manifest in our community. Meetings were held, and it was determined that the fishing business, which Gloncester had pursued so long and clung to so tenaciously, through good seasons and poor, through sacrifices of life and property which are indeed appalling, should be represented. To this end a committee was appointed, and owing to their untiring zeal and labors there may be seen in the Gloucester department of the Agricultural Building at Philadelphia, a tank $23 \times 12$ feet, filled with water, in which correct models of the fishing fleet, of the olden time and of modern times, are afloat, illustrative of the various branches of the fisheries. A miniature wharf, of the present day, perfect in all its details, and a cob wharf of the olden time, a graving dock and marine railway, make into the tank, while crews of miniature model fishermen, clad in the garments peculiar to their avocation, impart animation to the scene, the whole giving a vivid idea of the manner in which the fisheries of Gloucester are pursued. About the tank may be seen specimens of the products of the fisheries, of fishing gear, cordage and various patented articles of merit used in the business, together with specimens of minerals, mosses, shells, coral, sea-corn, and other curious productions of old Neptune's garden at the bottom of the sea, brought in by the fishermen or gathered along our beaches.

In connection with this exhibition, this pamphlet has been prepared, giving a history of Gloucester and of her advancement in that 
branch of industry in which she has attained such a prominent position, that, in this Centennial year, she can safely challenge any port in the world to a comparison with her catch of fish, her clipper vessels, and the enterprise and daring with which the business is prosecuted. She stands to-day at the head of the fisheries, as headquarters for the purchasing of fish, from first hands, a fact which a walk about her wharves demonstrates to a certainty. The telegraph brings orders daily from all portions of the country, and the facilities for transportation are such as to warrant purchasers to send their orders direct to Gloucester. If another half-century witnesses such rapid growth and progress in this branch, as the past has developed, we may expect to see the shores of her outer harbor lined with wharves, the much talked of breakwater on Dog Bar completed, the marginal railroad in active operation, horse railroads around the Cape and throughout the city, her population doubled, and vacant lots on hillside and valley, covered with neat dwelling houses.

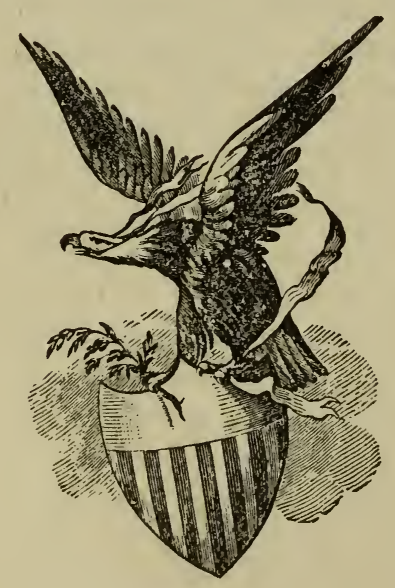




\section{GLOUCESTER AND HER FISHERIES.}

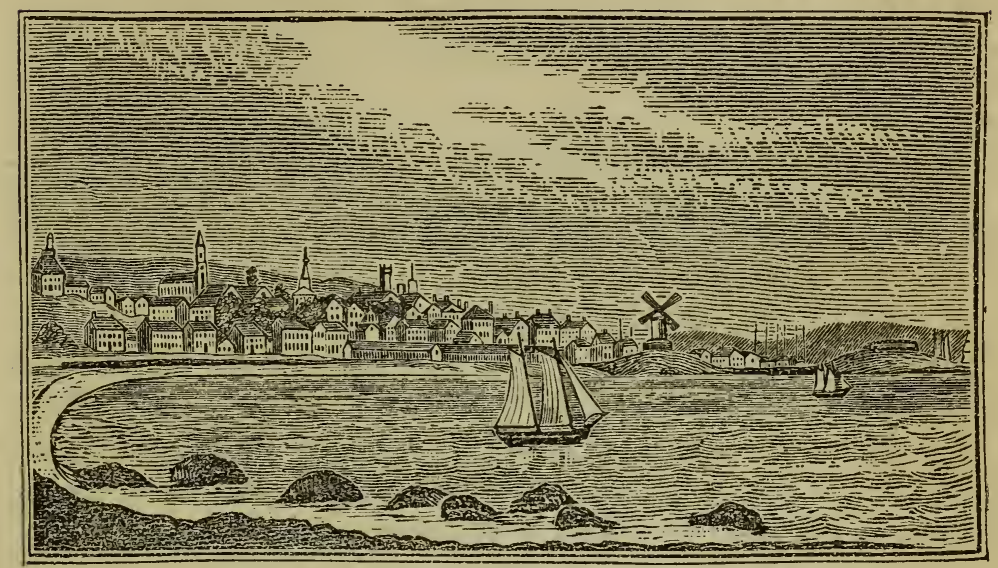

VIEW OF GLOUCESTER IN 1830.

\section{CHAPTER 1.}

Geological-Islands-First Occupation of Territory-Early Settlement-Growtit of Town-Division of Lands-Ship Building-Military Services, etc.

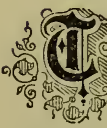

HE northern promontory of Massachusetts Bay, known as Cape Ann, on which the City of Gloucester is situated, is a headland of about five miles in average breadth and extending about nine miles from the main land into the Atlantic Ocean. Its geological features are remarkable, and, at first sight, strike every beholder with astonishment. The under-lying formation seems to be everywhere of solid granite, which rises to the surface over a considerable portion of the territory, and in several places is thrown up many feet above, forming rocky hills and extensive and precipitous ledges. Scattered thickly, too, all over the territory are boulders of every size, having, in many instances, such regularity of shape and vast magnitude as to entitle them to no mean rank as natural curiosities. In a few places these boulders are heaped together in immense masses, extending over large tracts of the surface, where the eye seeks in vain for signs of vegetation or even for soil to support it. These peculiar features of Cape Ann give a somewhat rugged and sterile aspect to the scenery, but this is amply compensated 
by the unrivalled attractions of beauty and sublimity which the ocean here presents.

Off the head of the Cape, and quite near the shore, lie three islands worthy of mention on account of some historical note; for they are the same islands, fronting "the fair headland Tragabigzanda," named the Three 'Turks' Heads by Capt. John Smith, in 1614. They are now known by other names, one of which, Thacher, perpetuates the memory of the first and most distressing shipwreck that ever happened on the Cape, by which, in August, 1635, about twenty persons, men, women and children, lost their lives at that island, upon which Mr. Anthony Thacher and his wife were thrown alive by the sea, and were the only survivors.

The first occupation of Cape Ann by people of the English race was in 1623, when a fishing vessel, sent by a company in England with a view to the establishment of a settlement somewhere on the soast, not being able to complete her lading at the usual fishing grounds on the coast of Maine, "the master thought good to pass into Mattachusetts Bay, to try whether that would yield him any." Here he succeeded; and, having completed his cargo, proceeded with the same to Spain; having left fourteen men " in the country at Cape Anne," for the purpose, without doubt, of beginning the work of the plantation projected by the English company. History refuses to gratify us with any further information concerning these men, but we know that, besides the pilgrims at Plymouth, the only other persons of European parentage they could then find within the present limits of Massachusetts were a few persons at Nantasket and a few others at Weymouth.

Early in the next year (1624) the same ship, commanded by the same master, and accompanied by another vessel of one hundred and forty tons, came again to Cape Ann, and, after an unsuccessful season's fishing, leturned to England, leaving now thirty-two men to remain at the plantation. Not discouraged by the ill success of this year the adventurers in England continued their efforts to establish a permanent colony on the shores of Cape Ann, and sent, in the next year, three vessels, one of which, of about forty tons, brought out "kine and other provisions." They also appointed a competent man, Roger Conant, to be its governor; but from various causes their enterprise came to an end this year and the plantation was broken up. MIr. Conant, with some of his companions, removed a few miles further west to Naumkeag, now Salem, where, soon after, "a new colony upon the old foundation," was established, which, in 


\section{DAVIS \& FEARS,}

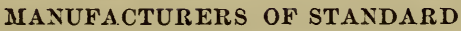

\section{Black and Yellow}
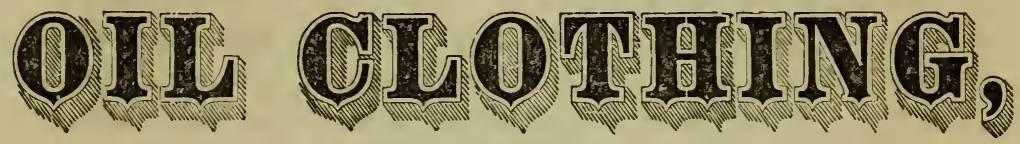

Lincoln and Cape Ann Sou' Westers,

\section{FANCY AND CAPE ANN LONG COATS,}

\section{(1) ש}

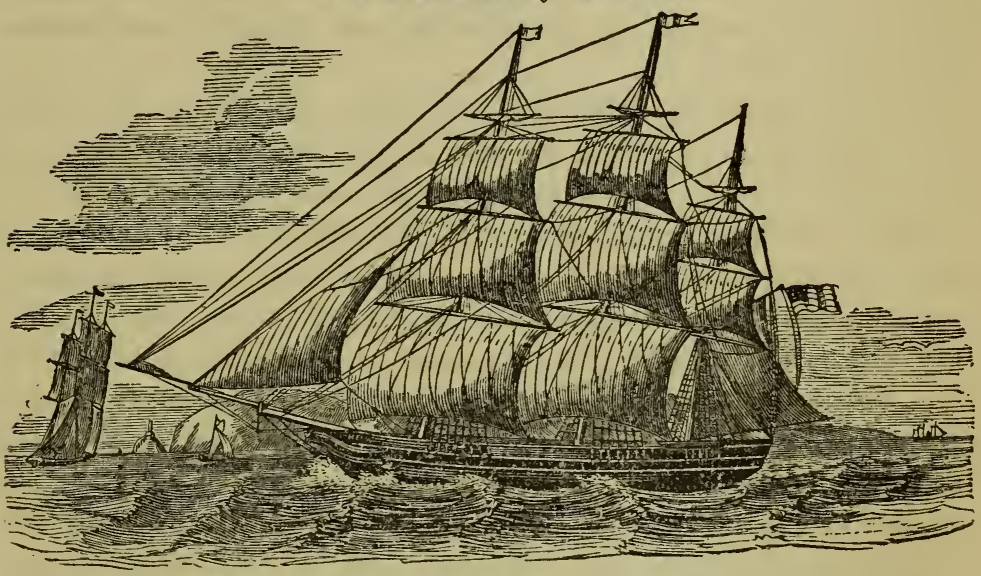

\section{OUR STANDARD BLACR OIL CLOIHING}

is the only genuine in the market, as we are the only parties having the patent process of mixing and applying the Black Preparation.

Also our YeCLOW is not excelled by any manufacturer in the country, being made from the best Cotton Cloth in the market, and using pure boiled LiNSEED OIL which is prepared expressly for us, we can warrant them perfect in every respect.

SEND FOR PRICE LIST. SAMPLES SENT IF REQUIRED.

Office and Manufactory, GLOUCESTER，（CAPE ANN,） MASS, 
a short time, became the great Colony of Massachusetts Bay. During these last two years the Plymouth people seem also to have carried on the fishing business at Cape Ann, having had, in 1625, two vessels engaged in it, but their efforts in this direction were also abandoned at the end of the last named year.

A spot on the westerly side of the principal harbor of the Cape, the largest tract of land on its borders fit for planting, has always been pointed at by tradition as the spot occupied by these first English occupants, and early records designate the place as "ffisherman's field." Here they dried their fish and gave some attention to the cultivation of the soil, receiving an occasional visit from the natives probably for purposes of trade; and we can scarcely doubt that they sometimes ascended the high ledge of rock on the shore, so marked a feature on the spot, to look down upon the settlement and the queerly-shaped and singularly-rigged vessels lying at anchor off their "stage" or wharf; and to enjoy a view of the beautiful sheet of water before them, embosomed as it then was in a girdle of the original forest.

How soon after the departure of Conant and his company Cape Ann became the residence of new settlers, it is impossible to tell. From a sermon of the last century it seems to have had inhabitants in 1633 , and there can be no doubt that fishing was "set forward, and some stages builded" as early as 1639. In 1642 the settlement had grown to such consequence by the arrival of Rev. Richard Blynman with several others from Plymouth Colony, and a few families from Salem, that, in May of that year, it was established to be a plantation and called Gloucester. The whole number of settlers to the close of 1650 was eighty-two, about one-third of whom remained in town and found here their final resting-place. Of a few of these, Babson, Bray, Day, Elwell, Haskell, Ingersol, Robinson, Sargent, and Somes, descendants continue at the present time.

Strange as it may seem, there is nothing to show that the first settlers of Gloucester were fishermen. A very few may have been engaged in that occupation, in a small way; but it is certain that almost all of them were employed on the land and not on the sea. Several of them were ship-carpenters, and one of these, William Stevens, was one of the most prominent of the settlers. He enjoyed some fame in his occupation before he came to New England, as the builder of the "Royal Merchant," a great ship of 600 tons, at London; and we know that he built a ship in Gloucester in 1661; and perhaps he built many others in the intervening years. Though it 


\section{CARTER'S}

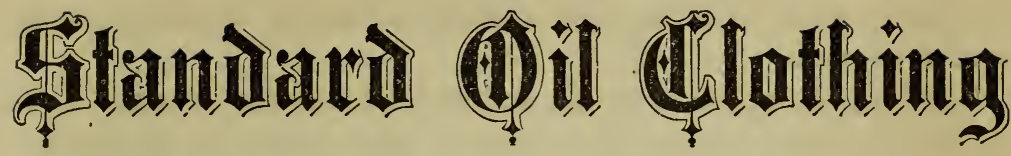

BLACK AND YELLOW.

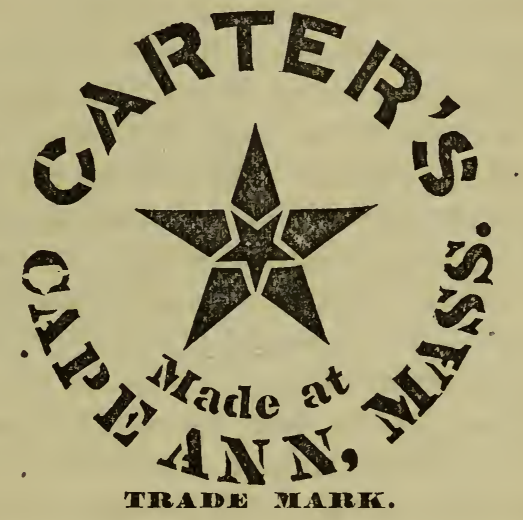

Having had a large and direct practical experience with the wants of the

\section{FISHERMEN AND SEAMEN,}

and having alevoted my whole time exclusively for years to the manufacture and improvement or

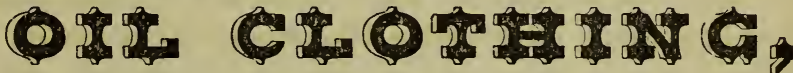

I claim a uperiority for my goods over all other manufacturers, and offer them to the trade as the

\section{BEST IN THE MARKET!}

For the protection of the trade, all my goods are sold direct from the Manufactory, and all orders should be addressed to

$$
\text { J. F. CARTER, }
$$

Manufacture and Sole Proprieter, GLOUCESTER, (CAPE ANN,) MASS. 
seems hardly possible that the town could have been less inviting for agricultural purposes, it is true that many of the first and later settlers took up such scattered tracks of clear land as they could find and derived their means of subsistence chiefly from the cultivation of the soil.

The Church organized by the first settlers was the nineteenth, in the order of formation, in the Colony of Massachusetts. It was not a happy body of Christians for a number of years. Dissensions prevailed during Mr. Blynman's ministry, and probably hastened, if they did not induce, his departure from the town. He remored to New London in 1650 , and was soon followed by many of the friends who had accompanied him to Cape Ann. The next settled minister was Rev. John Emerson, who came in 1660, and continued till his ministry was closed by death in 1700 . A second church was set off from the first in 1716, a third in 1728, a fourth in 1742 , and a fifth in 1754 , and corresponding divisions of the territory into parishes were also made. These parochial divisions have now no significance whatever, and the religious societies of the city at the present time are entirely independent of them.

The town had slow growth during the first half century of its existence. The whole number of men who became new settlers from 1651 to 1700 inclusive, was only eighty-seven, of whom about fifty became permanent settlers, and were residents of the town when they died. The names of some of them are numerously represented. by descendants, and it is not likely that Davis, Hodgkins, Lane, Lufkin, Norwood, Parsons, Pool and Rowe will cease to be the names of living persons on Cape Ann for many generations to come.

In 1700 there were about 700 inhabitants in the town. Nearly all of the tax-payers were commoners, that is, owners of all the territotory of the town not yet granted away. Except in one instance, to William Stevens, of fire hundred acres on the Chebacco side of Annisquam River, no very large grant had been made. Only one general grant in contiguous lots, that of 1688 , had been made to all the commoners; but the possession of the soil was constantly becoming a greater object of desire on account of the fine growth of timber with which it was covered, and it was this, without doubt, which led, in the first quarter of the eighteenth century, to the transfer of all the common land into the hands of the individual proprietors. 'The town hitherto had been of no importance as a maritime place; and, at the close of its first half century, all the property it held in vessels was comprised in six sloops, a boat, and a shallop. But a 


\section{RICHARDSON'S PATENT ICE CRUSHER.}

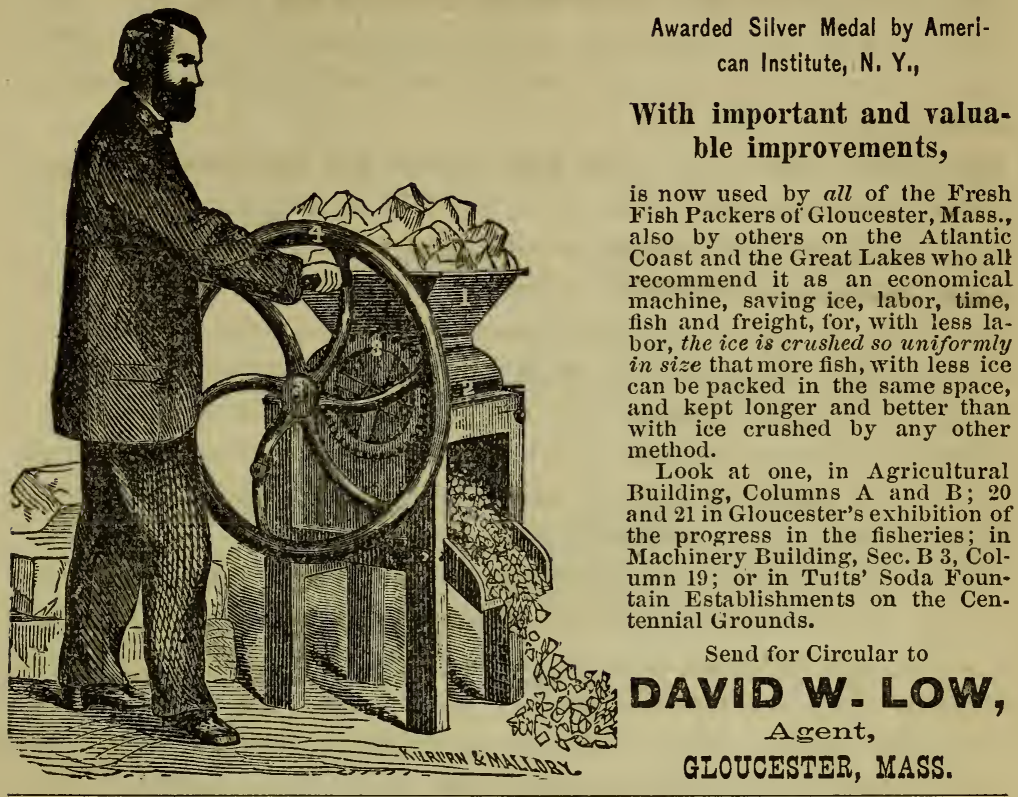

\section{RICHARDSON'S}

\section{- AND -}

\section{THE CENTENNIAL STEERERS}

CONTAINING MANY VALUABLE IMPROVEMENTS AND WELL WORTHY THE ATTENTION OF VESSEL OWNERS.

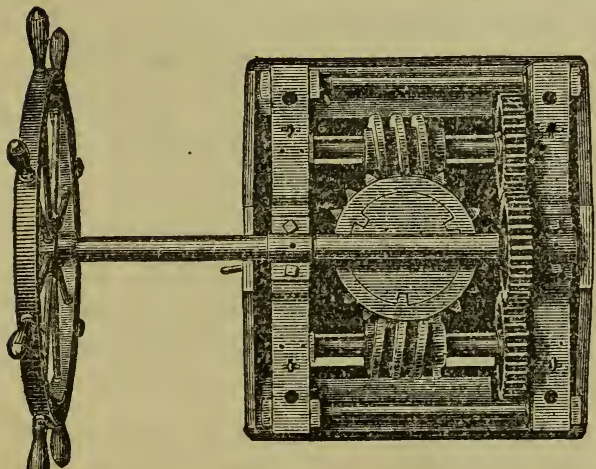

Four hundred of them are now in use on Fishing Vessels and YACHTS and have given perfect satisfaction. Clneapest and Hest visuals in vhe market.

In vessels using these Steerers, the wheel can be left in any position without securing it ly becket or other. wise. When blowing hard or in a heavy sea, the man at the wheel is in no danger of being injured or "thrown" as the action of the sea has no effect whatever upon the wheel. Nautical men will see the advantages of this in the coasting trade or in ressels short-handed.

It only requires five and a half revolutions of the wheel from hard up to hard down.

For full particulars and references send for pamphlet and price list to

\section{FRED. L. STACY, Agent,}

GLOUCESTER, MASS. 
season of great activity in ship-building now commenced. Ships and brigantines were built for Boston merchants, and a large number of sloops by people of the town for their own use. Many of the latter were used for the conveyance of wharf timber and other wood to Boston, and some were employed in the distant eastern fisheries; but there is nothing to show that Gloucester had, before 1700, a single vessel engaged in fishing as far east as Cape Sable. About this time, however, a vigorous pursuit of this business began, and with varying fortune it has been carried on to the present time. Out of the fisheries of the town grew a commerce with foreign countries-chiefly Spain, Portugal, and the West Indies at first, but finally with many other parts of the globe. This has ceased in late years, and it may be said that now Gloucester sends no merchandise across the seas, and with the exception of cargoes of salt for use in her fisheries, receives none. It does however carry on some trade with the British maritime provinces of North America.

This town has worthily borne its share of all public burthens. It sent about one-quarter part of all its men fit for military duty to suppress the great Indian rising of 1675 , and always contributed its full quota to the various military expeditions against the French and Indians in the subsequent years till the final reduction of Canada. In the memorable year of 1775 the people rose to the full magnitude of the great interests at stake; and with a prospect of suffering and gloom opening before them, declared that they would defend their liberties at the expense of all that was dear to them. So they had two companies in the battle of Bunker Hill, and sent altogether two hundred and twenty men in the first campaign of the war; and when Capt. Linzee, in the sloop-of-war Falcon, attacked the town in the same year, and attempted plunder and destruction, they boldly met his force and defeated and captured it: and when, after a year of great hardship and suffering, on the 24th of June, 1776 , the great question of a declaration of independence by Congress came before them at a large town-meeting called on purpose to consider it, they voted unanimously, if Congress should resolve upon the measure, to support them in it with their lives and fortunes. In ten days the Declaration was proclaimed to the world. The immortal document was read from all the pulpits of Gloucester, and copied into the records of the town. It was also copied into the records of the Third Parish, whose patriotic clerk, Thomas Marett, added-"May God Bless these Free and Independent States 


\title{
NEW ENGLAND FISH CO.,
}

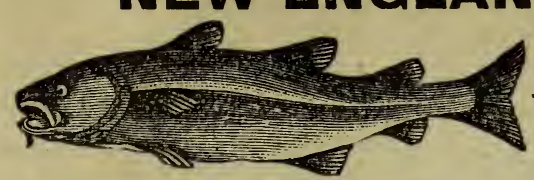

(Successors to A. W. Dodd, )

Wholesale Dealers in and Shippers of

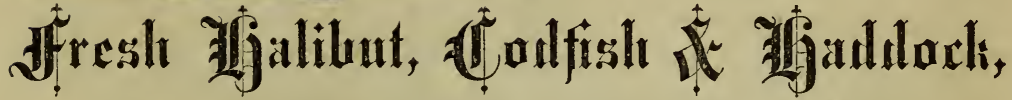
DODD'S WHARF, GLOUCESTER, MASS.

A. W. BRAY, Agent.

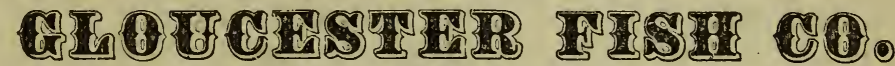

\author{
Wholesale Dealers aNd Shippers of
}

\section{Fresh Halibut,}

COD, HADDOCK,

Salt and Pickled Fish,

Fears" Wharf, Gloucester, Mass. W. H. OAKES, S. G. POOL,

W. H. GARDNER.

STOCIKBRIDGE \& CO., SHIPPERS OF

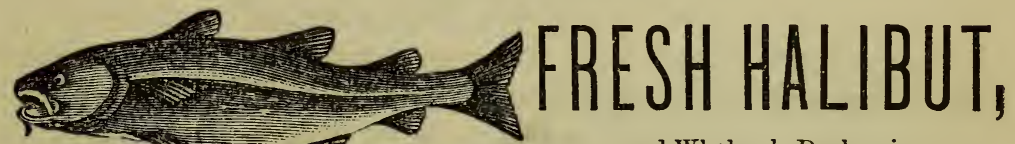
and Wholesale Dealers in

FRESH AND SALT FISH, STEAMBOAT WHARF, - - Foot of Duncan Street, \begin{tabular}{l} 
SETH STOCKBRIDGe, \\
D. I. ROBINSON. \\
\hline
\end{tabular}

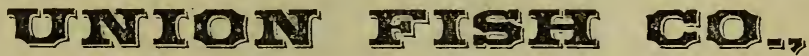

Wholesale Dealers and Shippers of

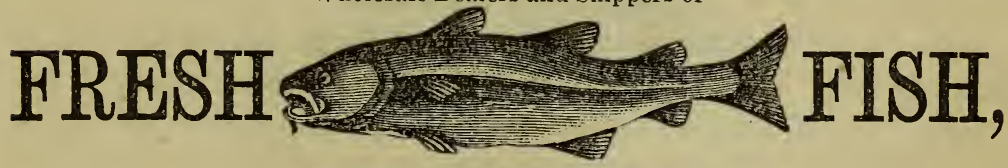

PARKHURST"S WHARF,

GLOUCESTER, MASS.

STONE; RICHARDS \& CO., ?

ANDREWS, RICH \& CO.,

WM. H. COOK, Agent and Treas.

P. H. PRIOR \& CO. 
Till Time shall be no more, with Liberty, Peace, and Safety. May America be Emanuel's Land. Amen and Amen."

The Revolutionary War brought great poverty and distress upon the people of the town. Their own soil afforded but a scanty supply of the necessaries of life, and they were obliged to send vessels to Virginia for the corn which they could not raise at home. Their commerce and fisheries were destroyed. The young and middleaged men fell victims to the war-some on the battle-field, some by sickness at camp, some in prison ships, and many in the depths of the ocean. More than one hundred went down at sea, in two privateer ships which were nerer heard from after their last departure from home ; and more than three hundred, about one-third of all the able-bodied men of the town, who had bravely entered into the contest for liberty, were no longer among the living when the great blessing of independence was secured. With this result achieved and a wide fieid for energy opened, the people resumed their former pursuits, and though the ante-revolutionary prosperity of the fisheries was not fully restored, they found in that branch and a successful foreign commerce sufficient returns to yield them all the substantial enjoyments of existence.

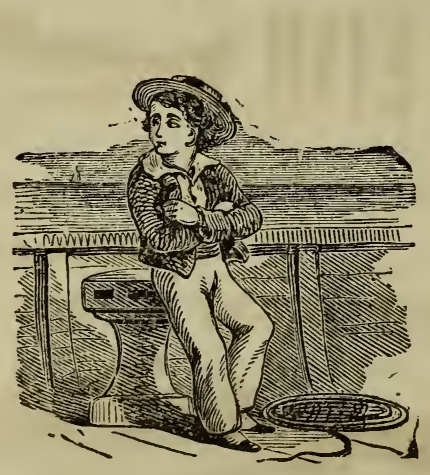




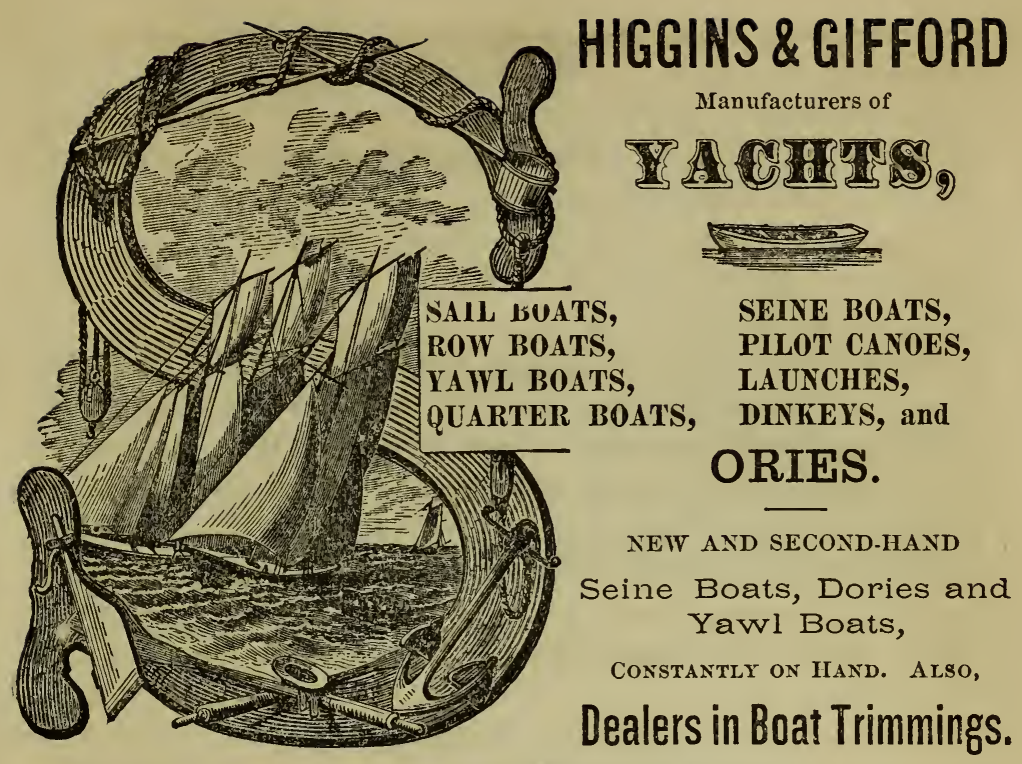

REFERENCES :-Most any fitter in Gloucester or New England.

P. O. Box, No. 130, GLOUCESTER, MASS. Send for Price List.

\section{WM. H. WONSON SON,}

WhOLESALE DEALERS IN AND CURERS OF

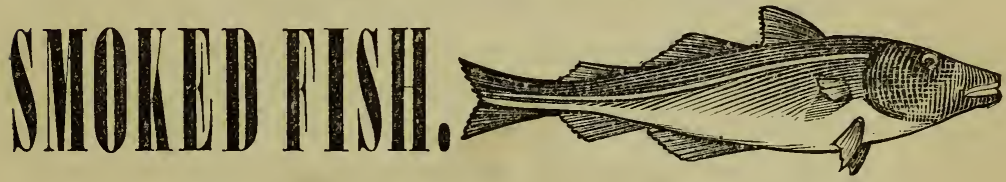

D11 Orders, by mail or otherwise, promptly attended to.

WM. H. WONSON,

CHAUCESTER, THASS.
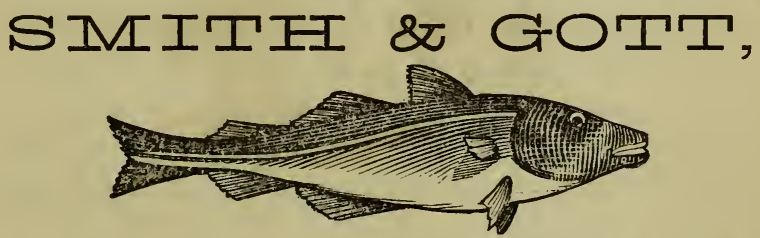

\section{DSholesale \$ish Dealers, 149 JACKSON STREET,}




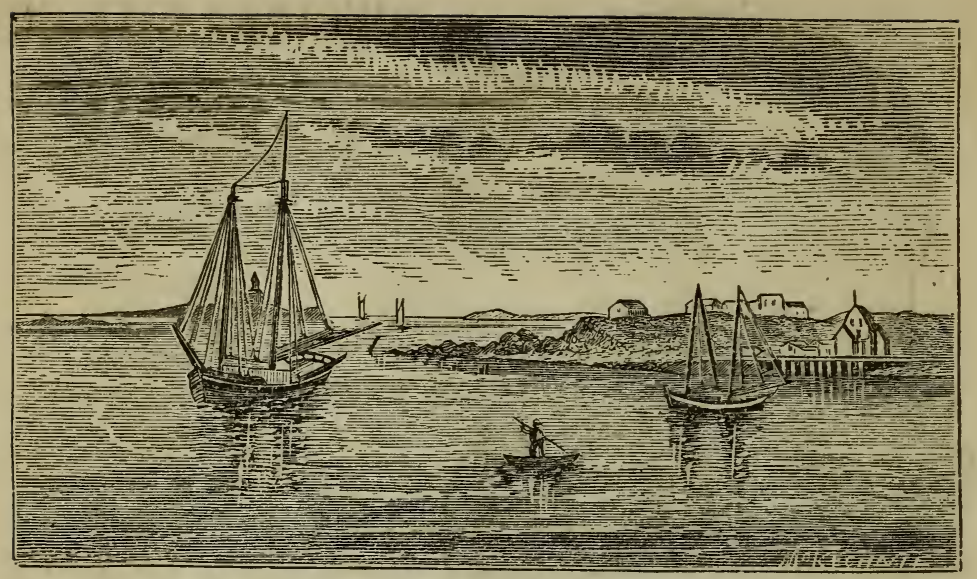

VIEW OF THE OLD FORT AND HARBOR IN 1837, WITH GRAND BANKER AND PINKEY AT ANCHOR.

\section{CHAPTER 2.}

Early Fisheries-New Settlement-Fishing Losses-Fisheries Previous to the Revolution.

Nature has marked out the principal employments to which the people who dwell on Cape Ann must resort for the means of subsistence. When they want bread they may, indeed, according as the demand for granite is great or small, get it from stone; but their chief reliance must be upon the occupations which call upon men to go down to the sea in ships. We have already seen that the first of the English race who occupied its shores were attracted by the advantages here offered for carrying on "the great sea business of fishing."

About twenty years before the period just alluded to, Gosnold, the first navigator known to have visited the coast, so "pestered his ships" with codfish, while lying off one of its capes, that that headland, from this circumstance, then received the name it has ever since borne-Cape Cod. Twelve years later (1614) another English captain, the famous John Smith, found about Monhegan, on the coast of Maine, "within a square of two or three leagues," the "strangest fish-pond" he ever saw ; where, in 1619, an English ship got a fare that yielded twenty-one hundred pounds in money; and where, the next year, several ships did even better than that. His account of the abundance of fish in those waters has even a touch of 


\section{GEORGE PERIINS \& SON,}

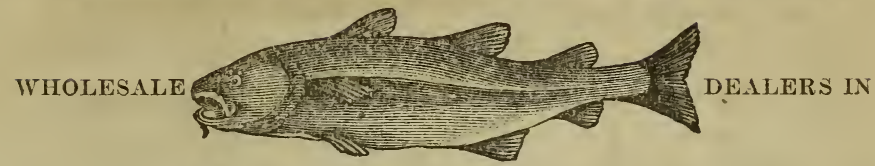

Dry Fish, Mackerel, Smoked Halibut, \& \& G

\section{JOSEPH O. PROCTER,}

INSPECTOP AND WHOLESALE DEALER IN

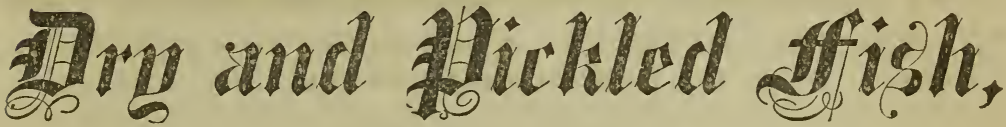 COMMERCIAL STREET,}

GIOUCOENTEIR, MASS.

PROCTE程, T黑QSK \& CO., WHOLESALE

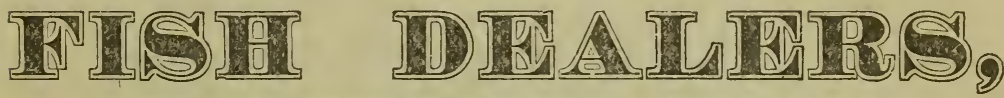
CLOUCESTER, WASS. And 505 N. 2d Street, - - ST, LOUIS.

GEO. P. TRIGG \& CO., WHOLESALE DEALERS IN

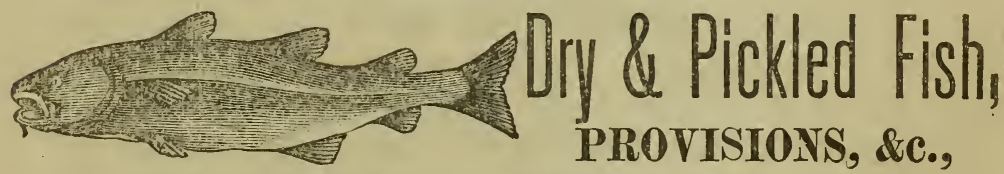

182 Duane street, NEW YORK, and GLOUCESTER, MASS.

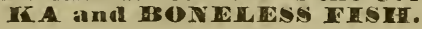


poetic rapture ; for he asks "what sport doth yield a more pleasing content, and less hurt or charge, than angling with a hook, and crossing the sweet air, from isle to isle, over the silent streams of a calm sea." From the date of Capt. Smith's royage English ships continued to resort to the coast of Maine for fish for several years, but their visits appear to have ceased soon after the settlement of the country. He tells us that thirty-five came in 1622 , the year before the voyage of the one that came first as far to the west as Cape Ann. These fishing voyages to the coast of Maine led to the establishment of several fishing plantations in that part of the country, and before 1640 it seems that at Pemaquid, Casco Bay, Cape Porpoise, Piscataqua, the Isles of Shoals, and perhaps at some other places, settlements had already been made, from one of which, in the six years from 1639 to 1645 , three thousand quintals of fish were exported. The Pilgrims at Plymouth do not appear to have engaged in fishing as a regular employment; but, in the first settlement of the Massachusetts Coiony, at Salem, we find preparations for fishing; for, in 1629, materials for the business were sent over, and mention is made of fishermen among the settlers ; and, as early as 1634, a merchant of the country was fishing with eight boats at Marblehead.

The last date brings us to notice a new settlement on our own shores, which was made in 1633 ; but no facts authorize us to say that the settlers were fishermen, or, indeed, what their employments were. The lapse of six years, however, again connects our territory with fishing occupations, and brings us to a proper starting point for a brief historical sketch of the fisheries of Gloucester.

By an act of the General Court, passed May 22, 1639, it was ordered that a fishing plantation should be begun at Cape Ann, with certain privileges and exemptions, for the encouragement of $\mathrm{Mr}$. Maurice Thomson, merchant of London, and others, to promote the fishing trade. To what extent Mr. Thomson availed himself of the encouragement here offered, no one now can tell, and if it were not that the Gloucester Records contain one single reference to the "parcell of land where Mr. Tomson's frame stood," there would exist nothing to show that he ever even commenced the enterprise. This "frame" stood, it is supposed, on what was afterwards called Duncan's Point, so named from Peter Duncan, a merchant, who owned the place and carried on a small trade there about 1662 . It is worthy of note that a steamer now leaves this very spot daily, laden with the products of the Gloucester fisheries to be distributed 


\section{Established 1849.}

\section{JoHn Pew \& Son,}

Producers of and Wholesale Dealers in
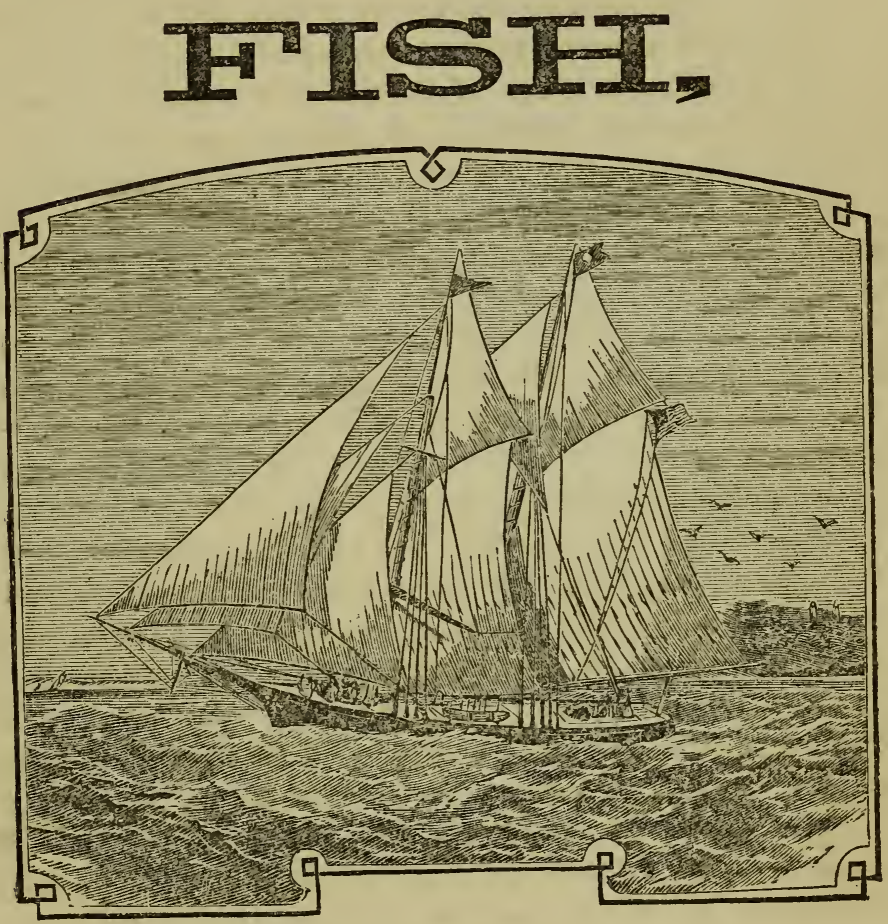

And Importers of

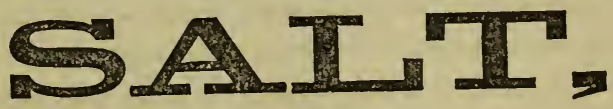

83 Spring Street, Gloucester, Mass.

JOHN PEW.

CHAS. H. PEW.
JOHN J. PEW. 
all over this vast country. It seems probable that Mr. Thomson, or some one else, did something more than erect a frame about the time the act was passed for his encouragement, for a writer of that period who was in the country in 1639 , mentions Cape Ann as a place "where fishing is set forward, and some stages builded;" and another early writer calls "Cape Ann a place of fishing; being peopled with fishermen till the Reverend Mr. Richard Blindman came." Of the company who came with him, and of other settlers who came about the same time, it does not appear that any engaged in the fishing business. It is certain that nearly if not all of them sought the most favorable spots for agriculture they could find, though it is quite probable that a few, who were located around the harbor, may have engaged to a very limited extent in shore fishing in small boats. In a case of litigation, in 1651 , about a piece of a net, mention is made of "the bote and voyg;" and about that time there appears to have been a fishing stage at Annisquam. A few years later Peter Duncan carried on a small trade at the Point, in the Harbor, where it is supposed that Mr. Thomson erected a building or a frame for the purposes of his fishery in 1639 , and, in company with others, owned a shallop. One man, in 1663, agreed to pay a debt of fifty pounds in "good merchantable fish and mackerel," and at this time we find "fish and mackerel" among the articles in which the salary of the minister was to be paid ; but not till many years after the settlement of the town can any evidence be found that a ressel of sufficient size to resort to distant fishing banks was owned in it. In two instances, in 1680, a sloop is found as part of the property of deceased settlers, and, in 1693, a tax-list on record at the State House in Boston, shows that all the personal estate of this description, then held by the people of Gloucester, was composed of six sloops, a shallop and a boat; and one or more of these, there is reason to suppose, was employed in wood-coasting. In 1695 the sons of Jeffrey Parsons had a fishing stage at Fisherman's Field, and one of them, who died in 1714, had one third of a fishing vessel, one half a shallop, and one half of an open sloop, all valued at £54; and another, who died in 1722, had three "scooners," part of two sloops, and shop goods and stores for fishing. At the last named date this business seems to have become firmly established in the town, though to what extent it was pursued can be a matter of conjecture only; but it seems quite certain that persons were engaged in it at the Harbor and at Annisquam,- -at the latter place more extensively, perhaps, than at the former, for one merchant, whose vessels sailed from 'Squam River, died in 1734, lear- 


\section{$J_{a s} G_{1} T_{12 r} \& B 0_{11}$}

WHOLESALE DEALERS IN

DRY AND PICKLED

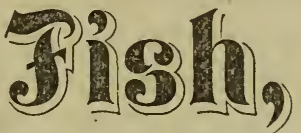

MACKEREI

AND

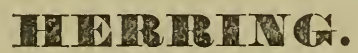

Prime SMOKED HALIBUT,

OF OUR OWN CURING,

A SPEUIALTY.

All orders from any part of the country promptly attended to at the lowest market price the day the order is receired.

SEND FOR PRICE LIST.

We fit out sixteen vessels and therefore obtain our fish from first hands.

P. S. The accompanying cut represents our fitting-out and curing establishment at GLOUCESTER, MASS.

DANEG G. TATEE.

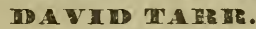

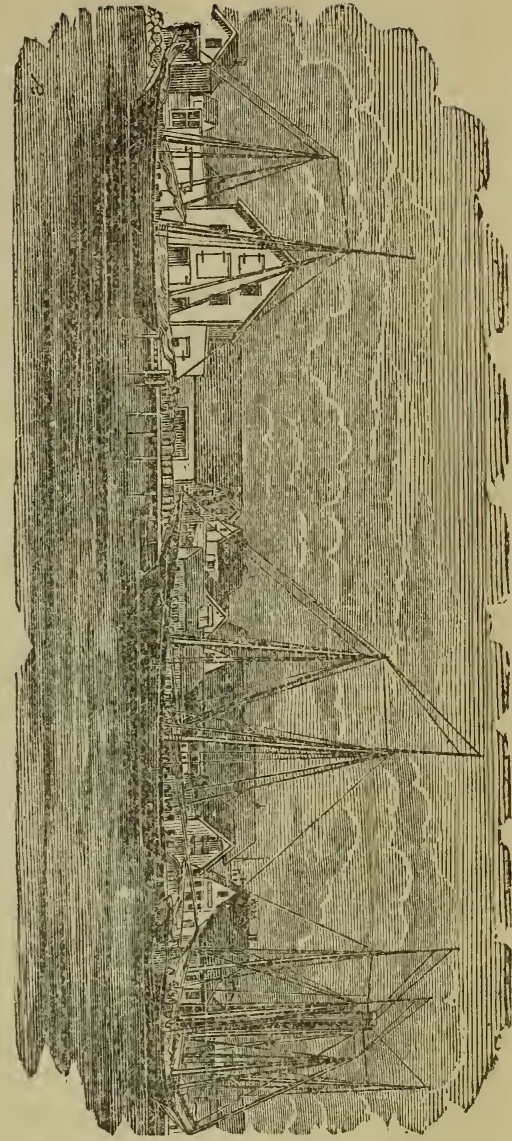

STI I

CURERS OF AND DEALERS IN

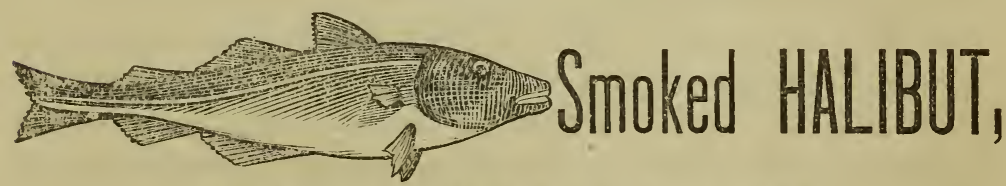

DRY and PICKLED FISH,

-ALSO,-

BONELESS and PREPARED FISH.

GHOUCHETER, MLAS. 
ing six schooners, a wharf and fishing-room at Canso, and a large amount of other property.

A more extensive maritime business in another branch had, however, been commenced in the carly part of the eighteenth century. A portion of the wood land of the Cape was then divided and many vessels were built in the town and used in the transportation of this article to Boston. There seems to be good ground for believing that as many as fifty sloops must have been engaged in it at one time; but it was a trade that must necessarily be of short duration, and finally other employments for the vessels must be sought. Fishing was, of course, the only resource, and we find, before 1720 , several sloops engaged in the distant fisheries. As early as 1711 certainly our fishermen began to resort to Cape Sable, and in 1716 mention is made of a "scooner" employed in fishing there:-the same one perhaps, the first of her class, that was built and owned by Capt. Andrew Robinson, a noted fishing captain who invented the rig of that class of vessels. This man is said to have been so industrious on the banks, when fish were plenty, that he would not leave his place on deck even to eat; but when he was hungry he had a ship-biscuit brought to him which he contrived to eat by working it round in his mouth with his teeth and lips, while his hands were attending to the hook and line. During these first years of the fishery the men were greatly annoyed by the French and Indians, and some were killed; but the business was rendered most discouraging by the havoc of shipwreck. The year 1716 is a year memorable in the annals of the town for the first sad and sweeping calamity of the kind, which has so often since shronded it in mourning. On this mournful occasion, five vessels, comprising, upon a reasonable supposition, not less than one-tenth part of all the tonnage of the town, were wholly lost in that year on a fishing voyage to Cape Sable; and about twenty men, a fifteenth part, probably, of all the male citizens of the place, perished by the catastrophe.

The history of the Gloucester fishery from this time to the Revolutionary War may be briefly related. The vessels with which the business was first carried on were the sloops built in the town. A few schooners were added about 1720 , and probably soon became the favorite class of vessels for this business. Many of them were of the burthen of fifty tons or more, and were therefore suitable for royages to the Grand Bank and other distant fishing grounds, and for employment in coastwise and foreign voyages in the winter season. They were of a peculiar model, which prevailed about a hun- 
SEIVALL, DAY\& CO, Manufacturers of

fordage \& Aakmoa.

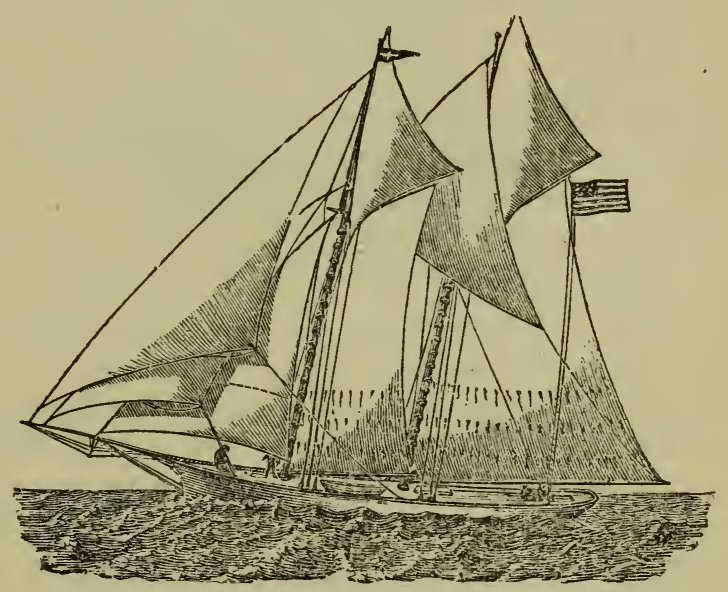

SPECIAE ATtention GTUEN TO

FISHERMEN'S OUTFITS, CABLES,

Net Rope, Trawl Lines, dec, de.

GANGS OF RIGGING made to order at Short Notice.

83 \& 85 Commercial Street,

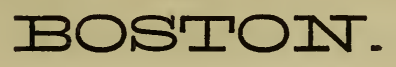


dred years. The following is an exact representation of the model and rig of the "old banker," one of which appears in the tank at the Gloncester department of the Centennial Exhibition at Philadelphia.

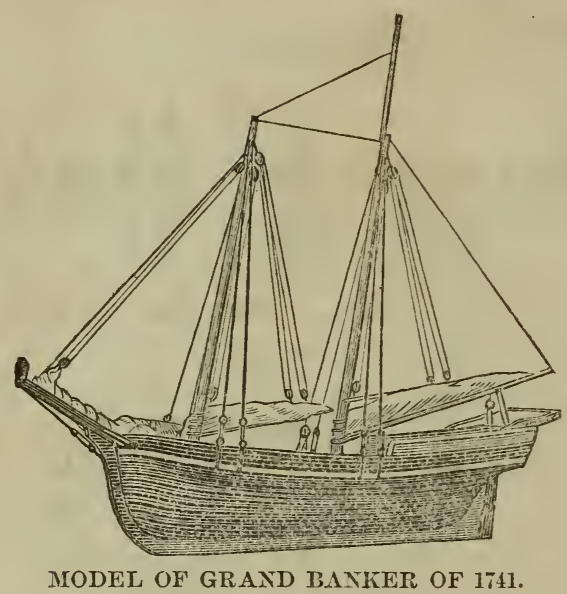

About seventy of these schooners were owned in Gloucester in 1741 , and nearly all of them were probably engaged in the Grand Bank fishery. In the fishing voyages, it was the custom for the men to go, as it was called, "on their own hook:" that is, an account was kept of the fish caught by each man; and, at the end of the voyage, the proceeds were distributed accordingly. 'The reason for' such a practice is sufficiently apparent in the account of a seasons' work by one crew on the Grand Bank in 1757. In that year, the Sch'r "Abigail," Capt. Paul Hughes, made three trips in about six months, and fished, in all, sixty-seven days, with the following result as to the number of codfish caught by each one of her crew of six men: Paul Hughes, 6643 ; B. Foster, 5000 ; Job Galloway, 4244 ; Nathaniel Day, 3929 ; Rufus Stacy, 3784; William Smith, 3435.

Notwithstanding the discouragements of the twenty years immediately preceding the reduction of Canada, growing out of the war's of that period, and occasional losses by shipwreck, there was no abatement of the energy with which the people of the town pursued the fishery. During that time it became the basis of a considerable foreign trade which was not only profitable to the merchants, but beneficial to the fishermen in giving them winter employment. In the latter years of the period now under consideration, we find Gloucester vessels making voyages to Cadiz, Bilbao, Lisbon, and different 


\section{SMITH \& BURNHAM,}

WHOLESALE DEALERS IY

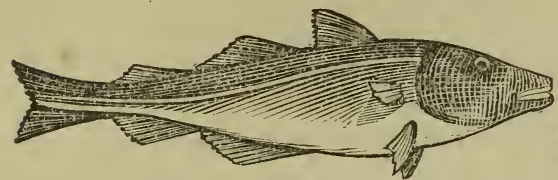

DRY, PICKLED

AND

\section{SMOKED FISH,}

Jos. Friend's Wharf, GLOUCESTER, MASS.

H. C. SMrti, , AOs Especial attention given to putting up Boneless Corl, Tongues E. K. Burnitan, $\}$ and sounis, Mackerel, \&c.

Iㅁ, W. TIOIMIANS,

TVHOIESAIE

Dealer, Shipper \& Exporter of Fish,

Also IMPORTER OF AND IVIIOLESALE DEALER IN

MOLASSES AND TEAS, GILBERT'S WHARF, - GLOUCESTER, MASS,

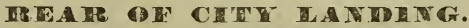

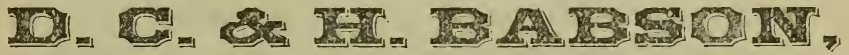
Receivers and Wholesale Dealers in

DRY and PICKLED
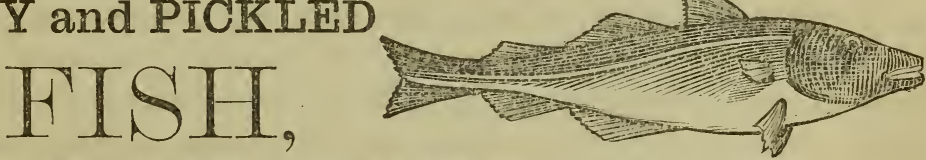

Fish Oils and rishing Outfits,

ORDEIRS SOLICITED AND

PROMPTLY FILLED.

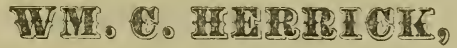
Wholesale Dealer in

FRESII AII PICKIDI IISI,

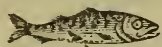

AND OILS.

Wharf at ROCKY NECK.

P. O. Address,

East Gloncester, Mass.
Gloucester, Inass. HENRY W. MEARS,

Manufacturer of Best Quality खी

TRAWL LINES,

G A NGING, \&c.,

\section{ESSEX, MASS.}

Orders by mail will receire prompt attention. 
ports in the West Indies; besides which it had also become common for them to make trading voyages in the Winter season to Virginia.

The peace of 1763 secured to our people unmolested use of the fishing grounds, and, from this time to the Revolution, they carried on the business with energy and success ; though one of those terrible misfortunes that shocks a whole community, and brings unutterable sorrow to many private bosoms, occurred in the meantime and cast its sad gloom over the town. In March, 1766, nineteen vessels sailed for the Grand Bank, and, while on the passage thither, were met by a violent storm, which wrecked and scattered the fleet, and sent many to the bottom. 'Two were cast away at Nova Scotia; seven foundered at sea, with all on board; and several of the others were so much disabled that they were obliged to return. The number of men lost by these shipwrecks is not known, but it was not probably less than forty.

We know but little of the relative importance of the Bank and shore fisheries at this time; but it seems that the latter were almost wholly confined to Sandy Bay and the coves on the outside of the Cape, while the chief seat of the former was at the Harbor. From such information as can be obtained, it appears that from 1770 to -1775 , between seventy and eighty schooners, of an average value of one thousand dollars, resorted yearly to the Grand Bank for cod; and about seventy boats fished for cod and hake and pollock on the ledges near our own coast. The business yielded a scanty support to the fishermen, and, as a class, they were poor ; though then, as in more recent times, some who began at the hook and line rose to be the most prominent and successful among the merchants who carried it on. No means exist for ascertaining the average annual earnings of the fishermen; but the accounts of a single schooner for 1773 are preserved, and show the product of her two trips to the Banks to have been 550 1-2 quintals of fish, which sold for $£ 302.9 \mathrm{~s}$, , or a little more than one thousand dollars in silver money. Supposing the number of the crew to have been six, and deducting the expenses and the vessel's part, and the bill for necessary supplies to the family of the poor fisherman while absent, it will be seen that there could have remained little or no surplus of his season's work, and that want must soon have compelled him to hurry away again once more upon the waters, as a sailor in the foreign or coastwise trade of the town.

Such is a brief historical sketch of the Gloucester fisheries down to the beginning of the Revolutionary war, at which time the town 


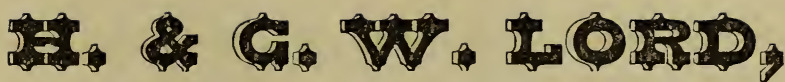

MANUFACTURERS OF

\section{NETS, SEINES and TWINE,}

No. 111 COMMERCIAL STREET,

\section{BOSTON.}

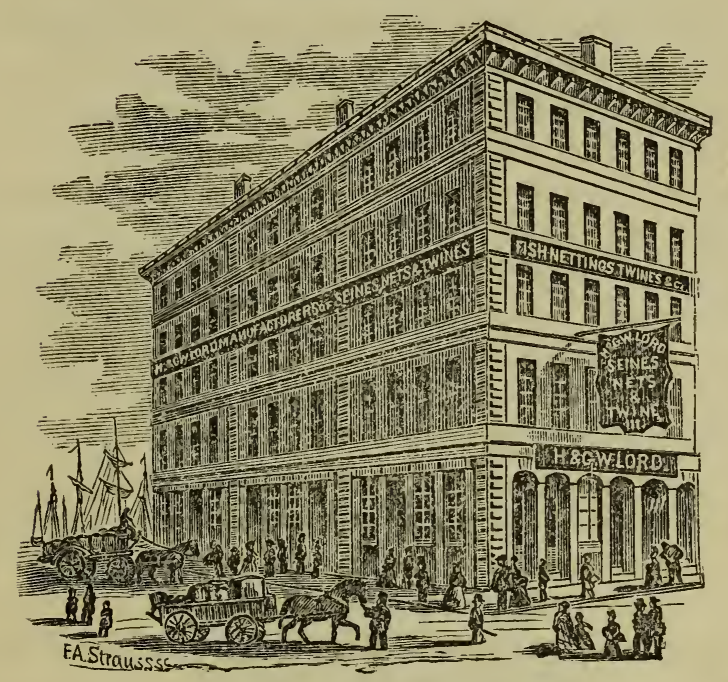

\section{FISHERMEN AND OUTFITTERS.}

MACKEREL SEINE NETTING made from Hadley Tuine.

We keep in our stock but one grade of POGIE SEINE TWINE and NET$\boldsymbol{T I N G}$, and that the very best manufactured in the country, without regard to cost.

PURSE MACKEREL SEINES, fitted complete, ready for the water, of best material, at moderate cost.

POUNDS, WEIRS, TRAT'S, SHORE AUd MINNOW SEINES ANd NETS.

LINEN GILL NETS made from Knox Linen Twine.

Patent and Seine Twine, Maitre Cord, Hemp and steam-tarred Manilla Seine Rope, Russia Purse Line, Spooner's Whale Line, Oak and Cedar Buoys, Seine Rings, Leads, \&c., \&c.,

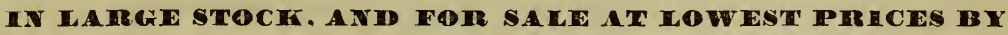

H. \& G. W. LORD,

111 Commercial St., BOSTON. 
had risen to be the second in New England in this important business, in which Marblehead took the lead, and was but slightly in advance of our own town. To sum it up in a few words it may be stated that in the fisheries of the town there were then engaged at least one hundred and fifty schooners and boats, aggregating four thousand eight hundred tons, and employing six hundred men. The yearly product of dried fish may be estimated at aboit forty-eight thonsand quintals, the value of which did not vary much either way from one hundred thousand dollars.

During the Revolntionary War the fishing schooners could not be employed for the business in which they had been previonsly engaged. Several were converted into privateers, a few rotted at the wharves, and some were preserved till peace again made it safe to engage in the Grand Bank fishery. A few small boats fished along the shores, but their product was of inconsiderable amount, and small as it was, probably exceeded the limited demand for home consumption. The boats used in this shore fishery were called Chebacco

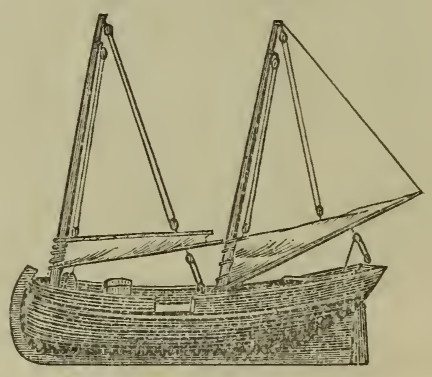

MODEL OF CHEBACCO BOAT.

boats, from the name of the place where they were built-a part of Ipswich, now the town of Essex. The name has a striking similarity to that of a small ressel mentioned in the French marine dictionaries-the chabek; but there is no doubt that our Chebacco boats - derived their appellation as here stated; and it is quite probable that in rig and model they were peculiar to Cape Ann and were first used in its waters. Like the "old Bankers," they have now entirely disappeared. 


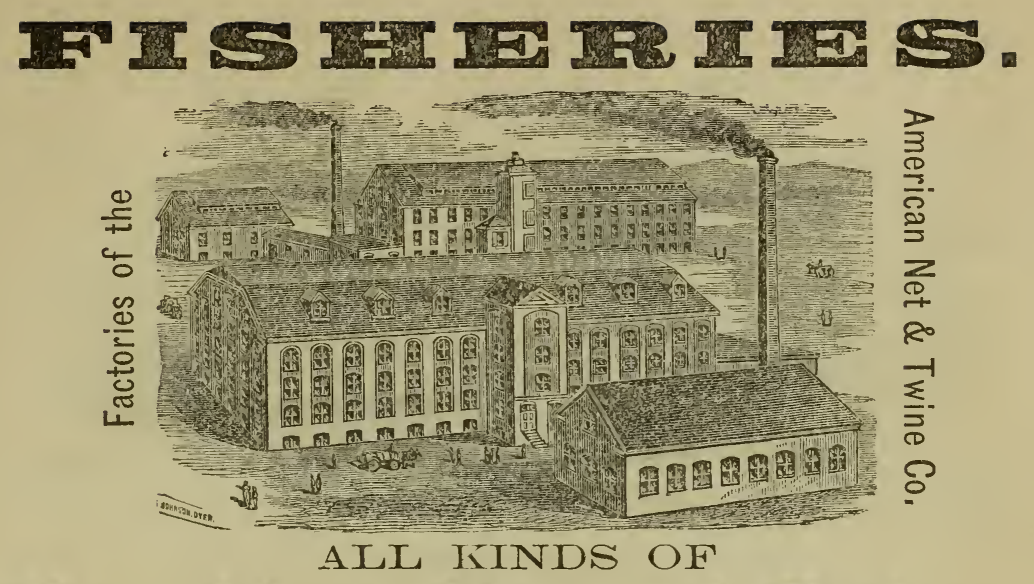

Nets, Seines, Lines and Twires, Suited to the Fisheries of the Continent, manufactured by the

\section{AMERICAN NET \& TWINE C0.,} 43 Commercial Street, - - BOSTON, MASS.

\section{GRIEFIN EROS.,}

\section{EASTPORT, MAINE,}

Commission Merchants,

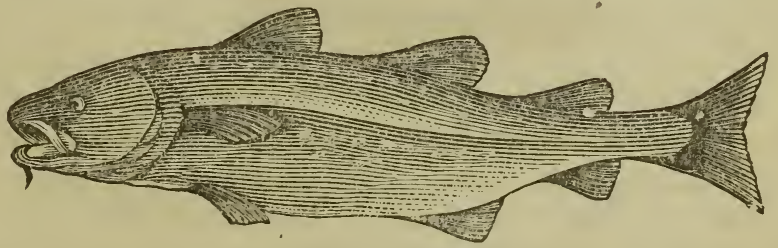

AND DEALERS IN

\section{FISH, FISH OILS \& FISH GUANO,}

AND CURERS OF THE WORLD RENOWNED

\section{"FINMAN HADDIES" and YARMMUTH BLOATERS.}

$$
\text { ALso, }
$$

Manufacturers of the Original Cape Ann Oil Clothing.

Factories at $\left\{\begin{array}{l}\text { FASTPORT, MAINH. } \\ \text { CAMPOBELIO, N. B. }\end{array}\right.$ 


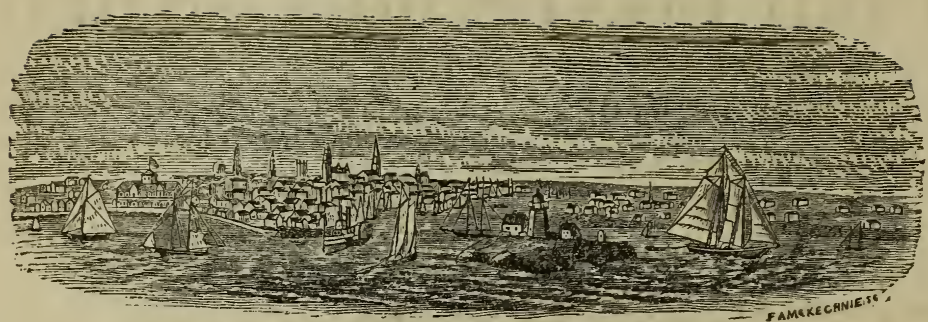

CITY OF GLOUCESTER, 1876.

CHAPTER 3.

Decline of the Bank Fishery-Fisming Company-Resumption of Bank Trips-Siore Fishery-Mackerel Fishery, Etc.

On the resumption of the Bank fishery, after the war, it appears from one statement that sixty vessels resorted thither from Gloucester; but the merchants of the town soon found a more profitable employment in foreign commerce, and this branch of the fishery rapidly declined till 1804, when we find that the whole number of vessels over thirty tons engaged in the fisheries of the town was only eight: and this falling-off in the particular branch here mentioned is fully explained by the fact, that all the traditions of the business report that the average earnings of the Bank fishermen were so small, that they were kept in a condition of poverty. Seeing this decadence, and stimulated in some degree perhaps by encouragement from the general government, in the way of bounty, a few publicspirited citizens attempted to put new vigor into the business by the organization of a fishing company with an authorized capital of fifty thousand dollars. This company began operations in 1819 , by fitting out seven schooners, but it soon found that a business which private capital avoided could hardly be expected to yield profit, even to the best corporation management; and, at the end of the third year, the enterprise came to an end, with a loss of a considerable portion of the capital invested in it, - a result which seemed to ex. tinguish all hope of prosperity from the pursuit of this branch of industry. In 1820 the U.S. Census showed that the population of the town had increased but twenty per cent. in thirty years, and, with the total extinction of its Grand Bank fishery, few entertained 
B. GRIFFIN \& SON,

Wholesale Dealer's in

\section{FISH BOXES}

OF ALL KINDS,

IN SHOOK OR MADE UP.

Large Quantities constantly on hand.

42 Front Street,

GLOUCASTER, MASS.
JOSEPH PARSONS,

Manufacturer of

OIL CLOTHING,

AND

Fishermen's Furnishing Goods,

Water St., East Gloucester.

OII, CLOTHING at Wholesale and Retail.

Orders from all parts of the Country promptly attended to.

Gloucester Fire Insurance Co.

\section{CLOUCESTER, MASS.}

\section{ASSFTS, $\$ 186,400$.}

JOHN CUNNINGHAM, Sec'y. JOSIAH O. FRIEND, Prest.

DIRTCTORS.

GEO. R. BRADFORD, HENRY A. BURNHAM, WILLIAM A. PEW, ROPERT FEARS, ANDREW W. DODD, MICHAEL WALEN, JOSIAH O. FRIEND, JOSEPH O. PROCTER, GEORGE J. TARR. JAMES A. STETSON,
MONSON L. WETHERELL, BENNETT GRIFFIN, FRED. G. WONSON, JOSEPH GARLAND. UHARLES S. ROGERS.

D. E. WOODBURY,
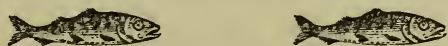

Commission Merechant, $-\mathrm{IN}-$

DRY \& PICKLED FISH,

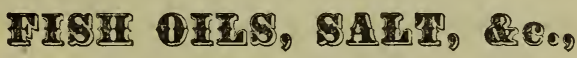

GLOUCESTER, MASS.

ALEx. RTCUTEY, SHIP-SMITH,

And Manufacturer of

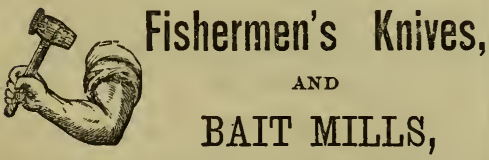

Which we make a specialty. Orders from all parts of the country promptly attended to.

DAST GLOUCESTER, MASA.

\section{THIS BEAUTIFUL PAINTING}

H'as been Photographed, and copies may be obtained of procter rother. It is a fine picture, showing two schooners riding at anchor and another jogging under a dou. ble-reefed foresail. Just such a picture as everybody wants.

Copyright securerl according to law.

$$
\text { Send as cents to }
$$

PROCTER BROS., Gloucester, Mass., and receire by return mail one of the above pictures. 
a belief that it would ever again recorer the ratio of ante-rerolutionary growth. For a period of more than thirty years this fishery ceased to be of any account in the business of the town, but, since about 1860, the increased demand and consequent higher price of fish have induced many of its merchants to send their vessels to the ancient fishing ground which contributed so largely to the early prosperity of Gloncester, and which, in recent years, has been one of the chief sources of that increase in business by which it has risen to its present importance. The success with which this fishery is now pursued is doubtless due in a considerable degree to the practice of trawl-fishing. From the earliest times, till within a few years past, it was the custom of the New England fishermen, who resorted to that Bank, to fish from the ressel only; but they now use the French

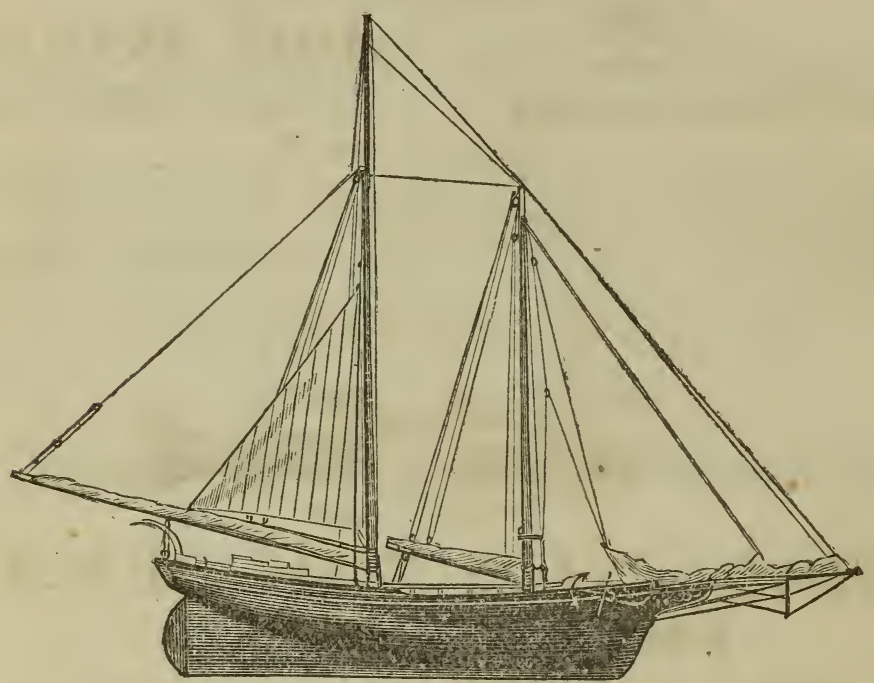

MODEL OF TRAWLER OF 1876.

mode of fisling with trawls, which are lines, sometimes several hundred feet in length, with short lines and baited hooks suspended from them at frequent intervals. They are often set a long distance from the vessel, and as this work must be done and the trawls tended in dories, as their small boats are called, it is sometimes very hazardous, and, unhappily, liable to fatal accidents.

During the first quarter of the present century, when, as we have seen, the Grand Bank fishery was almost totally abandoned by the Gloucester fishermen, the shore fishery continued to give employment 


\section{CUNNINGHAM \& THOMPSON,}

(Successors to POOL \& CUNNINGHAM,)

Producers \&

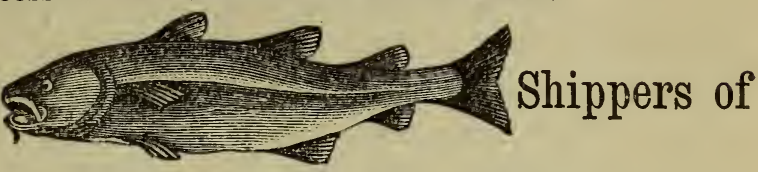

Dry and Dickled Fish,

At the Old Fort Wharf, - - - GLOUCESTER, MASS.

WM. B. CO0MBS,

Fish Buyer \& Shipper

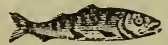

McQUINN'S WHARF,

EAST GLOUCESTER.

iIighest Cash Market Prices Paid.

Extra inducements offered to Nova Scotia vessels coming to the port of Gloncester for a market. All trips settled for as soon as the fish are weighed off.
DENNIS \& COLBY,

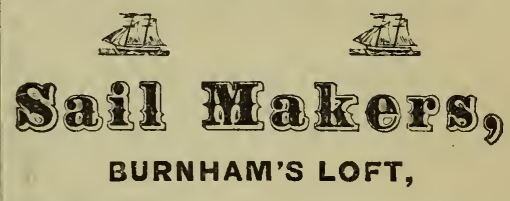

Near Union Hill, Gloucester, Mass.

All orders will receive our personal attention and satisfaction guaranteec.

Repairing promptly attended to.

\section{J. F. WONSON \& CO.,}

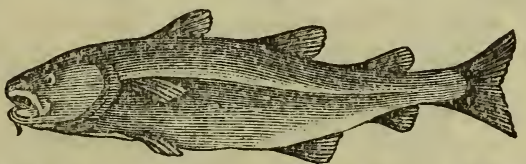

WHOLESALE FISH DEALERS, EAST GLOUCESTER, MASS.

JOHN F. WONSON,

Frederic G. Wonson,
ROGER W. WONSON, Franklin A. WoNSON.

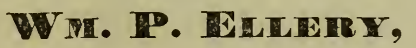 IIOCSE, SHIP \& SIGIPIIIITER, AND DEALER IN \\ Paints, Oils, Varnish, Japan, \\ VERDIGRIS, \\ And COPPER PAINT. \\ Orders for Vessel or House Painting prompt- ly attended to. \\ Opp. Burnham Bros.'
Railway Omice. $\quad$ Gloucester, Mass. \\ F: IMORING d CO, DEALERS IN

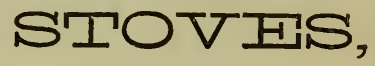 \\ ALSO IN \\ Lanterns, Fog Horns, Tin, Sheet Iron, Copper and Britannia Ware \\ For vessels use. Vessel Work a specialty and attended to with promptness. All or- ders will receive personal attention. \\ 146 Front St., Gloucester, Mass.}


to a considerable number of the people. At the commencement of this period about two hundred Chebacco boats, measuring nearly three thousand tons, and employing about six hundred men, were engaged in it. These boats resorted to the ledges and shoal grounds near the coast, where they found at different seasons, cod, hake and pollock. This boat-fishing was chiefly carried on at Sandy Bay, Annisquam, and the other coves on the outside of the Cape, but the advantage of a good harbor for their large boats drew a few of the people away from these localities, to settle at the Harbor, soon after 1800. An increase in the size of the boats soon took place, and by the end of the period now under consideration sereral pink-stern

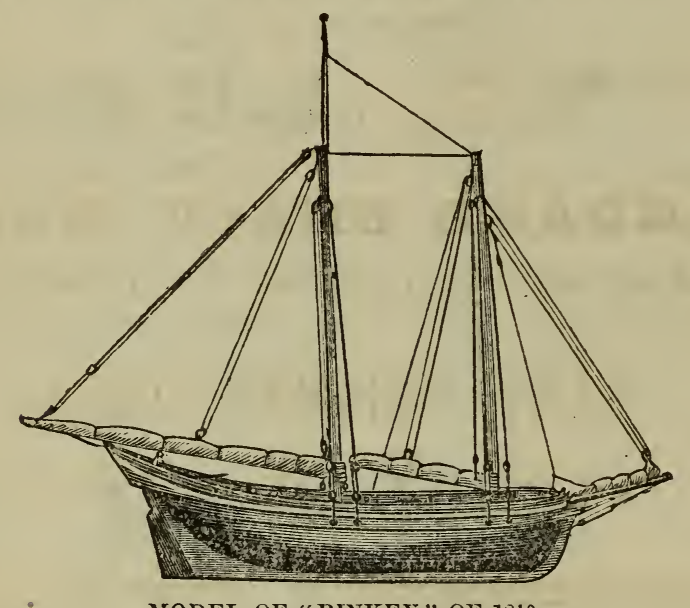

MODEL OF "PINKEY" OF 1810.

schooners, or jiggers, as they were sometimes called, were employed in the business. This shore fishery for cod probably reached its maximum in 1832, when the amount of tonnage engaged in it was 6463 tons, the number of men employed 799 , and the product of fish 63,112 quintals, valued at $\$ 157,780$; to which must be added the bounty of $\$ 25,172$, received from the general government. But another fishery had now for a few years attracted the attention of the fishermen; and the shore-fisling for cod, except that carried on in winter, declined from this time, till it came to be, as at the present day, of insignificant account in the business of the town.

Of the early history of the mackerel fishery in New England, as well as that for cod, very little is known. Gov. Winthrop, standing "to and again" within sight of Cape Ann, all of one day in June, 


\section{T. I. MAYO \& CO.,}

\section{Ship Shandlers de (Srocers,}

DEALERS IN MANILA AND HEMP CORDAGE,

Duck, Chains, Anchors, Paints, Oils, Varnishes, \&c. $\left.\begin{array}{l}\text { T. L. MAYO, } \\ \text { RICHARD A. ATwOOD, }\end{array}\right\}$ NNo. 107 Commercial St., BOSTON.

Agents for TARR \& WONSON'S PATEIT METALLIC OR COPPER PAINT.

FEARING, RODMAN \& SWIFT, SELLING AGENTS OF

Lawrence Duck Company, Old Colony Duck Company, New Bedford Cordage Company,

AND PROPRIETORS OF

\section{STANDARD CHAIN WORIXS,}

23 \& 25 Commercial St., BOSTON.

\section{WEST, PARKMAN \& SON,}

HARDWARE GOODS, $-\Lambda \times D-$

FISLERTEN"S FITHINGS.

JOSEPH WEST,

WILLIAM PARIKMAN, \}

WILLIAM PARKMAN, JR.

No, 5 Dock Square, BOSTON.

Constantly on hand Fish Hooks, Twines and Lines.

\section{EATON, HARRINGTON \& DANA,}

HARDW ARE, CORDAGE

FISHERMEN'S OUTFITS.

\section{N. E. $\Lambda$ GENTS FOR}

Mallory, Wheeler \& Co. Americen Serew Co. Gaylord IIfg. Co. Judd Mifg. Co.

Nos. 25 and 30 PEARL STREET, 
1630, "took many mackerels"; and three years later a man was lost from a passenger ship, by drowning, as he was casting forth a line in trying to catch some. As early as 1653 a coastwise trade in this fish had commenced, and in later years it seems certain that some were shipped to foreign ports; for we find that, in 1692, the remonstrants against an erder passed by the General Court that no person should haul ashore any mackerel with any sort of nets or seines whatsoever, and that no person should eatch any, except for use while fresh, before the first of July annually, in refutation of the assertion that mackerel will not "sare well" in May and June, state that they have shipped mackerel caught in those months beyond sea, and add that they kept as well as those caught in other months. There can scarcely be a doubt, therefore, that this fish was to some extent an article of trade among the early colonists; and we know that, before the Revolutionary war, several vessels were employed in this fishery from the harbors on the south side of Massachusetts Bay; but Gloucester fishermen do not seem to have given much attention to it till about 1821 , for in the thirteen years immediately preceding that date we find that, according to the inspection returns, the whole number packed here was only 1171 barrels. From this time, however, the business rapidly increased; the fish became so abundant in our waters that, in 1825 , a single jigger, carrying eight men, took over 1300 barrels, and in 1831 the whole catch of the town rose to 69,759 barrels; but after the last named date mackerel began to be scarce on our own coast, and the catch declined so rapidly that, in 1840 , it amounted to only 8870 barrels; and in that and the four following years the total aggregate taken by Gloucester fishermen amounted to no more than 66,547 barrels. Abont this time the enterprise of the fishermen led them to pursue the mackerel into their distant retreats in the Gulf of St. Lawrence, and for several years nearly all the ressels of the town engaged in this fishery resorted to that region, and it became the chief source from which the demand for the fish could be supplied. With success widely varying from year to year the mackerel fishery has continued to be pursued to the present time. Late in the Spring months the fishermen start to meet the "schools" when they make their first appearance in the waters south of New England, from which they follow them to our own coast and into the seas of British America; but it is a precarious fishery and it is agreed that a good deal depends upon luck; for there is often a wide difference in the result of the season's work of men equally diligent and equally skilled in the business. Of late it 
GE0. HARVEY,

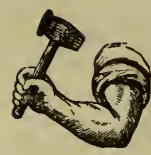

SHIPSMITH,

Duncan St., GLOUCESTER.

Anchors and Vessel Work a specialty. Satisfaction guaranteed.

\section{CAPE ANN Sx INOSW}

Neatly arranged on Cards, in packs of one or more dozens, or in Books, comprising fine varieties.

Price per Doz. \$1.50; Books according to size.

For further particulars write to $\boldsymbol{M} \boldsymbol{r} \boldsymbol{r s .} \boldsymbol{A}$. I. Davis or Mrs. MI. II. Bray, GLOU. CESTER, MASS. AC Oriders aecompanied by cash will receive prompt attention.

\section{Attorney \& Counsellor àt Law, BERGENGREN'S BLOCK,}

\section{Front Street, GLOUCESTER, Mass.}

All business attended to with diligence until finished.

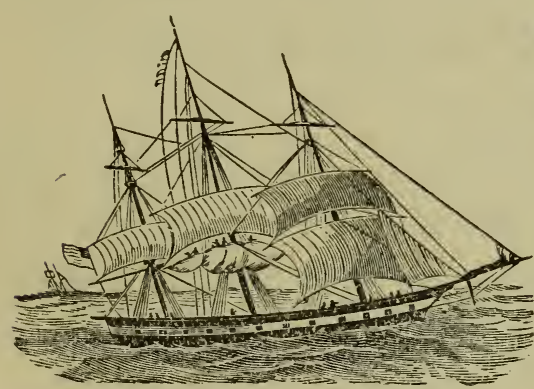

Chresten Nelson, Prop.

Nelson's Pat. Duck Preserver,

(PATENTED JAN. 7, 1873.)

Warranted to protect Ships, Sails, Aunings, Tents, and all kinds of Iremp and Cotton Canvas from Mildew and Decay.

SAILS, \&c., saturated in this PRESERVER, will keep free from mildew and mould till worn out, and remain white as when new, as shown by numerous Testi. monials, after a test of two years. MANUFACTURED AT

No, 81 Spring St., Gloucester, Mass. SEND FOR CIRCULAR.

\section{W. W. FRENCH,}

Attorney\& Counsellor atlaw,

TAPPAN BLOCK,

128 FiroNT STREET, GLOUCESTER, MASS.

\section{MOSES L. ANDREWS,}

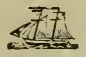

$\stackrel{10}{2}$

कîn

NEAR CENTRAL WHARF,

Rogers St., Gloucester, Mass. 
has become customary to take these fish by seining, and when the net surrounds a "school," there is a chance, indeed almost a certainty, of a great haul; but it sometimes happens to a fishing crew that no such chance occurs for months, and a bad rojage for the vessel and the men is the unfortunate result. The cases of total or partial failure, however, are not sufficiently numerous to create discouragement, or to excite apprehension that Gloucester will soon cease to exhibit that preponderance in this fishery it has so long enjoyed. It is true that the last year was one of poor success, but in the preceding the quantity of mackerel packed in this city was 118,314 barrels, of the net value probably of more than one million dollars.

A remarkable feature in the modern business of Gloucester is the fishery for lialibut on Georges Bank and Grand Bank. This fish is. the only one of the flat kind, so far as we know, that is extensirely used as an article of food in this country. It is found in the waters of Northern Europe, and is said to afford a considerable part of the diet of the people on the coast of Lapland, where it sometimes attains the weight of five hundred pounds. Those of a little more than half this weight, or about three hundred pounds, are considered large specimens by our fishermen. This fish is most highly esteemed when in a fresh condition, and we are not aware that it goes at all into the market in a pickled state, thongh great numbers are "fletched," to use a fisherman's phrase; that is, the skin with a portion of the flesh attached, is cut into strips, salted, and smoked, and in this condition, when slightly broiled, finds much faror as a tea table relish. There are large establishments in Gloucester for curing halibut in this manner, and there is always a demand for all they can supply. The fins of the fish are also preserved in salt and pickle; but those who eat them in this condition know but little of the richness and delicacy of the fiesh fin.

It does not appear that the halibut has ever been abundant near the coast, though the shore fishermen of former times occasionally found them when fishing for cod, and were able to furnish a limited supply for home consumption. ,It was not till the discovery of the great feeding ground of this fish, on Georges Bank, that the attention of our fishermen was directed to a special prosecution of this fishery ; and, incleed, not till the opening of railroad communication with all the cities and principal towns in the country, and the use of ice rendered it possible to supply very distant inhabitants with this excellent article of food in a fresh condition and at a low price, did any considerable number of ressels engage in the business. The Boston 


\section{F. AUSTIN \& CO. Fishermen's Bread and Crackers.}

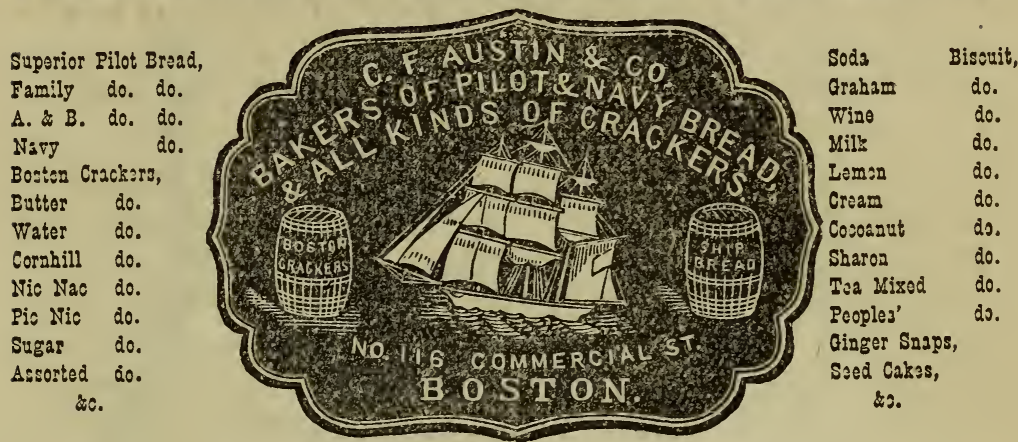

The above articles kept constantly on hand for sale, made from carefully selected Flour, and baked in the most thorough manner; put up in suitable packages for Grocers, Hotels, and Families.

$S H T P B R E A D$ and $C R A C K E R S$ neatly packed in Barrels, Half-Barrels, Boxes and Tins, and delivered at short notice and warranted to keep on long voyages.

NO. 116 COMMERCIAL STREET, BOSTON.

\section{WHITON, BROTHER \& COMPANY,}

AGENTS

HINGHAM CORDAGE COMP'Y,

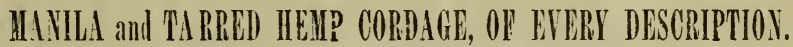

\section{WOODEERRY MALS COTTON DUCK,}

ALL WIDTIIS AND NUIBERS.

UNITED STATES BUNTING COMPANY, BLNTING ALL COLORS AID IIIDTIIS.

IMPORTERS, AND DEALERS IN

Russia, Manila and American Hemp, Oakum, Wire Rope, ANCHORS, CHAINS, RUSSIA BOLT ROPE, \&C. 31 and 33 Commercial Street, - BOSTON. 
market, in which, hitherto, one or two thousand pounds of halibut would have sufficed for a daily supply, now furnished purchasers for all that could be brought, till the weather became too warm for distant transportation; and, when that season arrived, the fishermen could sell at home, to be smoked and dried, all that could find no sale in the former place. It was about 1836 that a vigorous prosecution of this business commenced, and it had risen to such importance in 1847, that the Gloucester vessels took in that year considerably more than three millions of pounds, which sold for something over seventy thousand dollars. Besides the Georges fishery for halibut, it has been customary, for a few years past, for the fishermen to resort to the Grand Bank, for the sole purpose of trawling for this fish, and in some instances more than a hundred thousand pounds have been brought home as the result of a few weeks' trip.

On the opening of railroad communication betreen Boston and Gloucester, it seemed expedient and practicable to bring the Boston and other dealers in halibut to Gloucester to purchase ; and, to carry out this design, a company was formed to buy the fish of the fishermen, and await purchasers from abroad. But the enterprise, in a money point of view, was a failure. The price to be paid was stip. ulated for different periods in advance, and it so happened that it was a year (1848) when Georges Bank yielded as it never had before. The object, however, at which the company aimed, was fully accomplished, which object was to make our own town the chief market for this fish, so that now, however large the supply, local dealers are ready to take them on arrival, and furnish Boston and other customers according to the demand.

Besides the fishery for halibut, Georges Bank has also contributed in another way and to a much greater extent, to the recent prosperity of Gloucester. The great abundance in which cod is sometimes found there recalls to mind the "pestering" of Gosnold's ship with them off Cape Cod, and the "strange fish-pond," where Capt. Smith found them so plenty, near Monhegan. This abundance, and the introduction of fresh herring from Newfoundland to be used for bait, induced our fishermen to engage actively in a winter fishery on that Bank. The success of the trip depends mainly upon wind and weather. Sometimes the whole fleet return to port with the loss of cables and anchors and with other damage, and without fish to compensate. Often better luck attends them, and occasionally a few favorable trips in succession yield a generous but still hardly adequate reward for the risk, labor and suffering of the employment. 


\section{To Wholesale Dealers in Fishing Tackle,}

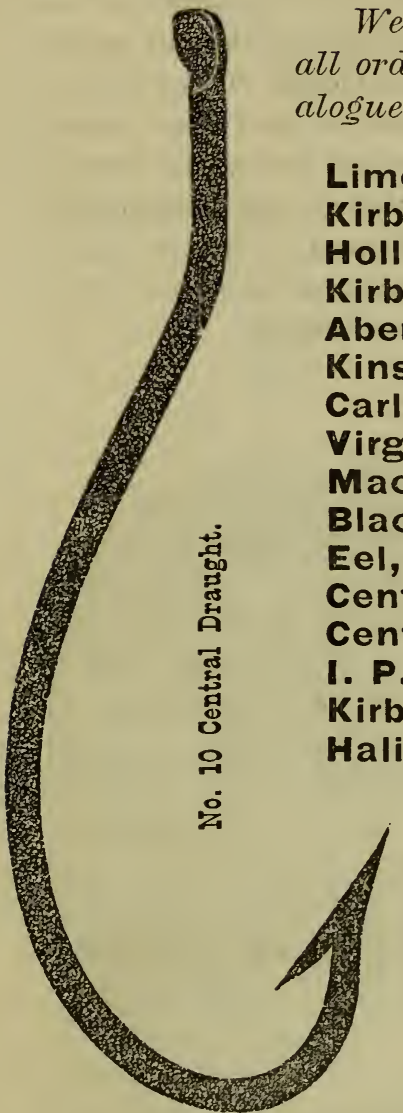

We are now prepared to promptly fill all orders for Hoolss embraced in our Catlogue, consisting of a full line of

Limerick, Ringed and Flat. Kirby, Hollow Points, Ringed and Flat. Kirby Bass and Salmon, Flat. Aberdeen, Flat. Kinsey, Ringed and Flat. Carlisle,

Virginia, Flat.

Mackerel, Flat. Blackfish, Eel, Ringed.

Central Draught, Eyed and Flat. Central Draught, Ringed.

I. P. Cod, Ringed and Flat.

Kirby Sea, Ringed and Flat. Halibut, Ringed.

count ONE HUNDRED HOOKS in each BOX, pucked in fine order.

Parties ordering our goods can depend upon having their orders promptly filled and at prices below any other matser's, or any importer in the country.

SEND FOR CATALOGUE AND PRICE LIST.

\section{American Needle \& Fish Hook Co.,}

NEW HAVEN, CONN. 
In another place, in these pages, interesting particulars in relation to this fishery may be found, and among the statistics of the business the mind will dwell with painful emotions upon the list of those who have found in it a watery grave, and also an unknown end; for no tidings ever come from the missing Georges fisherman. An unusual 'absence gives rise to fearful apprehensions, and anxious friends at home watch from the hills in agonizing suspense for the returning sail ; but nothing comes save the moan of the sea which sounds their requiem. None but the stoutest hearts will brave the perils and hardships of such an employment, or of the dangerous trawl-fishing on Grand Bank; and the mournful losses, with all their sad consequences, constitute a serious drawback upon the otherwise happy prosperity of the fisheries of Gloucester.

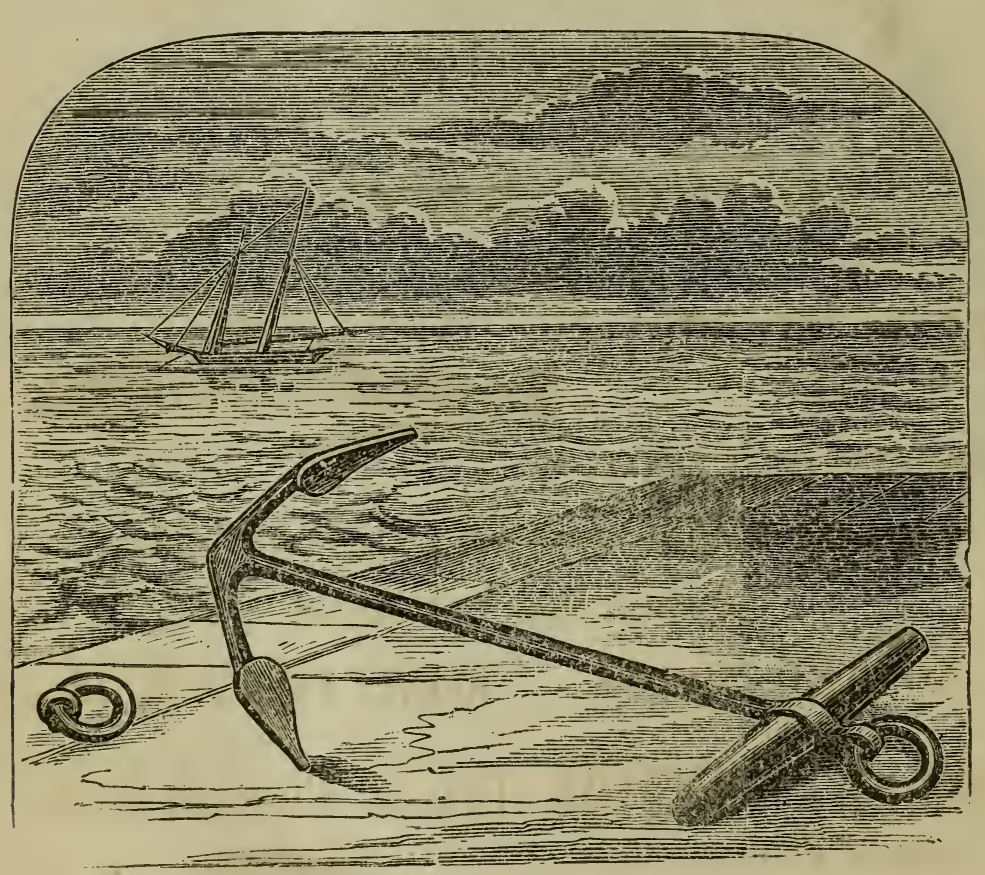




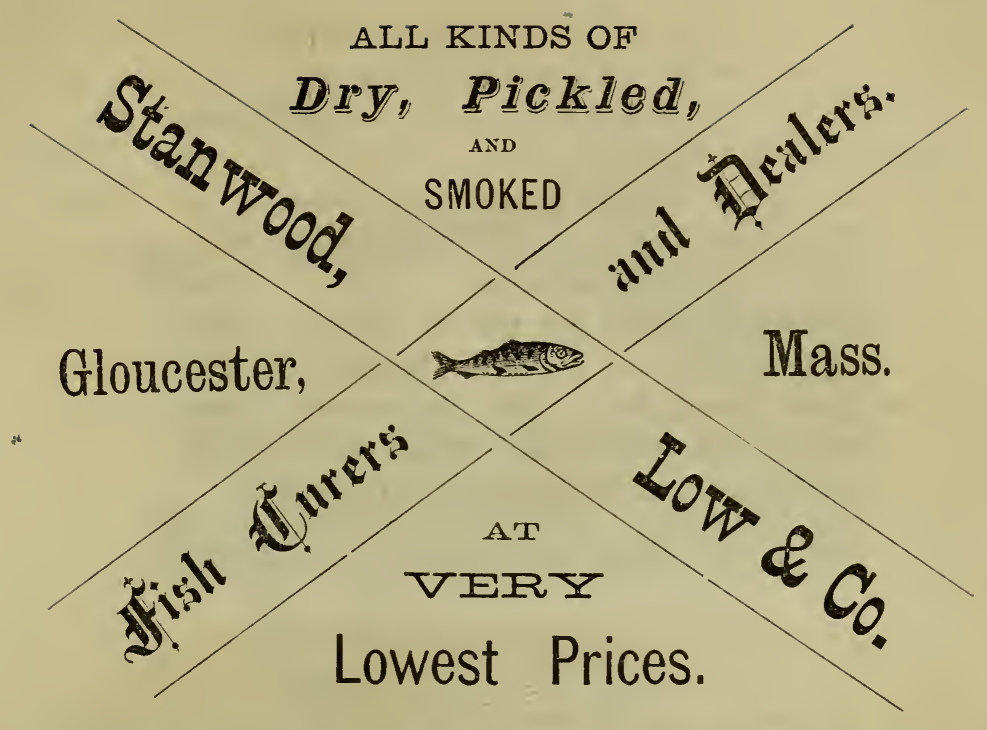

\section{ANDREWS, RICHI \& CO.,}

WHOLFSALE:

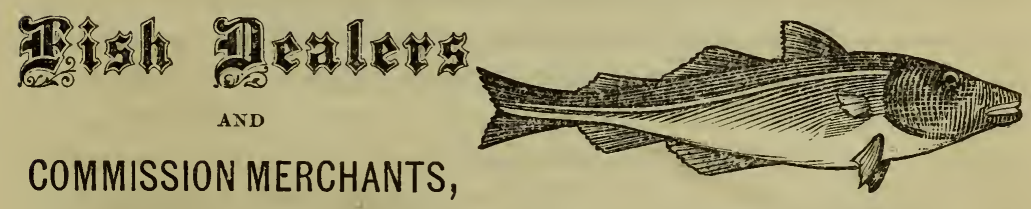

I \& 11 Commercial Wharf, North Side, BOSTON, MASS.

\section{LEONARD WALEN,} DEALER IN

\section{PRESII, DRI \& PICLLED FISI,}

Curriers' \& Coi Liver Oil. grocerilis, OUTPITTIIG GoOzs, lic.

Constantly on hand.

Rocky Neck, - Wast Gloucester. P. $O$. address, Gloucester, Mass.

\section{HARVEY KKOWLTON, JR,,}

Wholesale Dealer in

Dry \& Pickled Fish,

\section{सareses}

\section{SMOKED HALIBUT,}

Fish 0ils \& Vessels' Outfits,

Rocky Neck, - East Gloucester.

P. O. address, Gloucester, Mass. 


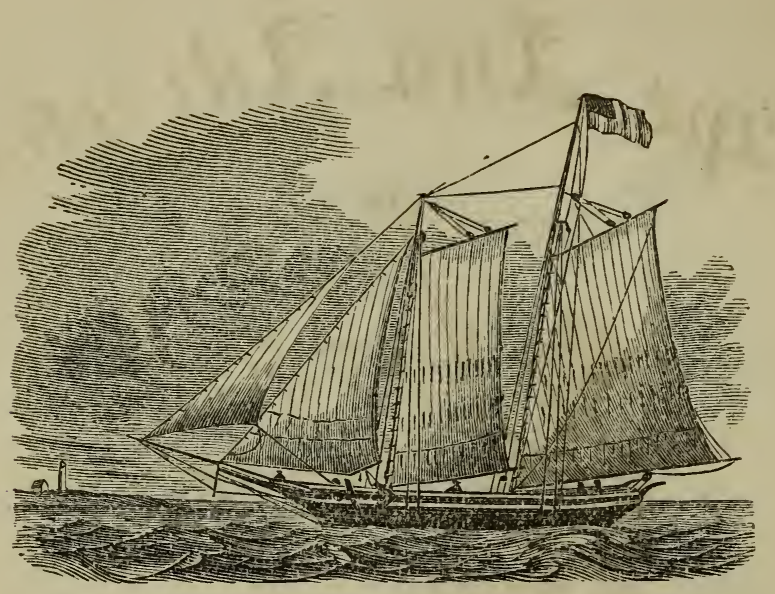

\section{CHAPTER 4.}

Changes in the Fismeries-Seekixg New Fishing Grodnds-

\section{The Fisheries as at Present Conducted.}

The fishing industry of Gloucester is almost constantly undergoing changes in its character and methods. Within the last thirtyfive years an almost entire revolution has been wrought in the business. In 1841 the fisheries, after a gradual decline for many years, had about reached their lowest ebb, and from that point the tendency was in the direction of expansion. Since 1847, notwithstanding the decadence of the foreign commerce of the port, which at that time employed one ship and nine brigs, the tonnage of the District has increased from 357 vessels, of a total of 17,548 tons, to 503 vessels, of a tonnage of 30,724 tons ; and the improved character of the ressels engaged in the fisheries is shown in the fact that notwithstanding the disappearance of the square-riggers from the district, the average tnmnage of the fleet has increased from 49 to 61 tons. An average Gloucester fishing schooner is now fully equal, in every detail of equipment and the qualities which give speed and safety, to the first-class yachts that dance upon the waters of Massachusetts Bay or Long Island Sound; while her outfits for the prosecution of the business contain every convenience which modern ingenuity can devise, and her crew are supplied with all the necessities of life and regaled on many of the luxuries unknown in ordinary passenger transportation by sea. 


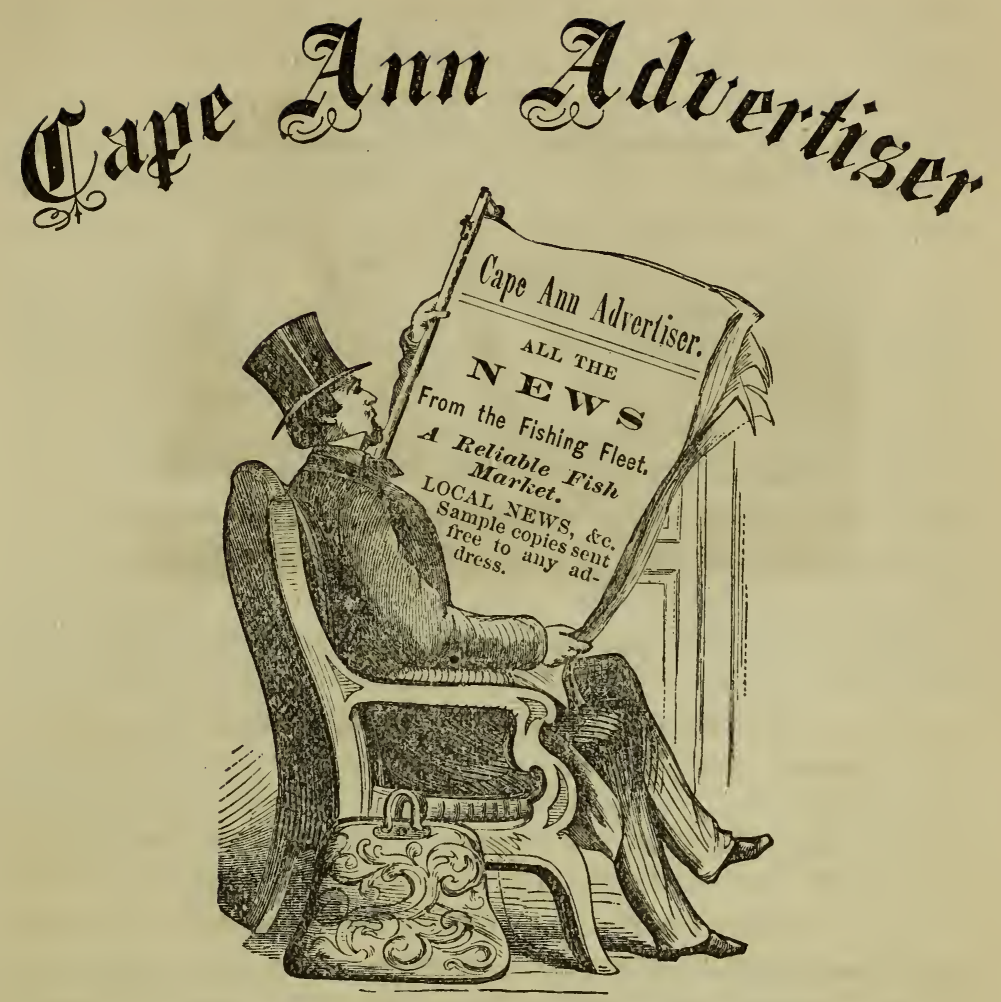

$\Lambda$ handsomely printed sheet of THIR'TY-TWO COLUMNS, issued every Friday Morning, by

\section{PROCTER BROTHERS,}

\section{EDITORS AND PROPRIETORS,}

\section{Gloucester, - - - - Mass.}

Each issue has all the Local News of Cape $A n n$, together with all the Fishing Items, a reliable Fish Market, Good Story, and choice Miscellaneous Reading Matter, making it emphatically

\section{THिस्ष

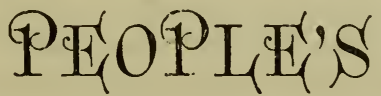 \\ PAPFE⿱R⿴囗十⿱⿴囗十丌.}

The Best Advertising Medium on the Cape.

CIRCULATION, 3,500 COPIES. TERMs, \$2.65 per year, which includes postage, strictly in advance. Sent to any part of the country on receipt of price.

Subscribe for it if you wish to peruse a Live Local Newspaper. 
The great change effected in the character and methods of the Gloucester fisheries, within a comparatively few years, has been the result of numerous causes. In the early days of the town there was little difficulty in securing good fares of merchantable fish, in pleas. ant weather, at a short distance from shore, and accordingly the shore fishery, with its inexpensive craft and outfits, assumed leading proportions. As the fish removed farther and farther from the shore, in consequence of the disappearance of fish food in near proximity to the coast, a better class of ressels and longer royages became a necessity. With this improrement in fishing craft, and increased expense, new fishing grounds, and a longer fishing season, became possible and necessary. 'The enterprise of Gloucester fishermen was not long in finding new resorts for their calling, and the introduction of the herring trade, by supplying bait at proper seasons, gave an added impetus to the business. The increased facilities for transportation, and the development of the ice business, affording better means of preserving and forwarding fish long distances, however, wrought the greatest rerolution that these fisheries have witnessed, and placed Gloucester in the forefront of the fishing ports of America. Since the opening of railroad communication with Gloucester in 1846 , but more particularly during the past dozen years, an immense business has been done in shipping fresh fish to all parts of the country, the orders being received daily by telegraph, and the fish being iced and shipped direct to distant customers. Another outgrowth of the increased facilities for transportation is the direct shipment of cured fish to all parts of the country, a business that has increased from a modest beginning in 1863 to huge dimensions, until Gloucester has become the distributing headquarters for its own productions, and to a considerable extent for those of other fishing ports. Several business houses in this line send out trade circulars weekly, and fill large orders daily from a long list of correspondents. A single house in 1874 shipped nearly 50,000 quintals of codfish, 214 tons of codfish stripped from the bones and skin and packed in small compass, and orer 100 tons of smolied halibut, to its numerous customers in the West and South. It is largely through the importance of this branch of the business, in connection with the fresh fish trade, that the Gloucester Branch Railroad has proved a profitable property to a bankiupt corporation, and that a large steamer, making daily trips to Boston, and a respectable fleet of first-class freighting ressels, plying between Gloucester and New York, find lucrative employment. 


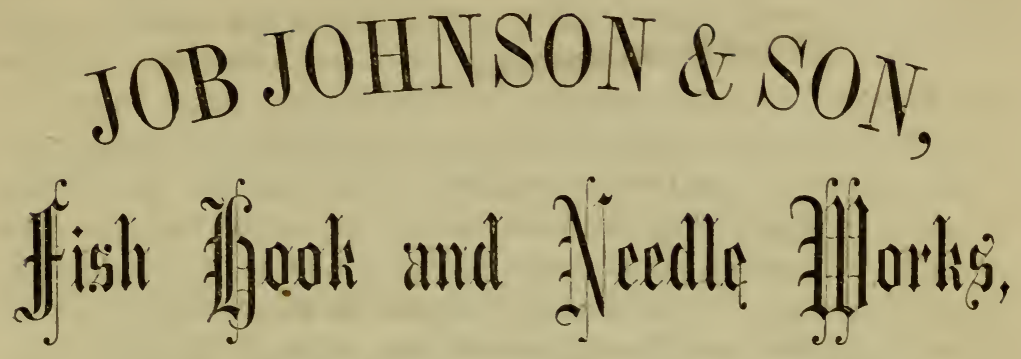

COR. MYRTLE \& BEDFORD AVES.,

\section{BROOKLIN, N. Y.}

Manufacturers of Best Cast Steel Wire,

\section{And GENERAL HARDWARE,}

Patent, and all other descriptions of Fish Hooks, Needles, \&c.

Sail Needles, Pack and Bag Needles, Upholsterers' Needles,

Mattress Needles, Surgeons Needles, Sparing Needles,

Dissecting Needles.

Every Description and Size of TORTIONAL DOOR SPRINGS.

PATENT AUTOMATIC GATE HARDWARE.

JOB JOHNSON'S

\section{SPHERICAL PATENT UNIVERSAL BALL CASTOR}

FOR FURNITURE.

PATENT AUTOMATIC BURGLAR PROOF BLIND and SHUTTER FASTENER; PATENT UNIVERSAL

CLOTHES LINE HOLDER.

All Descriptions of Steel Wire Goods, Machinery, Springs, \&c. \&c.

N. B.-Particular attention paid to Tempering and Finishing all kinds of Steel Wire Goods.

Sole Agents for the Celebrated Shrimpton \& Sons Superior Sail and other Necdles. 
With these advantages, it is not a matter of surprise that the fisheries of Gloucester should cover a wide range of operations, and that a large proportion of its fleet should be engaged in some branch of this pursuit during every month of the year, a fact that does not hold true of any other New England fishing port. With a business capable of indefinite expansion ; with a fleet unsurpassed in seagoing qualities; with a maritime force of hardy men cradled on the deep from early youth; it would be singular if Gloucester failed to turn its attention in whatever direction fishing enterprise held out a prospect of successful operations. The successors of the men who braved the perils of the sea in the primitive craft of the earlier years of the eighteenth century; who were undaunted from pursuing their avocation by sarage or hostile forces ere the Republic was born; are not the men to shrink at any hazard by storm or ice, and neglect opportunities that promise a successful issue in their dangerous calling. It is not a matter of surprise, therefore, that in the Spring of 1860 , after an annual decrease for three years in the mackerel catch of the port, until the product had been reduced nearly twothirds in quantity, the project should be seriously contemplated of embarking in the mackerel fishery of the North Sea, on the Norwegian and Swedish coasts, where the prospects of successful fishing were beliered to be favorable. Happily, howerer, that year saw a revival of this industry, the mackerel catch of 1860 being much larger than ever before, and the project was abandoned. Ten years later, when the halibut fishery had assumed considerable proportions, attention began to be turned to new grounds for this fishery, and in 1870 an experimental trip was made to the coast of Greenland, with results which gave promise of a successful pursuit of this distant fishery. During the next two years half a dozen ressels made halibut trips to Greenland, but in 1873 the fleet was reduced to four vessels, whose royages did not prove remunerative, and the distance of the fishing grounds, the uncertainty attending the business, the high cost of its prosecution and the dangers from storms and icebergs led to its abandonment. The pioneer in this fishery, however, Capt. John S. McQuinn, was still possessed with the purpose of finding new fishing grounds, and on the 23d of May, 1873, with a crew numbering twenty men, he set sail in the staunch schooner Membrino Chief, for the fishing grounds on the Icelandic coast, where the fishermen of France and Northern Furope have long pursued profitable rentures. It is probable that the royage was made at an untoward season, since it proved a failure, the res- 
ADDISON WITHAM,

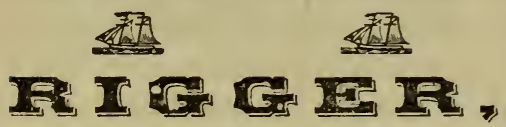

Loft at Burnham Bro.'s Railway,

Water St., GLOUCESTER, Mass.

Orders promptly attended to; Satisfaction guaranteed.
WM. COOS, JR.,

\section{Plets and Seines,}

Tarred and Repaired.

NETS, SEINES, TIVINE and FISHING NETTINGS, of every description, furnished to order. ALL Work GUARAxteEd.

\section{SPIRTU ATREET,}

Near the Cape Ann Anchor Works,

GIOUCESTER, MASS.

Second-TIand Tigging Furnished.

H. H. BENNETT, Treasurer.

SCOTT WEBBER, Supt.

\section{Cape Ann Granite Co.}

\section{- FURNISH -}

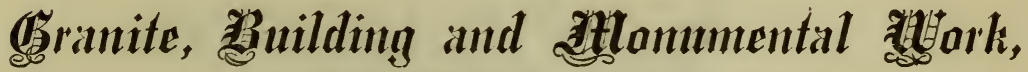
OF EVERY DESCRIPTION; ALSO DEALERS IN

GRANITE FLAGGING \& PAVING BLOCKS, Office, Simmons Building, 40 Water St., (Room 12,)

Quarries: Bay View, Gloucester, Mass. BOSTON.
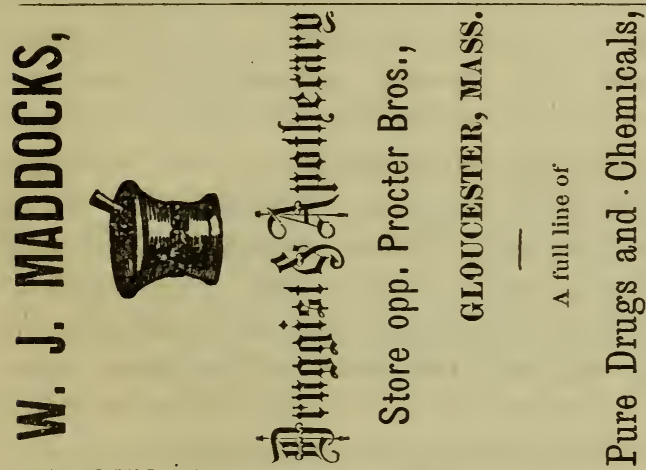

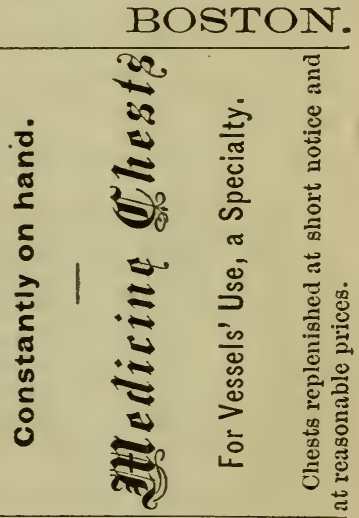

BUCK'S BOOTS.

\section{JONATHAN BUCK,} Manufacturer of

\section{Fishermen's Boots}

OF VARIOUS QUALITIES,

Hand.made and warranted superior to any other manufacture.

Factory at Harwich,

CAPE COD, - _ MASS.

\section{ADOLPH VOSS,}

Owner and Manufacturer of

Voss' Improved Bait Mill, Richardson's Imp. Bait Mill, Small's Patent Boom Crotch Supporters,

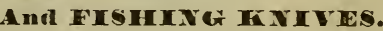

All kinds of FIsHING $\Lambda$ xchORs constantly on hand. Vessel Work and Jobbing of every description promptly attended to. Galvanizing done in all its branches.

Shop foot of Duncan St., near Rail. ways, GLOUCESTER, Mass. 
sel being obliged to return empty, and the experiment has not been repeated.

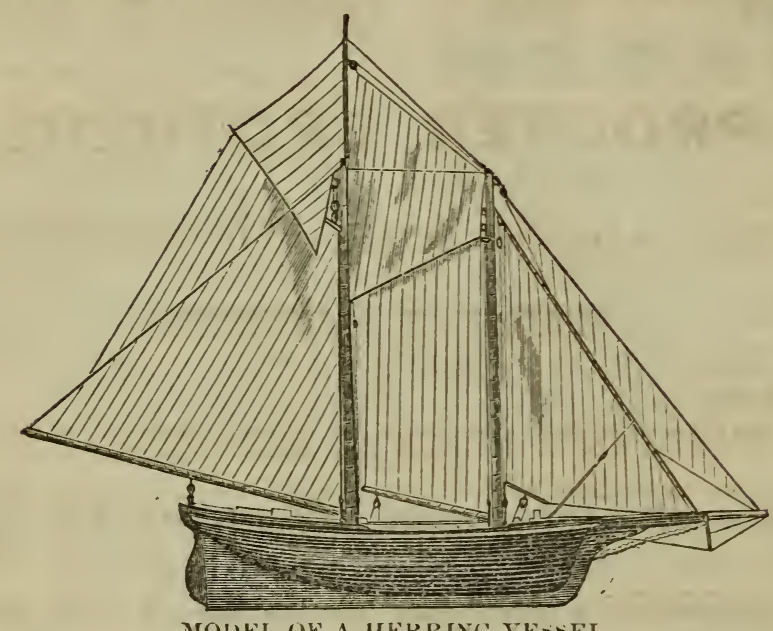

MODEL OF A HERRIYG VESSEL.

The Newfoundland and New Brunswick Herring Fisheries, of comparatively recent origin, while not unattended with hardship and danger, became at once an important anxiliary of the Georges and Banks fisheries, and have been pursued nimemittingly from the start. During the present season herring hare been shipped hence to Sweden, at a good profit, and it is not impossible that this may prove the initial step toward the resumption of exportation of fish to foreign ports, an important industry of the port in the early days of its fishing enterprise. The Spring of 1876 has also been marked by a new feature in the Georges fishery, the capture of halibut in immense quantities in deep water on the edge of the bank, good fares having been secured in a hundred and fifty fathoms of water, a greater depth than was before thought likely to furnish profitable returns.

As at present conducted the fisheries of Gloncester furnish remunerative employment for its ressels and mariners for the greater part of the year, and it is not probable that any considerable portion of its energies need be turned to new fishing fields in the years to come.

With the close of one fishing season another is inaugurated. On the winding up of the nackerel fishery, and the partial suspension of the Bank fisheries in the Fall, the better class of ressels thus employed commence fitting for the Herring Trade, to which the ener- 


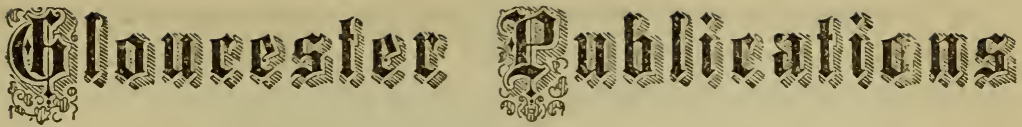 BY}

\section{PROCTER BROTHERS, \\ Publishers and Booksellers. \\ HISTORY OF GLOUCESTER;}

BY HOx. JOHX J. BABSOX. A IIandsome Cloth Bound, \& mo. volume of 610 pages. Price \$5.00.

\section{FISHERMEN'S MEMORIAI AND RECORD BOOK;}

A complete History of the Gloucester Fisheries, from 1830 to $18 \% 3$, giving a record of the vessels and men lost for nearly half a century, thrilling incidents accompanying the perilous calling of the fishermen, interesting sketches of life on board a fishing craft, together with maratime poetry. Handsomely iliustrated. Cloth \$1.50; Hape \$1.40.

\section{FISHERMEN'S BALLADS and. SONGS OF THE SEA;}

A fine collection of songs, many of them written by these hardy toilers of the sea. Paper covers, handsomely illustrated. Hrice jo cents.

GLOUCESTER AND ROCRPORT DIRECTORY;

RPrice \$1.50. Copies of the above sent to any adress, post pair, on receipt of price.

DESAGAR 178 CONGRESS ST.

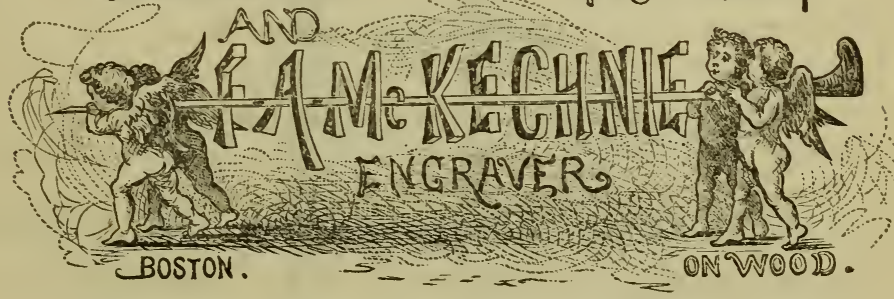

Particular attention paid to the engraving of

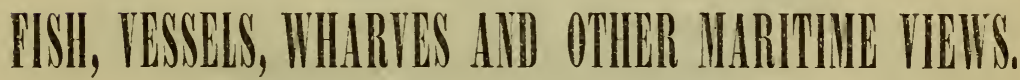

Many of the Cuts in this Book were furnished by

\section{F. A. MCKECHNIE,}

178 CONGRESS STREET, - - BOSTON.

ALL ORDERS PROMPTLY ATTENDED TO. 
gies of quite a fleet are devoted during the winter months. A few ressels only engage in what is known as the salt herring trade, the majority of the fleet securing their fares fresh, freezing them thoroughly and stowing them in bulk, allowing their cargoes to remain undisturbed until they are marketed in as good order as when taken from the water. The Newfoundland herring trade was inaugurated in the winter of 1856 , and has been pursued with varying success since that time. This fleet usually sails from the middle to the last of November, with an outward cargo of such supplies as are likely to find a quick demand among the herring fishers of Newfoundland, which are exchanged for the products of the sea. The crews of the fleet do not engage in fishing to any extent, being occupied in taking proper care of the herring purchased of the local fishermen. Having secured a cargo they return home, usually arriving in January and February, when a portion of their cargoes find a ready sale to the Bank fleet, for bait, the rest being marketed in Boston, New York and Philadelphia markets, for food, where they are in active demand, especially during Lent. The business is an important one, furnishing employment for the vessels and men at a time when they might otherwise be compelled to lie idle, and providing the means for the early embarkation of the Georges and Bank fleets in the late

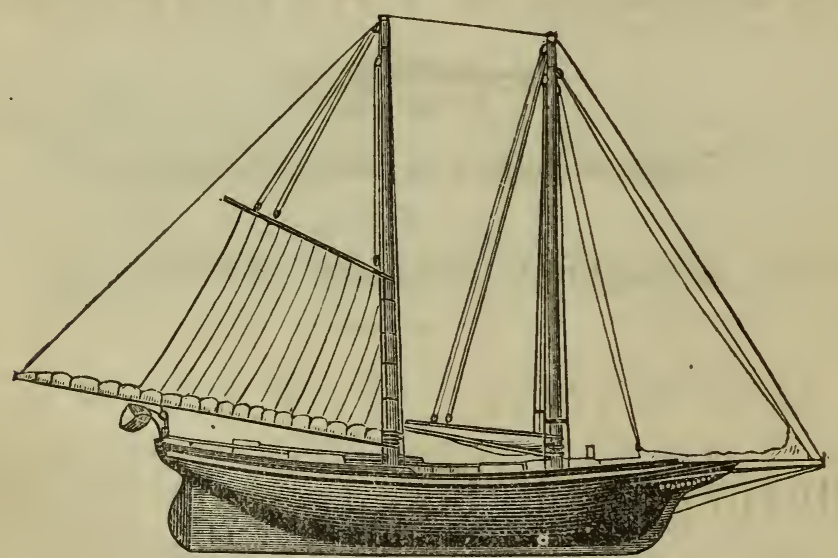

MODEL OF A GEORGESMAN, $18 \% 6$.

Winter and early Spring months. The business is also a godsend to the people of Newfoundland, who are thus enabled to exchange the products of their Winter fishery for the necessaries of life on inuch more farorable terms than would otherwise be possible. The 


\section{CALVIN S. CROWELL \& CO.,}

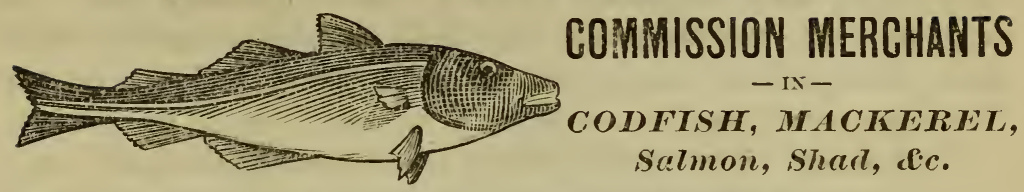

No, 124 North Wharves, PHILADELPHIA, Pa,

Referexces :-W. H. C. Fisher, New York, Messrs. Wise \& Russcll, Boston, B. A. Baker, Gloucester, Messrs. Geo. Trefethern \& Co., Portland, Me.

\section{G. \& J. T. DONNELL,}

MANUFACTURERS ON

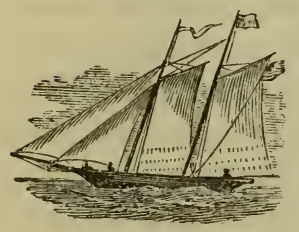

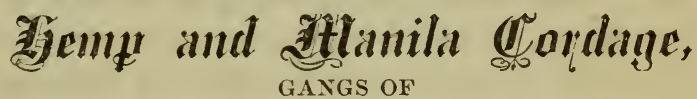
STANDING \& RUNNING RIGGING, Fishermen's Cables.

BOLT'ROPE, LATHYARY and ITIRE ROPE furnished at Short Vutice.

- BATIT, MATNE.

\section{CROWELL PATTANCALL,}

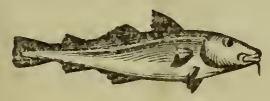

Commission Merohants - IN -

CODFISH, MACKEREL, SALMON, HERRING, OILS, \&c., A. LEAvitT CrowELL, ONATANGALL. 39 Water Street, NEW YORK. MUNROE STEVINS,

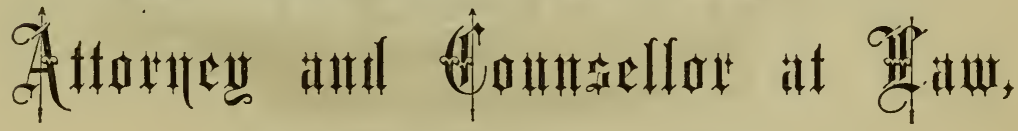
SAWYER BLOCK,

Front Street, - Gloucester, Mass.

Having trustworthy associates practising in the courts in and near Boston can satis. factorily attend to all cases pending therein entrusted to his care. 
New Brunswick herring fishery is another valuable pursuit, and attended with much less danger than the more distant voyages to Newfoundland. In the season of 1874-5, twenty-three schooners made Newfoundland trips, and thirty-three were engaged in the New Brunswick fishery.

Early in February, on the arrival of their supply of bait, the Georges fleet fit away for their early trips, and the Grand and Western Bank fishery assumes more important proportions. The cost of an average Georgesman fitted for sea is about $\$ 7,868$; this includes the cost of hull, $\$ 5,200$, spar's, $\$ 100$, rigging, $\$ 550$, sails, $\$ 575,230$ fathoms of cable, $\$ 450,3$ anchors weighing $500 \mathrm{lbs}$. eash, $\$ 120,12,000$ herring for bait, $\$ 150$, dory, 30 tons of ballast, platforms, ice-houses, gurry-pens, lines, cabin furniture, lanterns, horns, compasses, 4 tons of ice, wood, coal, water, etc. Each ressel takes a crew of eight or ten men, and ordinarily is absent from two to three weeks on a trip. The fish are caught by hand lines, and each man keeps account of his catch by cutting out the tongues of the codfish, which are carried to the skipper for record when the day's work is closed, and by marking the halibuto caught, on the head or tail. At the end of the voyage each man's halibut are identified and weighed separately, and the average weight or ralue of the codfish taken is ascertained, and each man credited with the number caught. The gross proceeds of the catch are subject to deductions for the cost of bait and ice, and one-fourth of one per cent. is reserved for the Widows' and Orphans' Fund, so that each man engaged in the business contributes something towards the support of the families of those whose lives are sacrificed in this hazardous occupation. The net stock, or the amount remaining after the above deductions have been made, is divided equally, one-half to the crew, to be distributed according to their individual catch, subject however to a deduction of each man's share of the "crew's expenses," consisting of cook's wages, water, medicine chest and milk, which expenses are borne equally by the crew; the other half of the net stock goes to the vessel. The business is at its height in the perilous months of February and March, and the hardy men who follow it are called upon to wrestle for their lives with many a cruel storm.

No class of ressels are better calculated for a battle with the storm-king, and no braver sonls tread the deck, but the contest is an unequal one, and many a staunch craft and gallant crew go down in the conflict. In a single storm, on the night of Feb. 24, 1862, fifteen Gloucester ressels and one hundred and twenty men were lost, 
D. A. STORY,

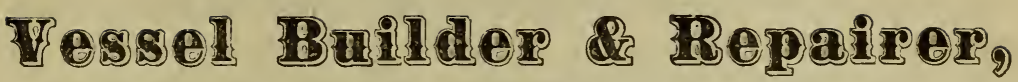

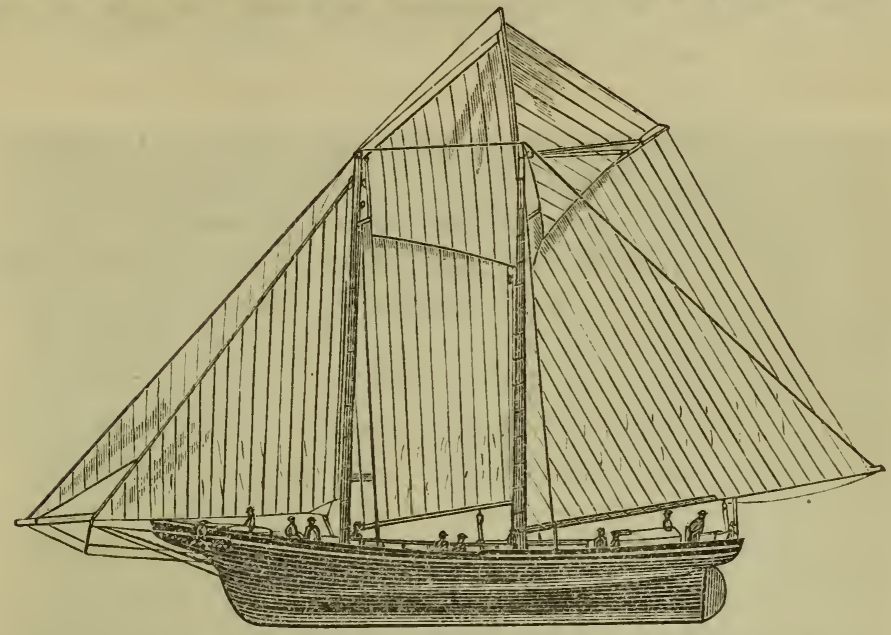

Shipyard on Pearce St,, GLOUCESTER, Mass. Kelham, Fitr \& Co., M.ANUFACTURERS AND DEALERS IN

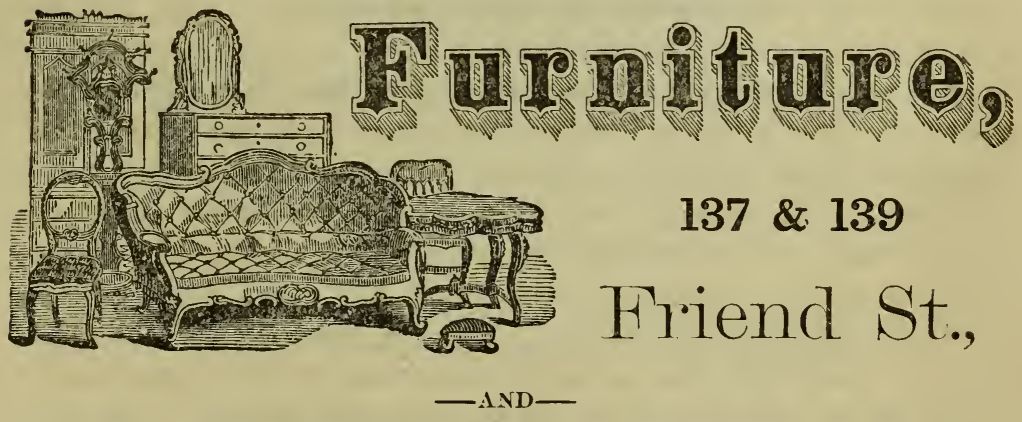

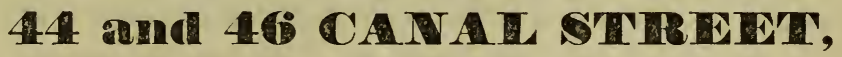
CORNER OF MARKET STREET, 
leaving seventy widows and one hundred and forty fatherless children to mourn for the loved ones who would return no more. Last year two hundred vessels were engaged in the Georges fishery at some time during the year; a large fleet followed the business the greater part of the year, and a total of 1348 fares were landed at Gloucester.

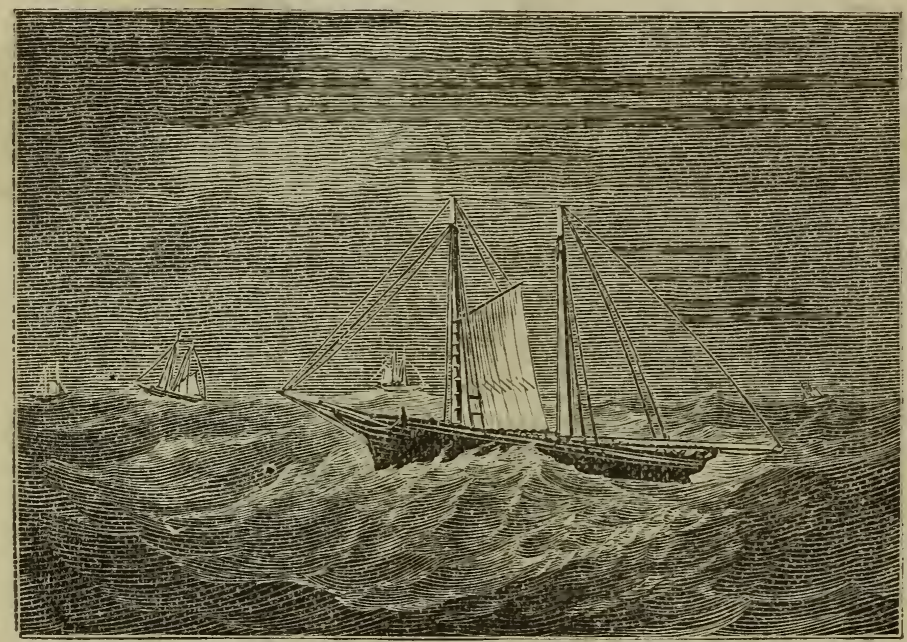

ON GEURGES IN A STORM.

The Grand and Western Bank Fishery is pursued to a greater or less extent during every month in the year. Last year this business employed 175 vessels, and 499 fares. were landed. The business may be classed in two departments, a portion of the fleet making short trips and bringing in their fares fresh, to supply the fresh fish trade, and the rest of the fleet making longer trips and dressing and curing their fish as they are caught. This business employs the best class of fishing vessels known to the waters of the coast. A modern "banker," of average tonnage, costs about $\$ 8,800$. Such a vessel, manned by a crew of twelve men and making nine trips to the Bauks, being at sea 302 days, will require an expense of $\$ 1023$ for trawl gear, $\$ 1824$ for vessel's expense, $\$ 1426$ for provisioning.

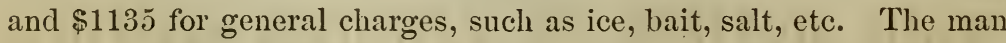
who ventures on a trip in a "trawler" finds little of the "pleasing content" described by the early voyager. For him at least there is little of romance in "the apostles' own calling." Life on the banks he finds a constant round of drudgery, so long as he is able to make his daily rounds. He must rise carly and work late in order to visit 


\section{DAVID M. HILTON,}

\section{Teaming \& Boarding Stable.}
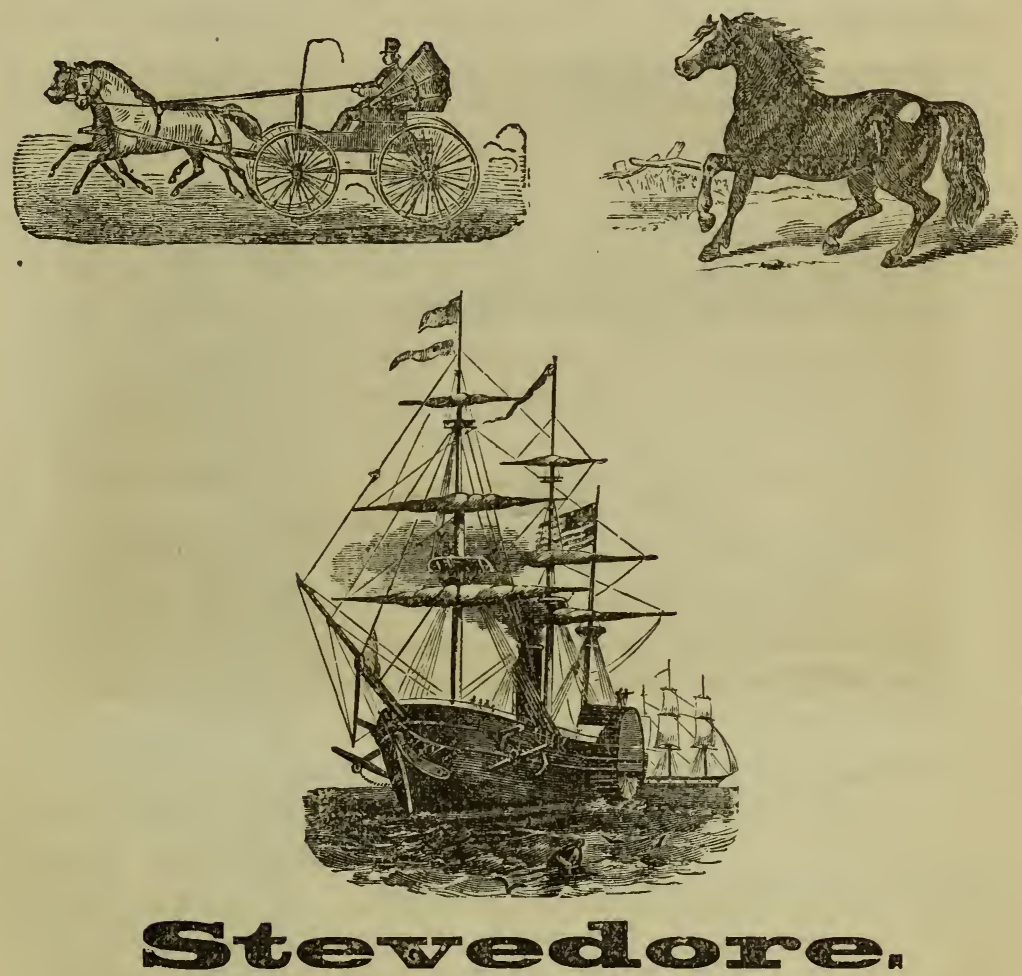

All kinds of Heavy and Light Trucking and Teaming PROMITIY ATTENDED TO.

Orders for Hauling Fish or Ballast entrusted to me will meet with prompt personal attention.

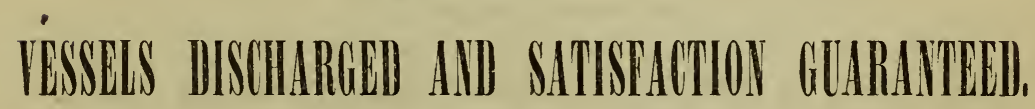
OFHICE: :

Rear 157 Front Street, and Spring, cor. of Pearce Street,
Gloucester, Mass. 
his trawls, remove his fish, rebait and reset the lines, and take care of the day's catch. Tossed on the waves in his frail dory, at greater or less distance from his vessel, he is subject to perils unknown to the fisherman of the olden time. His frail boat rides like a shell upon the surface of the sea, but in experienced hands no description of small sea craft is safer. Yet a moment of carelessness or inattention, or a slight miscalculation, may cost him his life. And a greater foe than carelessness lies in wait for its prey. The stealthy fog enwraps him in its folds, blinds his vision, cuts off all marks to guide his course, and leaves him afloat on a measureless void. Instances are on record of many a wearisome trip, of days and nights without food or water, spent in weary labor at the oars, at last to find succor from some chance ressel or by reaching a distant port; and inagination revolts from the contemplation of the hardships experienced, the hopes awakened and dispelled, and the torturing fate of the many "lost in the fog," of whose trying experiences nothing is ever kuown. The product of this fishery is divided on the same plan as that of the Georges fishery.

As the Georges fishery wanes in the closing Spring months, the sportive mackerel puts in an appearance at the far Soutl, and works northward as the season adrances. A large portion of the flect engage at once in the pursuit of this delectable fish, and follow his devious wanderings until he clisappears to an unknown haunt as winter approaches. The fleet fit away in April, going as far South as Virginia, but gradually working towards the waters of Rhode Island, and marketing their catch for the most part at New York. During. the Summer months there are two divisions of the mackerel fleet, one fishing off the shores of Massachusetts and Maine, and the other making voyages to the Bay St. Lawrence. The Southern and Shore Heets have practically abandoned the old style hook and line fishing, and are fitted with expensive seines and boats for the capture of

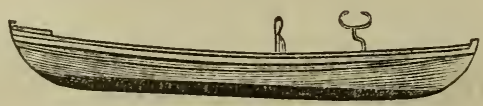

MODEL OF A SEINE BOAT.

mackerel on a wholesale scale. The success of this department is greatly dependent on the dexterity with which a school of fish can be surrounded and captured, and the employment is an exciting one. The business is an uncertain one, as the mackerel is a capricious fish, and but little calculation can be made of their move- 


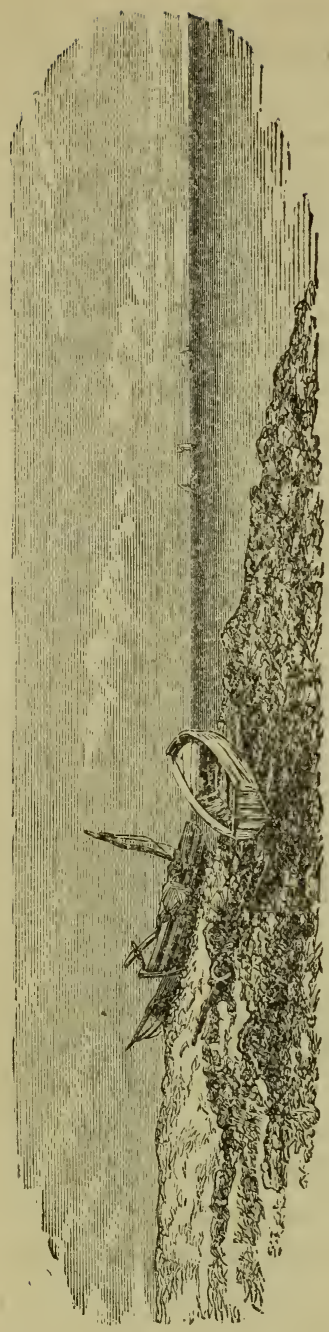

\section{ARTISTIC SERIES.}

\section{Stereascapic جูicws}

O F

COMPRISING

All the OBJECTS OF INTEREST which abound in this Charming Retreat!

\section{OLD OCEAN,}

with her white-winged fleet sailing across its pathless track;

\section{The BEACHES,}

The RUGCED COAST, The QUARRIES,

PUBLIC BUILDINGS, LIGHT-HOUSES, and CHASMS,

FORMING A SERIES WHICI DEI,IGHT ALL WHO HAVE SEEN THEM.

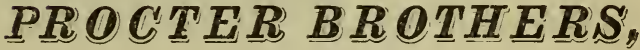

Publishers,

GLOUCESTER, (CAPE ANI,) MASS.

SIND \$2.5\%,

And let them forward you a Specimen Dozen.

\section{The Fishermen's Memorial \& Record Book}

Gives you interesting facts relative to the fisheries. How fish are caught, and where they are caught, olien time and modern time fishing, OFF HAND Slikerches, BIG Trips, STATISTICS OF THE FISHERIES, TAIES OF NARROW ESCAPES, FEarful Gales, Mara'TIME PoETry, and other matters of interest concerning this important industry. Very handsomely illustrated with original engravings. Price $\$ 1.00$ in Paper Covers; $\$ 1.50$ finely bound in Cloth. Sent anywhere on receipt of price. Agents wanted to whon exclusive territory will be given. Liberal commissions. Write for particulars.

\section{PROCTER BROS., Publishers,}

Cape Ann Advertiser Office,

GLOUCESTER, MASS, 
ments. Weeks may elapse without the discovery of the fish schooling on the surface with the proper conditions for their capture. Immense hauls, however, are sometimes made, more than can be properly dressed by the crew of the "seiner," and if no other vessel is in the vicinity to accept of a portion of the catch, large quantities are frequently thrown away through sheer inability to handle them. The seining of mackerel occasions a great destruction of immature fish, unfit for use, but such is the prolific character of the mackerel that it has never been clearly demonstrated that this method of fishing has a tendency seriously to diminish the supply. The cost of a

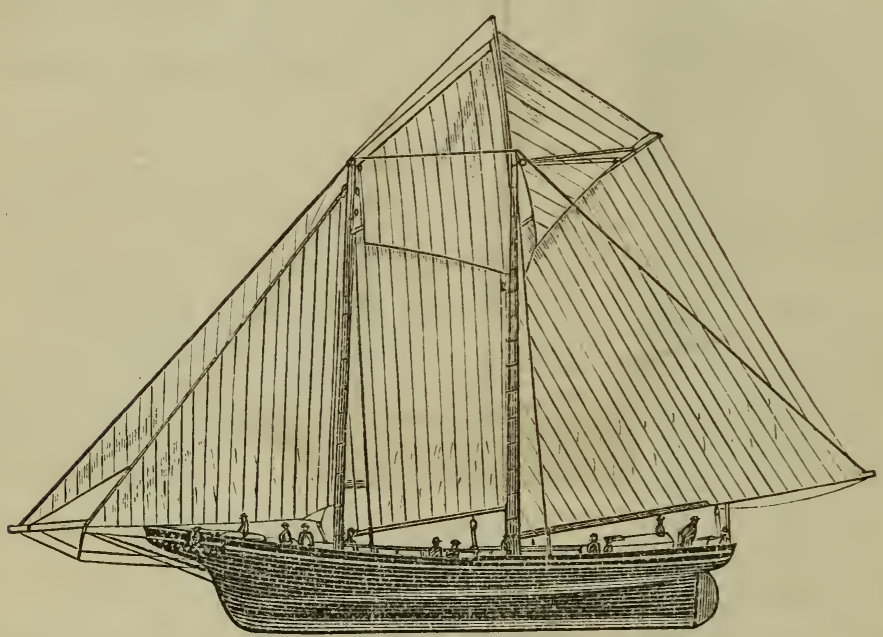

MODEL OF MACKEREL CATCHER OF 1876.

mackerel ressel, fitted for sea, is in the neighborhood of $\$ 7700$; a 200 fathom seine, of a depth of 30 fathoms, will cost $\$ 900$ additional, and a seine boat and dories $\$ 300$ more; salt, bait, lines, etc., and the necessary provisions for a five weeks' trip make the total cost, when ready for a fishing royage, \$9325. The Bay St. Lawrence mackerel fishery, once of considerable proportions, has declined largely of late year's. The seining of mackerel is found impracticable in this fishery, owing to the rocky bottom in the waters where it is followed, and the consequent destruction of seines. The number of Gloucester vesscls finding employment in the mackerel fishery in 1875 was 180 . Of these, 93 made Southern trips, 117 fished off shore, and 58 visited the Bay St. Lawrence. 618 fares were received, 133 from the South, 425 from off shore, and 60 from the Bay. 
In the mackerel fishery each man packs his own eatch in barrels provided for the purpose, putting a private mark upon the head of the barrel. On the arrival of the ressel the catch of each of the crew is culled and weighed separateiy, and packed according to grade, as Nos. 1, 2, 3 or 4 . 'The whole trip is sold together and each man is credited with one-half the ralue of his individual catch after deductions have been made for his share of the bait, preparing

- fuel, filling water, milk, and cook's share of the catch. The ressel pays for one-half of the bait, and the crew's expenses are shared equally.

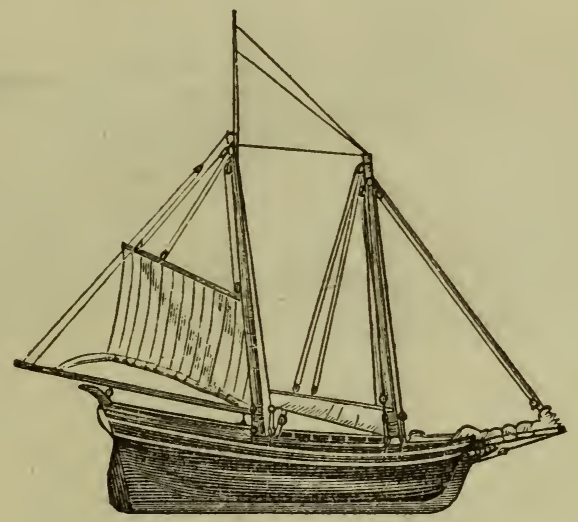

MODEL OF MARKET-BOAT.

The only other branch of the fisheries requiring mention is the off-shore fishery for codfish, hake and pollock, although considerable is done in the menhaden fishery, lobster trapping, the clam fishery, and other incidental branches of the business. The off-shore fisheryis pursued by numerous dories and a small fleet of market boats, from 20 to 50 tons burthen, using trawls and dories. The business is of considerable importance at some seasons of the year, and its total product in 1875 was $\$ 284,000$. In this fishery one-fourth of the product goes to the vessel, and the remaining three-quarters goes to the crew, in equal parts, after deducting expenses of towage and wharfage. The crew furnish their own fishing gear and provisions.

From the gross stock of all fishing trips from Gloucester, is deducted one-quarter of one per cent., which sums, with donations from the charitable at home and abroad, form a fund to relieve the distress of widows and orphans, which is constantly arising in consequence of the perils of the fisheries. 


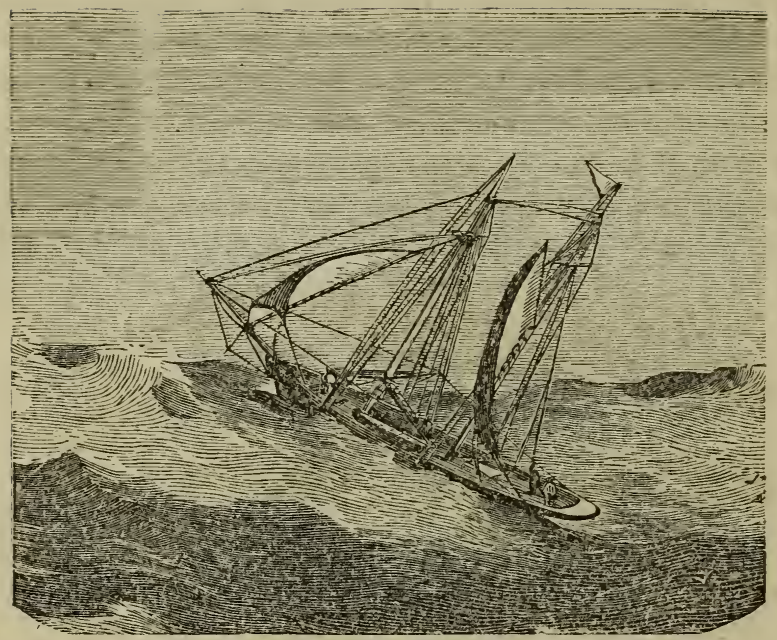

CHAPTER 5.

Tile Fishermen of To-Day-Fisming Incidents-Statistics of Catch-Big Trips.

The extent and character of the fisheries of Gloncester attract thither the fishermen of all countries, anxious to secure the advantages in the prosecution of their industry which they cannot elsewhere obtain. In most parts of the world fishermen are regarded as belonging to the lowest strata of society, and the meagre returns from their labors prevent their rising to a higher plane. Even in as enlightened a country as Canada it has been possible for a powerful firm to secure the control of a large coast territory, restricting the ownership of land to small parcels, inadequate to furnish profitable agricultural returns, compelling the inhabitants to resort to the fisheries for support. Obliged to purchase their provisions of such firms at exorbitant rates, and to dispose of their fish to the same parties at whatever price they choose to fix, whole communities are "reduced to an undisguised stage of vassalage, the want of resources and education affording them no means of resisting this oppression," says the official report. The Gloucester fisherman, if industrious and of good habits, may support his family in comfort, secure a home of his own, and the means of engaging in business in 
a small way for himself, or of smoothing the footsteps of declining years. His children enjoy the privileges of good schools, and his family are surrounded by all the elements of civilization and refinement. As the oppressed operatives of the old world find their opportunity in the manufacturing centres of New England; as the tenants of the European landholder seek an asylum on the fertile acres of the West; so the oppressed fisherman of other lands turns his eye to Gloncester as his one hope of escape from the bondage in

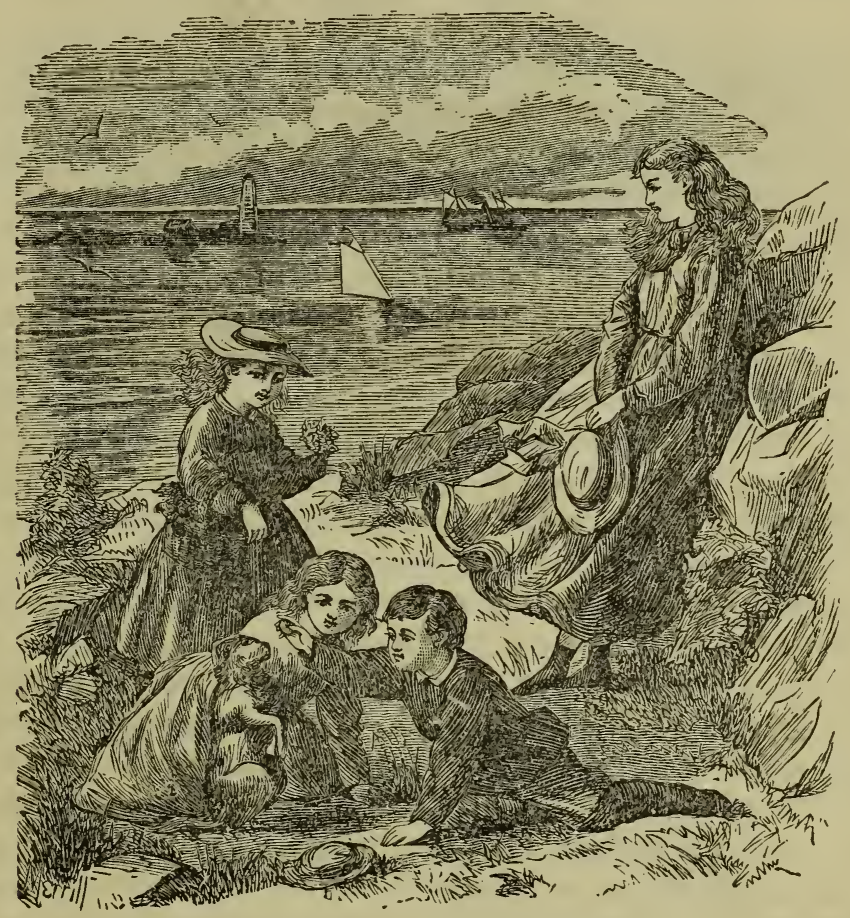

which he is held. The native born citizen makes but a small element in the catalogue of the fisheries. 'The men who sailed the fleet a quarter of a century ago are largely inclucled in the ranks of the fitters and buyers of to-dlay. Their early experience proves their best capital in conducting the business, and gires them success where others might fail.

To supply the fleet with practical fishermen large drafts are made upon the provinces of Nova Scotia and New Brunswick, and every spring sees hundreds of young men on the way from various ports 
in those maritime countries to the United States to engage in the Gloucester fisheries. The present season three-score such were lost by embarking in an unseaworthy ressel. The Nora Scotian is numbered among the best class of our fishermen. Bred to the business from early youth, discontented with the inferior craft and methods of his native land, ambitious for greater advantages than are afforded him at home, he prosecutes his calling with a zeal that assures success. If his habits are good and he makes a proper use of his opportunities, there is nothing to prevent his rising to the part ownership and command of the vessel in which he sails, and many of the smartest skippers of the fleet are of Nova Scotian birth. A considerable percentage of the fishermen of to-day are from the Western Islands, and as a general rule they are thrifty and provident, and seldom fail to become landholders after a brief residence in this country. There are also many Swedes, Norwegiaus and Danes on the fishing force, men of character and intelligence, and often of no inconsiderable culture, proving a valuable element in the community.

Such are the occupations, and such the men, of the Gloucester fishing fleet. The industry is an important one, furnishing a food supply which the nation could not well do without. The field of operations is an extensive and fruitful one, and it is tilled at great cost of vitality and sacrifice of life. The men who engage in it do not fail to find a certain pleasure in the pursuit, and it is doubtful if any considerable number of them could be induced under any circumstances to exchange it for other occupations affording more certain and profitable results. Yet to paint a life upon the ocean ware with roseate hues would be a false delineation. The fisherman's lot is one of laborious toil and exceeding hardship, taken at its best. A lot crowded with incidents, sometimes of a novel description, but too often, alas : of a sad and heart-1ending character. A few such incidents must suffice for these pages:

Dec. 16,1874, while the schooner Sultana was lying at anchor on Grand Bank, a sudden motion was felt by those on board, and it became evident that the craft was being carried through the water by some unseen and unknown power. Looking forward, it was observed that the cable was drawn taut, and that some "monster of the deep" was attached thereto, and drawing the ressel along at the rate of twelve knots an hour. Soon they obtained positive evidence, as a mammoth whale came to the surface to blow, haring the anchor of the ressel hooked either into his jaw or blow-hole. There was also another whale which swam near, evidently greatly astonished at 


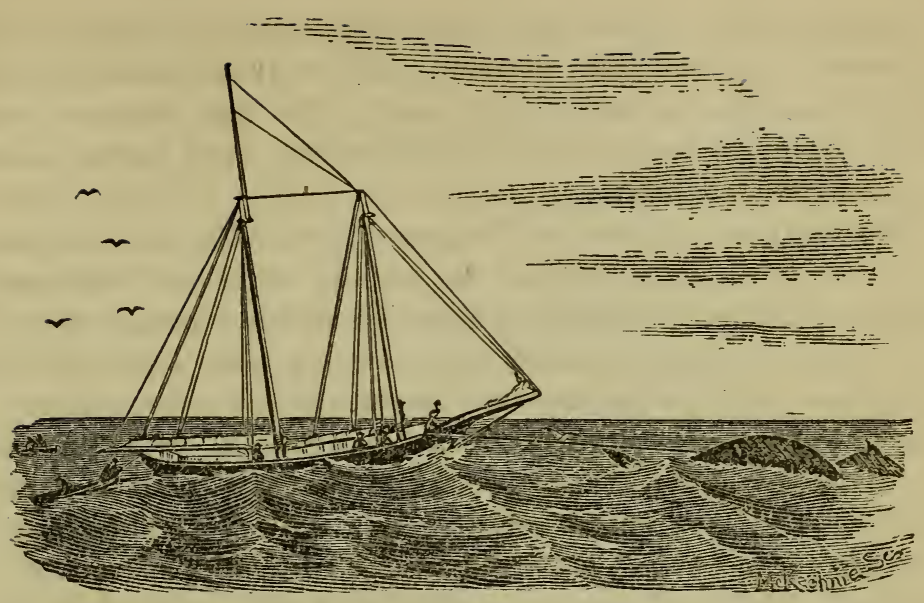

TOWED BY A WHALE.

the predicament of his companion. The men on board one of the dories, which had just returned from risiting their trawls, had barely time to make fast their painter ere the vessel started. Another dory, with two men, was at some distance, also visiting their trawls. The captain stood ready with axe in hand, in case of emergency, and allowed the whale to tow them some distance; but not wishing to lose sight of the men in the dory, was obliged to cut the cableotherwise he might have succeeded in capturing the whale. The above spirited picture gives a good idea of the Sultana in tow. It was drawn by Rory McDonald, steward of the vessel.

The schooner Sarah C. Pyle, Capt. Richard Warren, was struck by a cross sea and capsized Jan. 30, 1870. The crew found safety by clinging to the sides of the vessel, until one of their number was able to cut away the main shrouds with a pocket-knife, when the vessel righted, nearly full of water. The foremast was cut away and a jury mast rigged with the foreboom, and such progress as was possible was made in a westerly direction. For eight days the men were obliged to cook their food in sea water, their water casks having been lost, and to melt ice to furnish drink. At the end of that time they encountered a ressel and were furnished with water and other necessaries. Five of the crew were transferred to the vessel, but the skipper and four men remained on the wreck, determined to get it into port. In this condition they encountered a terrific gale, of three days' duration, and were blown off seawards a distance of two hundred and forty-five miles. Even then they remained undaunted 
by danger and firm in their intention of rescuing the property under their charge, and declined an offer to be taken off. The wreck was towed into a New Jersey port Feb. 13th, two weeks after the disaster, - a fortnight crowded with great hardship and danger to the men so faithful to duty.

John Mayuard, of New London, and William Corthell, of Lyme, Conn., of schooner Gilson Carman, left that vessel on Georges, on Wednesday, Mar. 17, 1869, in a dory, to haul their trawbs, and while doing so, a very heavy thunder squall sprang up, driving them from the banks. They had at the time several halibut and from sixty to serenty codfish, which they had to throw orerboard, with the exception of one, which they retained to eat. After eating a little it made them sick, and they were obliged to throw it away. On Thursday. night they saw a vessel, but were unable to attract her attention; were drifted about all day Friday and Friday night, without anything to eat. On Saturday noorning a duck lit in the vicinity of the boat, which they managed to kill, and ate it raw. On Saturday night, when they had nearly given up the idea of being saved, they made a light a few miles ahead. They immediately pulled for it, when it proved to be the schooner Henry Clay. During the time they were in the boat they had a steady storm of rain and snow, and were frequently capsized, but with the aid of a bucket they managed to keep the boat clear of water. Corthell had his feet badly frozen. Maynard's arm was badly chafed and swollen, and both suffered greatly.

Sch. Neptune's Bride was wrecked at Malcomb's Ledge, Me., Sept. 22,1860 . Twelve of her fourteen men found a watery grave by the swamping of the boat in which they sought to reach the shore. One other, Henry Johnson, was enabled to regain the boat. She was full of water, but fortunately there was a bucket in her, and a coil of rope. With the former he commenced bailing, and by dint of hard labor managed to free her, although she was continually taking in water. A hogshead tub from the vessel had drifted across the boat amidships. This he secured with his rope, and that made the boat ride more easily. When he got tired of bailing the boat he would crawl into the tub, and when that got full of water he would commence bailing the boat again. He knew not whither he was drifting, and became so utterly exhausted that, long ere daylight dawned, he fell asleep. At noon-time a Belfast schooner sighted the craft, bore down to her, and her single passenger was received on board and kindly cared for. One other of the crew, named Marsh, secured a resting place at the foremast-head, where for eighteen hours he en- 
dured greater agonies than death could inflict. The surging waters reached to his waist, while the pitiless rain beat upon his unprotected head, and the pangs of thirst and hunger clamored that he should cease the unequal strife and seek oblivion in the seething flood. But the instinct of self-preservation was strong, and he maintained his position until his feet were chafed and raw, and delirium set in. His critical position was at last discovered by two fishermen on Seal Island, and he was taken off and tenderly cared for until reason resumed its throne and he was able to take passage for home.

Subject to perils like these, and hardships greater than pen can describe or imagination conceive, the fisherman plys his busy trade. Through his labors mainly Gloucester has grown from a population of 6350 and a valuation of one million dollars in 1840 to a present population of 16,754 and a valuation exceeding nine millions, showing in the brief period of thirty-five years an increase of 264 per cent. in population, 853 per cent. in valuation, $3581-2$ per cent. in dwellings, 442 per cent. in wharves, and 213 per cent. in vessels. Through his skilled operations, and the advantages taken of his labors, the fishing business of Gloucester has grown from an enterprise of secondary importance to rank among the valuable producing interests of the country. Less than thirty years ago, in 1847, the total value of the fishery products of Gloucester amounted to $\$ 589$,354. Last year the production of the Gloucester fleet was as follows :

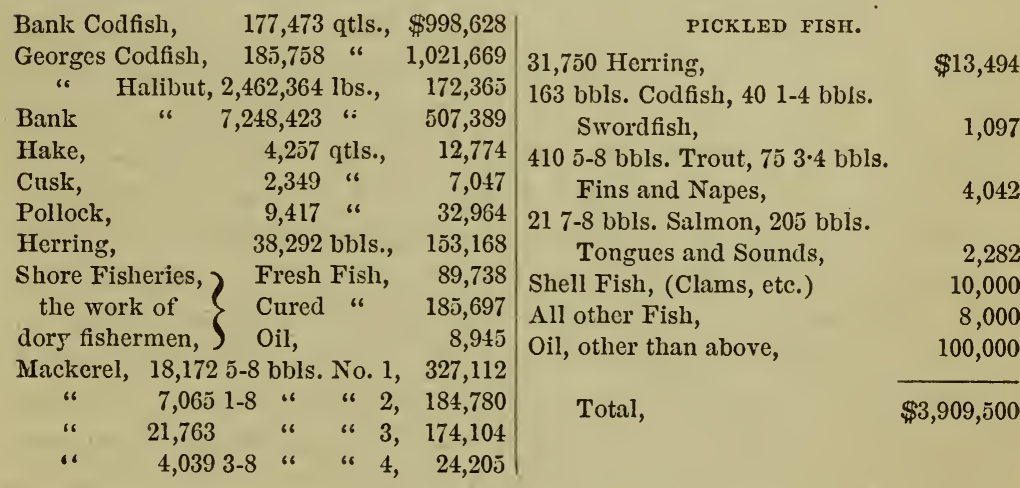

The business is not uniformly successful. More largely than any other occupation, probably, it is subject to circumstances over which the men engaged in it can have but little control. The best results are most likely to be secured by the skipper who understands fully the habits and probable movements of the fish, and who displays the 
best judgment in conducting the royage, but not unfrequently the wisest calculations fail to achieve success, and it often happens that one vessel will come in with a full load while another, with apparently equal chances for securing a fare, will be obliged to return with a meagre catch.

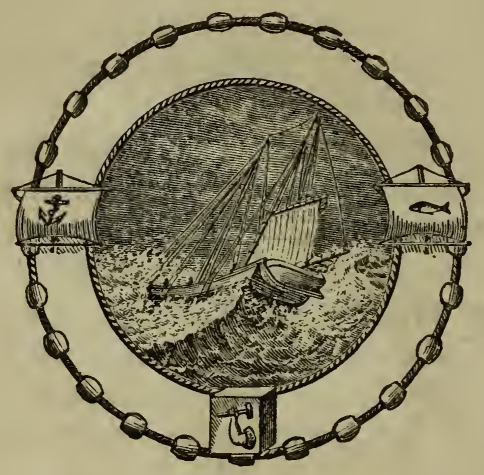

The largest fare of fresh halibut erer landed at Gloucester was brought in by schooner Centennial, Mrarch 30, 1876, after an absence in the Grand Bank fishery of only three weeks. Her catch weighed off 129,557 pounds. 'The largest halibut fare from Georges Bank ever landed was $65,000 \mathrm{lbs}$., by sch. Pioneer, after a three weeks' trip, the conk receiving $\$ 167$ and the "high line" (or man making the best catch) $\$ 181$ as the result of the trip. The largest codfish fare from Georges was that of the sch. Samuel R. Lane, in 1875, weighing $123,115 \mathrm{lbs}$. The largest stock ever made on a Georges trip was $\$ 2824.55$, by the sch. Everett Steele, in 1865 . The largest codfish fare from the Banks was 240,000 lbs., by the sch. Grand Master, in 1875. The largest stock in this fishery was made by sch. Reunion, in twelve weeks in 1868 , her catch being $153,044 \mathrm{lbs}$. halibut and 23,875 lbs. codfish, netting $\$ 8354$. Sch. Gertie E. Foster landed last year $668,517 \mathrm{lbs}$. halibut, and 19,220 lbs. codfish, stocking $\$ 26,071$ .56 in eleven months; her master, Capt. Edward Morris, stocked $\$ 64,769.78$ in the years 1873-4-5. Sch. Alfred Walen made four trips in eighty-six days last year, taking $300,000 \mathrm{lbs}$. halibut and stocking $\$ 10,900$ in that period. The highest price ever brought by a halibut trip was 21 cts. per lb. for white and 14 cts. per lb. for gray for $9000 \mathrm{lbs}$. brought in by sch. T. L. Mayo. 


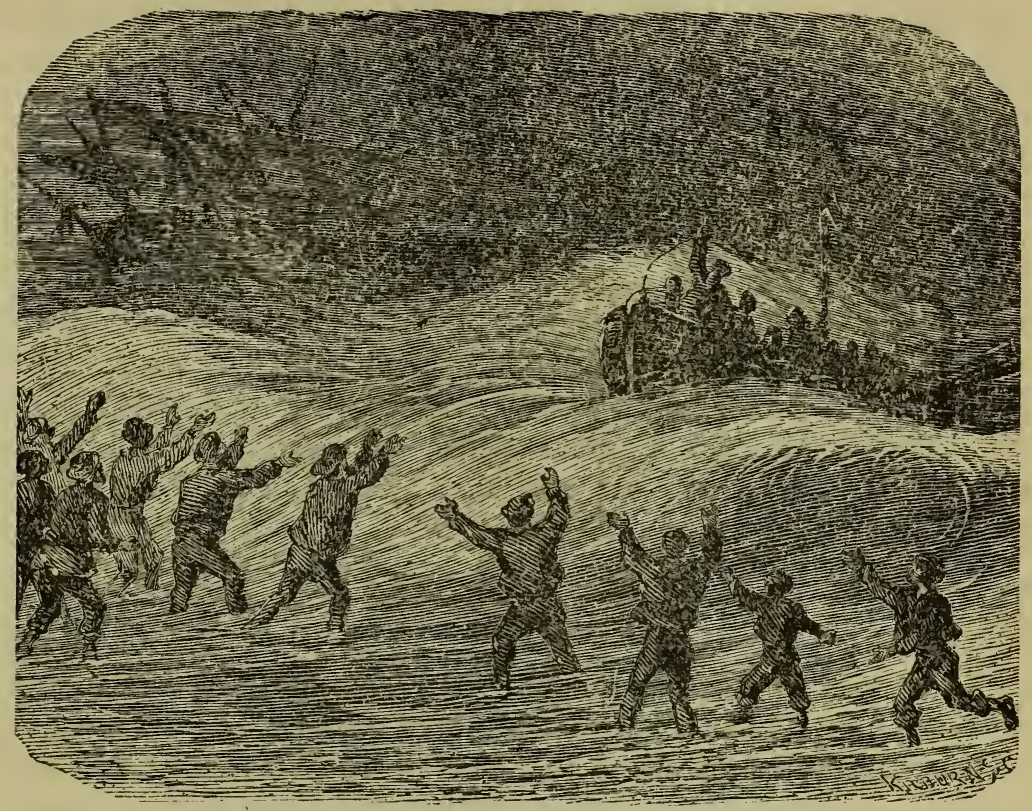

\section{CHAPTER 6.}

Shipwrecis and Fishing Losses.-Table of Gloucestei Fishixg Losses From 1830 to 1876.

It might almost be said that every projection of land or rock along the rugged promontory on which the city is seated, has its direful tale of death and disaster to relate, while not a few take their local designations from sad scenes of shipwreck of which they have been the unmoved witnesses. From Norman's Woe on the extreme South, towards whose rough reef many a "sheeted ghost" has swept since the disaster which tradition asserts gave it its name, and whence between the fitful gusts may still be heard

"the sound of the trampling surf

On the rocks and the hard sea sand;"

past 'Thacher's Island, where Anthony Thacher and his good-wife were so strangely reunited on a summer morning in 1635 ; to Gallop's Folly on the North; all along the coast are barren islets and jagged rocks with each its separate tale of disaster to narrate. 
Sometimes unnoticed and unknown, often in sight of anxious watchers impotent to help, not unfrequently despite the bravest efforts for their succor, men have gone down into the jaws of death, while the dashing waves have sung their requiem. In 1796 the ship Industry of Boston was wrecked at Little Good Harbor Beach, and all her crew met a watery grave, with none but the all-seeing eye to witness their desperate struggles with the storm-king. In 1829 the ship Persia was wrecked on Eastern Point, and all her crew were lost, while the unconscious town slept, nor dreamed of the dark tragedy enacting so near at hand. In 1839 a score of men were lost in a terrible storm that swept across the harbor. And oft has the despairing mariner, clinging to his insecure foothold on stranded wreck, been snatched from the yawning gulf that waited to cover him, by the efforts of brave men willing to risk their lives for his succor.

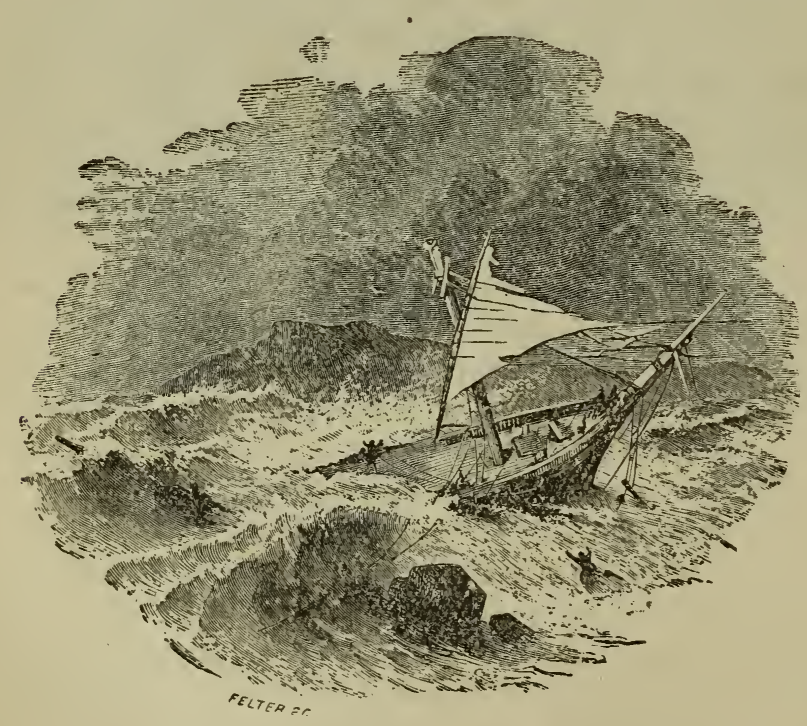

Of late years the improvements in marine architecture and equipment have rendered disasters less frequent, and the additional facilities for saving life, furnished mainly by the Massachusetts Humane Society, have greatly lessened the perils of mariners exposed to the dangers of a lee shore. To-day coastwise navigation is comparatively free from danger, if duly heeding the warning beacons of the Signal Service Corps, and it is to be hoped that our maritime ports 
may never again witness the wholesale destruction of life which they have so often seen in the years that are past.

And while the loss of stranger crews upon her shores has so often awakened sympathy and regret, Gloucester has constantly been called upon to mourn her own sons who hare gone down at sea. The ambition of her youth has not been circumscribed by the narrow confines of her fishing ventures or local commerce. Gloucester men have sailed all seas, and their bones have whitened beneath the waters of both hemispheres. Many a sailor and officer and ship-master has graduated from her fishing craft from earlier to latest days, and many a home has been darkened by the loss of husband or father or brother upon some distant royage. Whole families of sons, taking to the sea one after another, have perished thus. The dark days of the Revolution, brightened by the loyalty of Gloucester sailors and fishers, took on more sombre guise from the sad fate of many of the number. Sixty wires were made widlows and scores of children fatherless, by the loss of the privateer ship Gloncester in 1777. The Cumberland carried down many of "the flower of the town" in 1778 , and a large number were lost in the Tempest in 1782 .

The history of the Gloucester fisheries has been written in tears. No other industry by sea or land, sustains such a drain upon its resources and employes. Other callings may shorten life, but none show such constant and wholesale destruction. The men who go out upon the Banks take their lives in their hands as surely as he who goes into battle; nay, the proportion of fatal casualties upon the battle-field is much smaller than in this perilous calling. The growing importance of the business has not been accompanied by greater exemption from disaster and death. In the last 46 years the aggregate fishing losses of Gloucester have amounted to 333 vessels, of a value of $\$ 1,361,300$, and 1590 lives, or an average annual loss of 7 vessels, valued at $\$ 27,420$, and 35 lives. For the past five years the average annual loss has been 18 vessels, $\$ 81,860$, and 114 lives. And these figures, so far as loss of property is concerned, represent only the total losses of Gloucester ressels, and would be largely augmented if we added the losses of cables and anchors and spars, the damages by collision and stranding, and other disasters resulting only in a partial loss.

Think of a business in which, outside of ordinary depreciation of wear and tear, and added to all other expenses and out-goes, onefiftieth of its capital and three per cent. of its employes are swept away annually by disaster. In May, 1875, sixty persons lost their 
lives by the burning of a church in South Holjoke, Mass. A month later the floods in the valley of the Garonne, in France, swept away fifteen million dollars of property and many lives. In 1874 twentythree lives were lost in a burning mill at Fall River, Mass. The Revere Railroad disaster in 1871 resulted in the loss of twenty-nine lives, and the bruising and scalding of many others. The Mill Rirer (Mass.) flood of 1874 swept amay one hundred and forty lives and much valuable property. 'The history of these and many other disasters of like character has been scattered broadcast by the fleetwinged press, and awakened the sympathies of the world. But considering the extent of country and valuation drawn from, these losses dwindle to modest dimensions compared with the fishing losses of Gloucester. In a single rear (1873) thirty-one of her ressels sailed to return no more, and 174 of her fishermen were laid in an ocean grave. In a single storm, "The Lord's Day Gale " of August 24 of that year, nine Gloucester ressels went do $\pi n$ before the dreadful blast, and 128 Gloucester mariners met their doom.

On the next page will be found a table showing the loss of life and property annually in the Gloucester Fisheries since 1830.

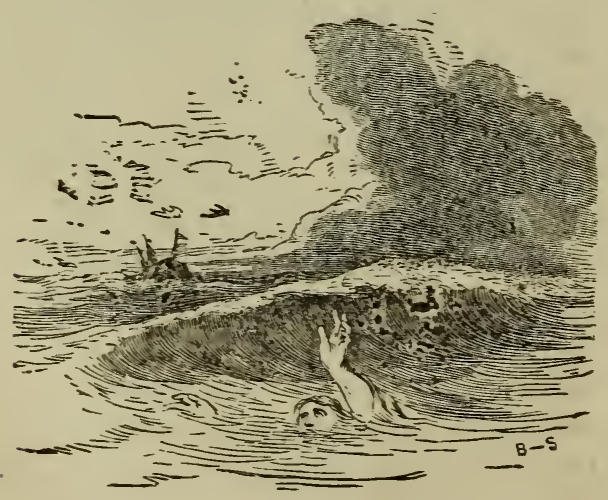


TABLE OF LOSSES.

\begin{tabular}{|c|c|c|c|c|}
\hline YEAR. & MEN. & Vessels. & VALUATION. & INSURANCE \\
\hline 1830 & 7 & 3 & $\$ 5,600$ & $\$ 3,100$ \\
\hline 1832 & & 1 & 1,000 & \\
\hline 1833 & & 1 & 1,000 & \\
\hline 1834 & 4 & 1 & 1,500 & \\
\hline 1836 & & 1 & 1,000 & \\
\hline 1837 & 24 & 5 & 10,100 & 5,300 \\
\hline 1838 & 4 & 4 & 7,100 & 3,000 \\
\hline 1839 & 4 & 2 & 3,800 & 3,150 \\
\hline 1840 & 6 & 2 & 3,800 & 1,400 \\
\hline 1841 & 8 & 2 & 2,725 & 150 \\
\hline $18+2$ & & 3 & 2,000 & 150 \\
\hline 1843 & 10 & 3 & 6,000 & 2,000 \\
\hline 1844 & 7 & 3 & 4,800 & 1,500 \\
\hline 1845 & 7 & 4 & 4,500 & 2,350 \\
\hline 1846 & 15 & 3 & 4,900 & 3,600 \\
\hline 1847 & & 3 & 6,200 & 4,450 \\
\hline 1849 & 10 & 2 & 3,500 & 2,200 \\
\hline 1850 & 40 & 12 & 15,500 & 12,900 \\
\hline 1851 & 32 & 9 & 17,300 & 14,800 \\
\hline 1852 & 32 & 13 & 41,800 & 36,700 \\
\hline 1853 & & 3 & 10,000 & 8,800 \\
\hline 1854 & 26 & 4 & 14,600 & 12,650 \\
\hline 1855 & 21 & 7 & 20,900 & 16,100 \\
\hline 1856 & 2 & 6 & 14,400 & 11,475 \\
\hline 1857 & 9 & 5 & 11,500 & 7,750 \\
\hline 1858 & 42 & 7 & 18,700 & 8,537 \\
\hline 1859 & 36 & 6 & 21,900 & 16,475 \\
\hline 1860 & 73 & 7 & 26,350 & 20,494 \\
\hline 1861 & 44 & 15 & 54,250 & 43,880 \\
\hline 1862 & 162 & 19 & 66,500 & 53,225 \\
\hline 1863 & 6 & 9 & 38,000 & 8,300 \\
\hline 1864 & 85 & 13 & 79,900 & 50,525 \\
\hline 1865 & 11 & 8 & 40,300 & 32,400 \\
\hline 1866 & 26 & 15 & $114,2 \tilde{\jmath} 0$ & 82,095 \\
\hline 1867 & 66 & 11 & 82,675 & 59,069 \\
\hline 1868 & 40 & 4 & 35,000 & 28,150 \\
\hline 1869 & 66 & 16 & 83,450 & 54,137 \\
\hline 1870 & 97 & 13 & 75,200 & 59,907 \\
\hline 1871 & 140 & 19 & 89,000 & 77,259 \\
\hline 1872 & 63 & 12 & 55,400 & 49,121 \\
\hline 1873 & 174 & 31 & 118,700 & 100,918 \\
\hline 1874 & 68 & 10 & 49,100 & 44,975 \\
\hline 1875 & 123 & 16 & 97,100 & 81,726 \\
\hline Total, & 1590 & 333 & $\$ 1,361,300$ & $\$ 1,024,718$ \\
\hline
\end{tabular}




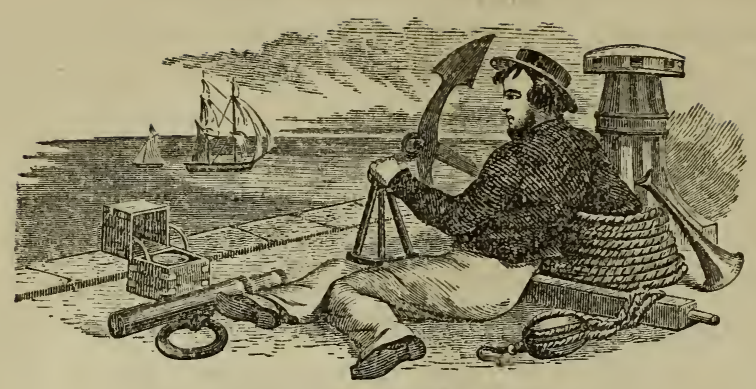

CHAPTER 7.

\section{Commerce of Gloucester.}

While Gloucester at the present time is undoubtedly the largest seat of the fisheries in the world, it has not always occupied that leading position in the United States. Marblehead was for many years her competitor and greatly her superior. Fifty or sixty years ago the fisheries was not the leading pursuit of Gloucester. No doubt, years before, the fisheries exceeded the foreign commerce in importance, but from 1783 to 1845 the fishing business had declined from its former importance, and the Bank fishery, once so important, had almost faded out of existence, so much so that some years less than half a dozen ressels were engaged in this fishery.

But until 1860 Gloncester was largely engaged in foreign commerce. It had two or three large mercantile houses, and ships, barques, brigs and schooners running to the East Indies, South America, Europe, Dutch Guinea and the West Indies. The harbor of Gloucester has seen the arrivals from every part of the globe, and its wharves and storehouses have held the products of every clime upon the eartll. But its commercial interests aside from the West Indies (a trade in which for many years it liad a large share) was from 1810 to 1860 , a period of fifty years, mainly directed to Paramaribo or Surinam in Dutch Guinea. In various portions of this period it had nearly the whole American trade to that port. Its importations of sugar, molasses and cocoa were some jears nearly four hundred thousand dollars, and its exports two hundred thousand. About 1860 this trade was transferred to Boston, and since that period the foreign commerce of Gloucester has declined.

But two or three new branches of commerce arose to take the place of this Surinam business. Among these are the Nova Scotia, 
Newfoundland and Salt trades. The latter business has attained great proportions, and this ancient port shows more than ever the presence of great ships and barques, sometimes as many as six being in port at one time. Besides this important business Gloucester carries on quite a large business with the British Provinces, and its importation of codfish, herring, wood and lumber are very important. These branches of business are likely to increase in the future, (especially the salt trade), and this ancient seaport may yet show a greater amount of foreign shipping at its wharves than it did in ancient times.

It will be seen from these statements that not only as a fishing port has Gloucester been celebrated, but as a seat of foreign commerce it has occupied a very respectable position. But Boston gradually attracted the business of all the lesser ports such as Salem, Newburyport and Gloucester, and now it looks almost as if the trade of Boston itself was to be swallowed up by New York, Philadelphia and Baltimore, who govern exports to Boston.

The total value of the imports into the District of Gloucester for 1875 was $\$ 107,610$, as follows: salt, $\$ 65,531$; codfish, $\$ 23,100$; fresh herring, $\$ 6,833$; salt do., $\$ 1300$; firewood, $\$ 6575$; potatoes, $\$ 2008$; cigars, $\$ 746$; coal, $\$ 620$; fish oil, $\$ 350$; eggs, $\$ 169$; other fish, $\$ 174$; miscellaneous, $\$ 204$.

At an carlier period of the fisheries, the ressels fitted for the Banks, then took their fares to Spain, bringing return cargoes of salt, \&c. Since that time there were no direct importations of any note until the receipt of a ship load June 1, 1861, followed by another ship load June 5th of the same year, both from Liverpool, Eng. These cargoes amounted to 8507 hogsheads, of an invoiced value of $\$ 4905$. In $1870,20,1362-3$ hhds. of Liverpool salt, valued at $\$ 8673$, and 24,879 1-2 hhds. of Cadiz salt, valued at $\$ 13,910$, were imported in seven brigs and ten barks. In 1875 the importations were $\mathbf{7 4}$,032 hhds. from Cadiz, 20,480 hhds. from Liverpool, 10,966 hhds. from Trapani, and 3,008 hhds. from Turk's Island. Total importations, 108,486 hhds. in 2 ships, 12 barks, 12 brigs, and 16 three. masted schooners. Of these 42 ressels, 34 were under the American, 5 under the English, and 3 under the Austrian flag. The amount of salt used in the curing of fish was 106,245 hhds. 


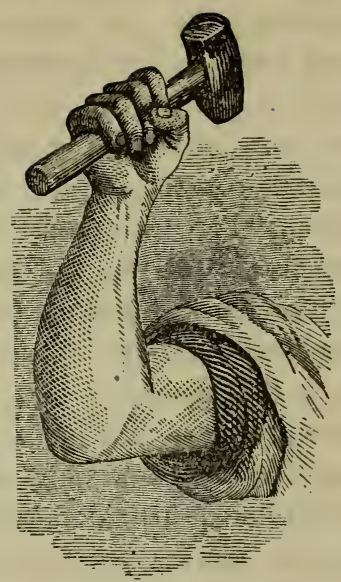

\section{CHAPTER 8.}

'The Granite Industry of Cape Ann.

While the fisheries furnish an exhaustless field for enterprise, Cape Ann has yet another branch of productive industry in which the most active operations make but small apparent dimunition of the supply. Her hills and fields are marked by the outcroppings of the huge ledges which underlie them, mines of wealth as truly as those of Ophir, whose products have been freely yielded for the construction and ornamentation of the temples of the nineteenth century. Her rocks are granite, of a beautiful, dark color, easily wrought into any desirable shape, and susceptible of a high polish.

From the earliest times the rocks of the Cape were made to serve the necessities of the inhabitants, in the construction of their buildings and fences, but their merchantable value was a thing of slow growth. The rapid growth of the fishing business in the last century, and the lack of harbor accommodations on the North side of the Cape, opened a new use for this abundant material, in the mooring of the diminutive craft of those days off shore. Flat blocks of granite, about six feet square, and from ten to fifteen inches in thickness, were prepared by cutting a hole fifteen inches in diameter in the centre, into which an oak butt; having the roots attached, was inserted. The stone and spar were then dropped at a proper distance from the shore, and used for the securing of fishing craft, affording a safe mooring except in heavy easterly gales, when it was found necessary 
to secure greater protection by seeking a harbor elsewhere. It was not until 1824, however, that the business of working stone for shipment reached any considerable importance. In that year a Mr. Bates of Quincy came to Sandy Bay and leased a ledge, inaugurating an industry that soon had a rapid growth, and became the second business in importance on the Cape. Not long after quarries were opened at Annisquam, where an extensive business was carried on for many years, furnishing stone for the fortifications erected in Boston harbor, and for wharf and building purposes. These quarries were long since abandoned, and the business is not followed to any considerable extent at this point.

The flourishing granite industry at Pigeon Core, now embraced within the lines of Rockport, had its origin in 1827, when Messis. Ezra Eames and Beniah Colburn opened a quarry there, by the seaside, and soon found a ready market for their products for building and cemetery purposes. Their first year's business is said to have resulted in a net loss of fifteen dollars, but the government became their patron, and a profitable industry was soon leveloped. Their first quarry was abandoned when it reached the level of the sea, but new ledges were opened, and changes made in the firm from time to time, until it developed into a wealthy corporation, under the name of the Rockport Granite Company, who now own a valuable property and conduct an extensire business. The Pigeon Hill Granite Company also have an extensive trade, and was the first in Rockport to build a railroad from the quarry to its wharres to facilitate the transportation of rough stone for dressing and shipment.

The extensive granite industry at Bay View is the outgrowth of a modest beginning in 1848 , when a quarry was opened to supply the stone for building a bridge across Hodglins Cove. The first stone shipped from this point was in 1849 , but no considerable business was done in this line until 1853, when Mr. Beniah Colburn and Mr. William Torrey purchased the quarries and commenced active operations, which were continued, under various firms, for a dozen years. These quarries were not worked to any extent from 1865 until 1869 , when, on the suggestion of General Butler, who had erected a summer seat in the immediate vicinity, that it was too valuable a property to lie idle, it was purchased by Col. Jonas H. French and others, and a corporation organized, with a working capital of about $\$ 125,000$, to conduct the business, under the name of Cape Ann Granite Company. Since the latter date an extensive business has been carried on, large additions having been made to the landed 
possessions of the corporation, and great improvements made in the property. A railroad has been constructed, on which a locomotive and eighteen platform cars are employed in the transportation of stone from the quarries to the wharves, a distance of a mile and a quarter; the wharves have been extended and the harbor protected, and the population and property of the village more than doubled. The securing of the contract to furnish stone for the new Boston Post Office gave an impetus to this company which at once placed it in, the front rank in the granite industry of the old Bay State. The largest granite blocks ever quarried in this country were furnished by this company, for the Scott Monument at Washington, D. C., . one of the blocks, for the foundation, being twenty-eight feet two inches long, by eighteen feet eight inches wide, and three feet two and three-eighths high, weighing nearly one hundred and fifty-one tons. The company employ two hundred and serenty-five men, and use four steam engines for hoisting and drilling purposes.

The stone business at Lanesville antedates the operations at Bay View, and is still carried on on an extensive scale. The changes in the management of this business at this village have been numerous within the past quarter of a century. There are now three firms engaged in it, the Lanesville Granite Company, the Bay State Granite Company, and Messis. George Barker \& Co., the latter being a branch of a firm also doing business at Quincy. These companies. represent a capital of about $\$ 110,000$.

The only other part of the Cape where the business is carried on: to any considerable extent is at West Gloucester, where the quarrying of stone was commenced by the Gloucester Granite Company, a corporation with a handsome capital, which was exhansted in the heavy outlays required in the construction of a wharf, railway and buildings, and in working the surface drift and developing the value of the quarry. This property has since passed into the hands of other parties, who are building up a successful and profitable trade.

The granite. business combines with the fisheries in attracting settlers from abroad, the number of native-born citizens engaged in either being but a small per cent. of the whole number employed. The two branches of industry however serve to attract totally different classes of residents, the fishing business drawing its workmen principally from Maine, the British Provinces and the Western Islands, while the granite industry brings its quarrymen from "the Gem of the Sea," its teamsters from the Granite State, and its. skilled hammerers from the heather hills of Scotland. 


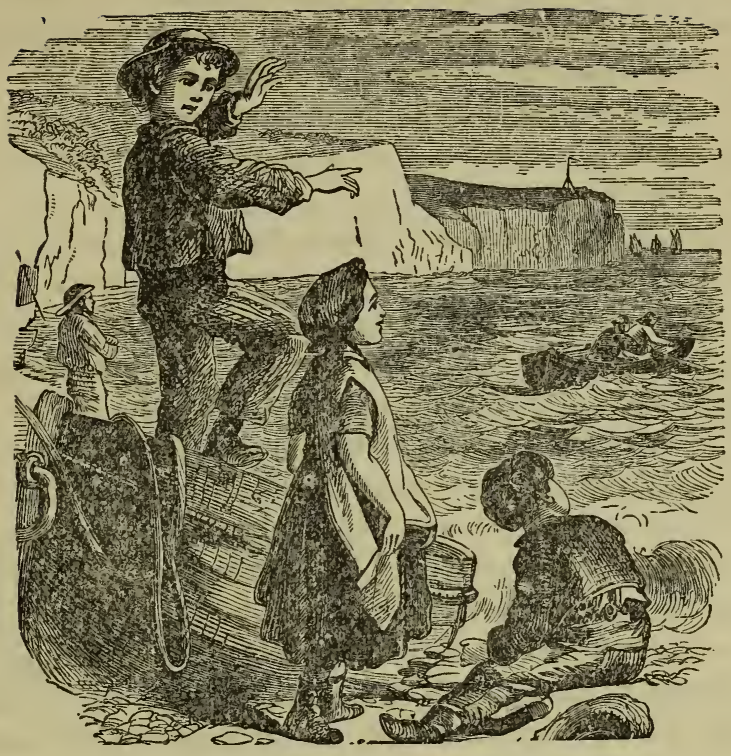

CHAPTER 9.

Summer Attractions of Cape Axx.

Of the sea-side places of summer sojournings and recreation on our Atlantic coast, from Eastport to Cape May, including Mt. Desert, Old Orchard Beach, Hampton Beach, Newport, Long Branch, and Atlantic City, none equal in all particulars united, the promontory on which are located the city and parishes of Gloucester, and the villages of Rockport and Pigeon Cove.

As to altitude Mt. Desert is pre-eminent; but the general elevation of Cape Ann, presented in hundreds of hills, ledges, bluffs, and precipices, and in huge castellated and rounded rocks, is sufficient for broad and various views. Besides, from the top of Thompson's Mountain, in the West Parish of Gloucester, may be seen, on any fair day, Bunker Hill Monument, and the domes of Wachusett, Monadnock, Gunstock and Agamenticus. From Meeting-house Hill, in the same parish, Butler's Hill at Annisquam, Pigeon Hill, Pool's Hill and Great Hill, at Pigeon Cove and Rockport, and Lookont Hill and Governor's Hill at Gloucester Harbor, the vision takes in more or less of Massachusetts Bay, on the south side of the Cape; and on 
the north side, Ipswich Bay and the line of coast, backed by the nearer hills and towns of Massachusetts and New Hampshire, extending from Essex, Ipswich and Newburyport, far northeastward to the hills below Agamenticus and the ancient town of York, in Maine. It will be observed, of course, that within this compass of the eye, something more than a score of miles from the northern shore of the Cape, lie the Isles of Shoals.

As to stretch of sand, Old Orchard Beach is a marvel, but Little Good Harbor Beach and Long Beach, on the south side of the Cape, near the boundary between Gloncester and Rockport, and Coffin's Beach on the Ipswich Bay border of the West Parish of Gloucester, are more than satisfactory, as hard, smooth floors for the wheels of carriages or the feet of pedestrians; or for the accommodation of picnics and bathing parties; especially since they are placed in contrast with granite boulders and ledges, and with pastures of sweet herbage, bayberry and wild-rose bushes, close by them, and with rugged hills but a little farther off.

As an area for sea-side rest and pleasure and for country shade and enjoyment, at the same time, Cape Ann is incomparable. Here, the tourists, the summer cottages, and the visitors occupying the hotels, are delighted with the remarkable blending of the marine with the 'ural. If they would sail, there are harbors all around the indented shore, from any one of which they may go forth upon the sea within sight of pleasant cities and villages, picturesque heights and intervening vales, with wood and orchard and field. From the harbor of Gloucester city, Fresh Water Cove, or Magnolia, the trip may be to Salem, Baker's Island, Manchester, Lowell Island, Marblehead, or, by rounding Eastern Point, to Thacher's Island. From Rockport, Pigeon Cove, Folly Cove, Lanesville, Bay View or Annisquam, it may be to Chebacco River, Ipswich River, Plum Island, Newburyport, Boar's Head, Portsmouth, the Isles of Shoals, or, by doubling the southern horn of the Cape and Straitsmouth Island, to Gloucester Harbor; or, by the way of 'Squam River and the Cut, to Gloucester Harbor and Massachusetts Bay. If they would ride, from whatever starting place, the most popular route is the "road 'round the Cape." On almost every rod of this highway of fifteen miles, the waves of ocean, bay, or inlet, are within sight.

Branching from this principal road are other roads extending to or passing through villages or sequestered neighborhoods near the sea, or near the coves here and there. The ride may be varied from day to day by turning into these by-ways, and so driving to Bass Rocks, 


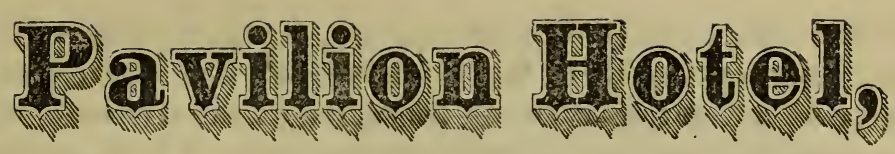

GLOUCESTER, MASS.

Delightfully situated in the centre of Pavilion Beach where a full view of Gloucester Harbor is obtained, forming one of the coolest retreats upon the coast. Every facility for boating, fishing, riding, bathing, etc. Charming scenery on every hand. Good Livery stable in the vicinity, and every attention paid to the comfort of guests.

For terms, etc., address,

G. S. SEAVEY, Proprietor.
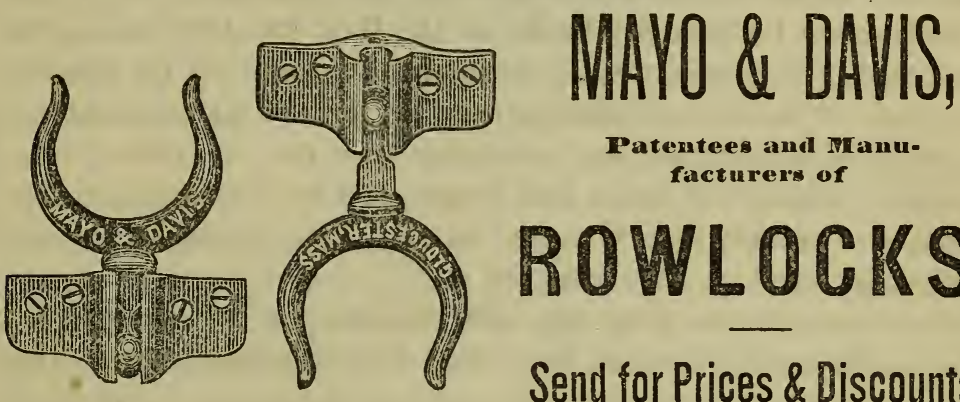

Patentees and MIanufacturers of

ROWLOCKS.

Send for Prices \& Discounts.

\section{Fishing Establishments in Gloucester.}

The Centennial Year, 1876, finds thirty-eight fishing firms and establishments in Gloucester Harbor, owning and fitting out 361 vessels, as follows :

D. C. \& H. Babson,

Clark \& Somes,

George Dennis \& Co.,

Cunningham \& Thompson,

Dennis \& Ayer,

Joseph Friend,

Sidney Friend \& Bro.,

George Garland,

Benj. Haskell \& Sons,

Samuel Haskell,

Harvey Knowlton, Jr.,

Samuel Lane \& Bro.,

Leighton \& Co.,

David Low \& Co.,

Maddocks \& Co.,

James Mausfield \& Sons,

McKenzie, Harly \& Co.,

George Norwood \& Son,

Charles Parkhurst,
12 Wm. Parsons, 2d, \& Co., $\quad 13$

11 Perkins Bros., 10

6 Pettingell \& Cunningham, 5

9 John Pew \& Son, 20

15 Procter, Trask \& Co., 4

7 Joseph O. Procter, 13

14 Rowe \& Jordan, 12

7 Sayward Bros., $\quad 5$

3 Daniel Sayward, 5

5 Shute \& Merchant, 13

3 Smith \& Oakes, $\quad 7$

8 Smith \& Gott, $\quad 17$

20 James A. Stetson, 2

13 George Steele, 11

10 James G. Tarr \& Bro., $\quad 16$

10 Walen \& Allen, 14

7 Leonard Walen, 4

8 John F. Wonson \& Co., 12

5 William C. Wonson, ذ 
Eastern Point, Little Good Harbor Beach, Fresh Water Core, Magnolia, Meeting-house Hill, Coffin's Beach, Wheeler's Point, Annisquam,-all within the bounds of Gloucester; or to Andrews' Point, the northern horn of the Cape, near Pigeon Core ; or to Pebble Stone Beach and Long Beach, on the Massachusetts Bay side of the town of Rockport.

Encircled by the great road already described, is an extensive domain, partly of forest, traversed in every direction by uneven and winding foot-paths; and partly of pasture, with hills and hollows destitute of trees, but strewn with boulders; and with a few swamps, thickly covered with stunted maples and pines, with black alders, and with bushes and ferns. Many of the boulder's all over the hundreds of acres of treeless undulations, are immense; and they are both gray and black with patches and flecks of moss.

Near the centre of this waste, are the cellars of an ancient settlement, now overgrown with grass and weeds, and overrun by grazing cattle and horses. And from its many elevations may be seen the towers and steeples of the city of Gloucester, two or three strips of Massachusetts Bay, some of the roofs of Riverdale and Wheeler's Point, the village of Annisquam at the confluence of Lobster Cove and 'Squam River, the estuary uniting 'Squam River with Ipswich Bay, Flag-staff Ridge, overlooking the River and the Bay, and separating Annisquam from the Bay, Coffin's Beach, directly across the estuary from Annisquam, and the white sand-hills near, and, farther away, the knob called the Loaf, at the Chebacco River termination of the curving beach.

The atmosphere of these breezy elevations of the waste, is the purest under the skies. It is wholesome with the mingled breathings of sea and land.

With this description of the landscape and of the views of the Bays and the River, the reader is in a mood to believe that the old Cape, at any point, is grand and admirable as a summer abiding place. If he yet is in doubt about it, let him spend one heated term of July and August in an actual survey of the region put before his mind in this attempt at painting in words. So will he learn that there is more here than can be pictured by the most ingenious pen. 


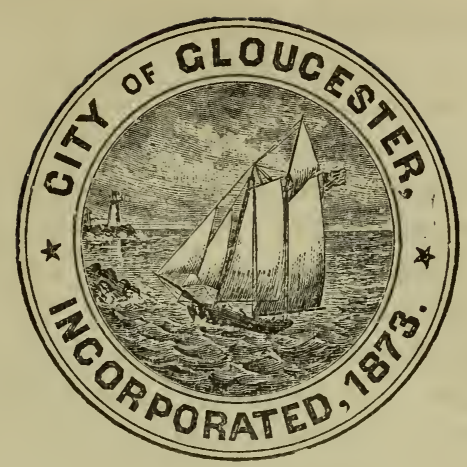

CHAPTER 10.

PUBLIC SCHOOLS.

Among the earliest laws of Massachusetts was one compelling all the towns containing fifty householders to support a public school. Gloucester at quite an carly date contained the requisite number, but they were so far apart that it was deemed well nigh impossible to gather the children into one school; and the town's neglect for several years to comply with the law, was no doubt overlooked. Private or domestic instruction was not lacking, but it was not until 1698 that we find a record of the employment of a public teacher, when, in town-meeting, Thomas Riggs, sen., was chosen to that office, "to have one shilling and sixpence a day during the town's pleasure, and the said Riggs' likeing to carry it on." At that time there was but one Meeting House in town, and there, till 1708, the school was kept. At this date a school-house, twenty-four feet by sixteen, with a height of stud of six feet, was built. This building was erected "to keep a good school in for the godly instruction of" children, and teaching them to read and write good English." Until 1793 the privileges of the public schools of Gloucester seems to have been confined to the boys of the town, the School Committee of 1790 recommending " that provision be made for the education of females, a tender and interesting branch of the community that have been neglected in the public schools of this town."

In 1804, the town increased its facilities for imparting instruction to all its children, by creating eleven school districts, to defray the expenses of schooling in which, it expended the first year $\$ 2,000$. This system continued for forty-five years, the districts increasing in 
number to twenty-three. The inequality of school advantages, poor quality of school-houses and conveniences, and other considerations led to the abolition of the district system in 1849, at which time there were 1672 children between the ages of fire and fifteen years, and the annual expenses of the schools were \$5,562.25. In 1850 the town assumed in its corporate capacity, the sole management of the schools, and has continued it to the present. It involved a large outlay for new school-houses, but it secured uniformity of instruction in all parts of the town, better teachers, and many other advantages. The school expenses, exclusive of cost of buildings, were in $1850, \$ 6,086.19$; in $1860, \$ 13,267.50$; in $1870, \$ 40,510.07$; and for the present year are estimated at $\$ 54,695$. In 1860 the whole number of children in attendance was 2081 ; in 1870 the whole number registered was 3205 ; and in 1876 the estimated number is 3500 .

The schools of Gloucester now occupy twenty-four different buildings, two being rented, and the remainder the property of the city. One High School with six teachers, six Grammar Schools with thilty-one teachers, twelve Primaries with thirty-four teachers, and four Mixed Schools,-in which both Grammar and Primary studies are taught,- -with six teachers, make a total of seventy-seven teachers constantly employed during the school year of forty weeks. A teacher of Drawing and a teacher of Music are also constantly employed. Two or more additional schools are also kept during the winter, for the accommodation of a large number of boys who are engaged in the fisheries in other portions of the year. Winter evening instruction in Free-Hand and Mechanical Drawing is also given to adults. The care of the schools is confided to a Committee, consisting of the Mayor, and nine persons elected by the citizens at large. The supervision of the school work is delegated to a Superintendent, elected by the committee. John W. Allard, A. M., the present Superintendent, was elected in 1873 .

\section{CHURCHES.}

The early Religious Societies in Gloucester were denominated, as was the custom throughout the State, Parishes, and were accurately defined as to their territorial boundaries. No such distinctions now exist, but one Society now retaining its original Parish name, and therefore in speaking of the present Religious Societies in the city, they will, with this one exception, be classified by sects in the order of their age. The original parishes were all of the Orthodox Congregational order. 
Unitarian.-The First Parish, organized in 1642, settled a Unitarian pastor in 1834, and has been a pronounced Unitarian Society since that time. It occupies the House of Worship erected in 1828, on Middle street, on the site of the venerable edifice built in 1738 , and chiefly memorable as having been the target on which the British commander, Linzee, brought the guns of the sloop-of-war Falcon to bear, on the 8th of August, 1775. The present pastor, Rev. Minot G. Gage, was settled over the Society, January, 1870.

Universalist-I. The Independent Christian Society, (the oldest Universalist Society in the United States,) grew out of the labors of the Rev. John Murray, who came to Gloucester in 1774, and remained except during a short period while Chaplain of the Rhode Island Brigade, in the struggle for National Independence, till 1793. Its present House of Worship, the second erected by it, is situated on Middle street, and was built in 1806 . The present pastor, Rev. Richard Eddy, was settled May, 1870.

II. Rer. Ezra Leonard, settled orer the Third Parish in 1804,the Parish having been incorporated in 1728, , became a Universalist in 1811, and with the exception of a few members, his congregation followed him in his new views, and he continued to be their pastor till his death, in 1832. The Meeting House is located in that part of the city best known as Annisquam, and was erected in 1830, the first edifice built by the Society on the same site, in 1728 , being then taken down on account of its age. The present pastor is Rev. Henry C. Leonard, settled in 1876.

III. In 1830 a majority of the Second Parish, incorporated in 1716, became Universalists, and continued to occupy the Meeting House built about the time of the incorporation of the parish, till 1846, when the edifice was abandoned and demolished. The Society have erected, in 1876, a Chapel at West Gloucester, near the junction of the Essex and Coffin's Beach roads. Their present pastor, settled in 1875, is Rev. Elmer F. Pember.

IV. The Universalist Society at Lanesville, for many years a portion of the Annisquam Society, created a separate organization in 1876. Their present place of worship is Village Hall, and their pastor, Rev. Byron G. Russell, was settled in 1875 .

Methodist.-I. Organized in 1825, in the limits of the Fourth Parish, the Society built their first House of Worship on the corner of 'Taylor' and Prospect streets, in 1828. In 1858 they purchased their present church edgifice on Elm street. The present pastor, 
Rer. Albert Gould, was appointed to the charge, by the Conference, in 1875 .

II. That portion of the parent Society left in the Fourth Parish, by the change in place of worship in 1828 , continued to share the services of the pastors sent by Conference to the Society on Prospect street, until 1838; since which time they have been a separate charge. 'Their House of Worship, erected in 1838, is located at Riverdale. 'The present pastor, Rev. Walter Wilkie, was appointed by the Conference in 1876 .

III. In 1871 a Society was organized at Bay View, and a House of Worship erected in 1872. The present pastor, Rer. William B. Toulwin, was appointed by the Conference in 1876 .

Orthodox Congregationalists.-I. A rupture occurred in the First Parish, occasioned by dissatisfaction with the doctrinal views of the pastor, in 1829, which resulted in the formation of the Evangelical Orthodox Church, that year, and of a Society a year later. The House of Worship now occupied by the Society, the second built by them on the same site, was erected at the corner of School and Middle streets, in 1855. The present pastor, Rer. F. B. Makepeace, was settled in 1873 .

II. The North Orthodox Congregational Church, located at Lanesville, was organized in 1831. Their House of Worship, erected in 1828, was enlarged in 1853. Rer. Samuel B. Andrews, their present pastor, was settled in 1867 .

III. The Church connected with the Second Parish, and organized in 1716 , withdrew from the Society, when a majority of the latter changed their theological views, in 1830. A reorganization took place, and a new House of Worship was erected in West Gloucester, on the Essex road, in 1834. Rer. Nathaniel Richardson, the present pastor, was settled in 1874 .

Baptist.-I. 'The Second Baptist Church, (the First having been instituted at Sandy Bay, now the town of Rockport, in 1808,) was organized in 1830. Their House of Worship, the third erected by the Society, and the second on the present site, was built in 1871 , on the corner of Pleasant and Middle streets. Rev. J. Mr. English, the present pastor, was settled in 1875 .

II. A Baptist Chapel was erected at East Gloucester in 1858, and greatly enlarged in 1869. The Church was organized in 1863. The location of the House of Worship is on Chapel street, and the present pastor, Rev. A. Mr. Higgins, was seţtled in 1875 .

Roman Catholic.-I. St. Anne's Church. Mass was first cel- 
ebrated in Gloucester, in January, 1849. In 1855 a Church edifice was consecrated. A new Church edifice, to be constructed of Cape Ann granite, is now being built. It will have a seating capacity of about 1200. Rev. J. J. Healy, pastor, was settled in 1871 ; Rev. Eugene F. McCarthy, assistant, in 1876.

II. St. Joachim's Church. Mass was first celebrated in Lanesville about 1850 . A Church edifice is now being erected. Rev. Thomas Barry of Rockport, pastor since 1869, ofticiates every Sunday morning, at Village Hall.

Episcopalian.-St. John's Church was organized in 1864: The Church edifice, erected in $\mathbf{1 8 6 4}$, is located on Middle street. Rev. James D. Reid, Rector, was settled in 1868.

Swedenborgian.- The First Society of the New Church in Gloucester, was organized in May, 1871. Services every Sunday morning, at the residence of the pastor, Rev. Robert P. Rogers, Washington street, opposite Granite street.

Second Adventists.- Three persons believing in the tenets of this sect, held their first meeting here in 1871. Their present number is forty-two, who hold monthly meetings for preaching, in Hicks' Hall, Western Arenue, and weekly prayer meetings at private residences.

CHARITABLE SOCIETIES.

I. The Gloucester Female Charitable Association was organized in 1834, for the purpose of assisting the poor. Its funds are derived from annual memberships and donations. In 1875 it aided one hundred and twenty-six families.

II. The Gloucester Fishermen's and Seamen's Widows' and Orphans' Aid Society, was organized in 1859 as the Widows' and Orphans' Fund Society, and re-organized in 1865. It is supported by annual memberships, at $\$ 2.00$, life memberships at $\$ 10.00$, and the payment by those engaged in the fisheries of one-fourth of one per cent. on the fishing royages of the year. Last year the amount disbursed for the relief of widows and children of fishermen, and sick and disabled fishermen and seamen, was $\$ 6,722.92$.

III. The Tenement Association for Widows and Orphans, was organized in 1871. Its object is, "To furnish at moderate rate, homes for the widows of our lost Fishermen." It has erected, at a cost of $\$ 7,500$, a building containing ten tenements.

MASONIC.

I. Tyrian Lodge, A. F. and A. Masons, was chartered by the M. IV. Joseph Warren, G. M. of the Continent of America, March 2, A. 
L. 5770. Its regular communications are the first Tuesday of the month at Masonic Hall, Front street.

II. Acacia Lodge. Instituted August 3, A. L. 5865. Regular communications the first Friday of the month at Masonic Hall.

III. William Ferson Royal Arch Chapter. Constituted Nov. 1871. Regular communications first and third Wednesday evenings at Masonic Hall.

ODD FELYOWS.

I. Ocean Lodge, No.91, was instituted Sept. 10, 1845. Meetings Monday evenings at Odd Fellows' Hall, Front street.

II. . Cape Ann Encampment, No. 33. Instituted Nor. \&, 1866. Meet first and third 'Thursdays at Odd Fellows' Hall.

\section{TEMPERANCE ORGANIZATIONS.}

'There are thirteen 'Temperance Societies in Gloucester, viz. : four' Lodges of Good Templars, one Temple of Honor and Temperance, one Catholic 'Temperance Society, and seven Reform Clubs. 'The city also has a fund of $\$ 10,000$, bequeathed some years ago by Mr. George Sanders, a wealthy citizen of Cambridge, whose ancestors were from Gloucester. By the terms of the bequest the income is " to be a permanent salary to be paid to some worthy man who has discretion and zeal for the cause, to be constantly employed as a Missionary in the cause of 'Temperance, in reforming old drunkards and preventing young drunkards, and abolishing as far as possible, the use of intoxicating articles." Mr. John 'T. Knight is the present Temperance Missionary.

\section{MISCELLANEOUS SOCIETIES.}

Grand Army of the Republic. Post 45. Organized Feb., 1868. Meetings Thursday night, at G. A. R. Hall, Front street.

Knights of Pythias. Cape Ann Lodge, No, 55. Organized Nor. 16, 1871. Meets Wednesday evenings, at Lanesville.

The Sawyer Free Library and Gloucester Lyceum Library Association. The Lyceum was organized in 1830. Library added in 1854 . Incorporated 1872. The Library, located on Front street, is open daily, and contains about 4000 volumes.

Young Men's Christian Association. 'This Society was organized in February, 1873. Its Reading Room, No. 58 Front street, is open daily from 8 A. M. to 10 P. M.

The Cape Ann Scientific and Literary Association was organized in 1875 . Its purpose is to cultivate a knowledge of science in general, and particularly to develop the Natural History of Cape Ann. It meets at Grand Army Hall on the second and fourth Monday evening in each month.

Cape Ann Horticultural Society. Organized February, 1866, and holds its annual mecting in February. 


\section{THE \\ CELEBRATED CENTURY SERMON, \\ OF THE}

REV. NATHANAEL HOWE

OF

HOPKINTON, MASS.

TOGETHER WITH

A MEMOIR OF HIS LIFE,

BY ELIAS NASON, A. M. 



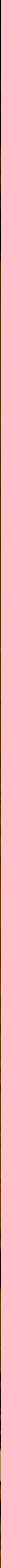

